Historic, Archive Document

Do not assume content reflects current scientific knowledge, policies, or practices. 


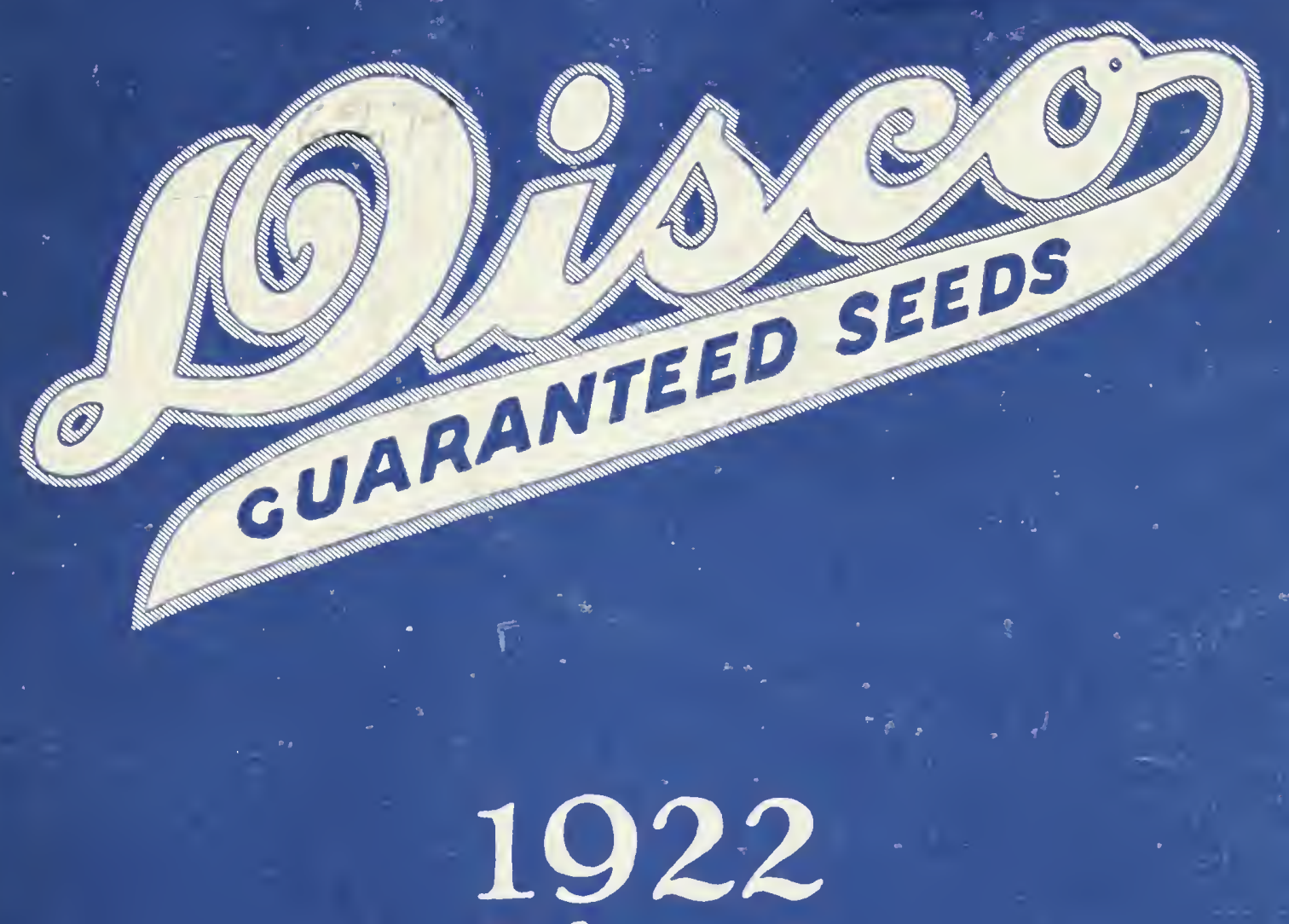

.

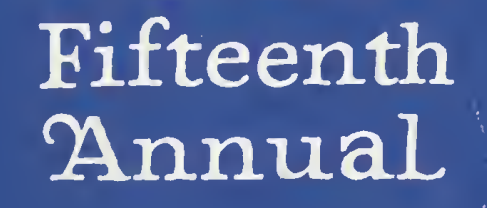

DAKOTA IVPROUED SEA CO. BREEDERS \& GROWERS OF PEDIGREED FARM \& GARDEN SEEDS MITCHELL, SOUTH DAKOTA 


\section{The Home of}

Located as

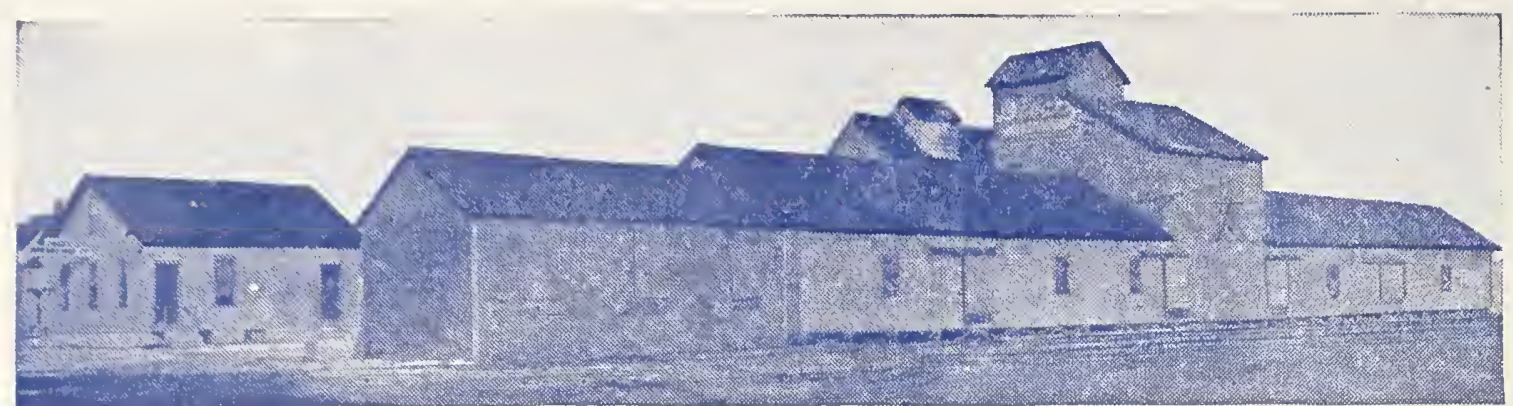

we are, on the railroad t r a c k, not only means lower rent al, but reduces o u o p e rating ex p e n ses, which we in turil pass on to our cus tomers, enahling us to supply highes t quality guaranteed seeds at fair prices.

See the Disco Guarantee on the inside back cover of this book

OFFICERS OF THE COMPANY

W. S. HILL, President RICHARD BURN, Vice-president other directors

S. E. MORRIS

\section{W. DERR \\ A. E. DEAN \\ Bank References}

Western National, Mitchell Midland National, Minneapolis National Bank of the Republic, Chicago

\section{DISCO'S ADVICE}

Freight rates are so high and so far out of proportion to the value of Farm and Garden products, that it behooves evervone of us to put on our thinking cap and evolve some plans whereby we can produce to the limit of what we need for our own use on the farm, or if we are condemned to live in the city or town, then on the space we have available. In this very direction may we suggest that you extend materially the quantity and the number of varieties of Vegetables that you will grow in 1922. Just here is where we can help you, we can give you just the right seed and give you instructions how to proceed. We did this very thing ourselves last year. On a vacant lot near our office, we produced enough vegetables for several families and had some to give away besides, to those who did not think of it. We got lots of healthy exercise and enjoyment out of it, too.

We were pleased to be able to announce a year ago our re-introduction of Garden Seeds, both Vegetable and Flowers, and we were more than satisfied with the excellent reception which our seeds received from our many customers. That the results obtained were gratifying, was amply evidenced by the reports which have come to us from North. South, East and West.

\section{THE SLOGAN FOR THE FARM IN 1922}

Increase the acreage of Alfalfa, Clover, Timothy and other Pasture and Hay crops, reduce the acreage of Corn, but plant Pedigree Seed Corn so as to increase the crop from the reduced acreage. This is the key to the situation.

We specialize in Pedigreed and Registered Alfalfa Seed, Pedigreed Seed Corn, and other seeds for the Farm and Garden. Write us for advice and information.

Professor W. A. Wheeler says, "There is more money in Alfalfa and Corn for live stock than in any other single crop or combination of crops in the world."

\section{INDEX}

Page

Alfalfa $\ldots \ldots \ldots \ldots . . .4,5,6$

Barley ............. 16

Beans, Navy .............. 13

Beans, Soya ........... 13

Brome Grass ......... 11

Buckwheat .........12

Canadian Blue Grass... 11 Canes, ............. 10 Carrots, Field ........ 15 Clovers ............ 3, 7 Corn .......... Corn Testers...Back Cover Crested Dogstail .......11 Cultivators ....Bäk Cover Feterita .............. 10 Fertilizers, etc. Back Cover Field Carrots ......... 15 Field Peas .............. 13 Flax ............. 16 Flower seeds,

Alphabetical......35 to 48 Grasses ............. 11

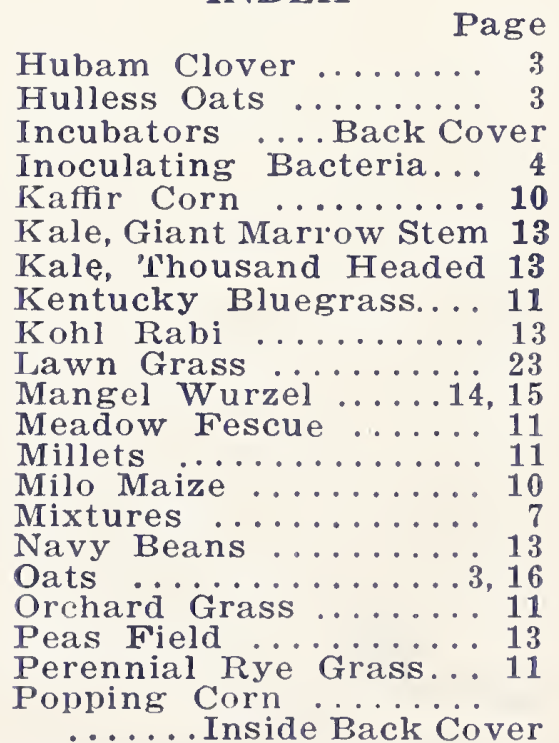

Page

Page

Potatoes ...........26

Poultry Supplies...... ....... Inside Back Cover

Rape, Dwarf Essex.... 12

Red Top ...........11

Ruby Wheat ...........

Rutabaga ........... 14

Rye ............ 16

Seed Sowers....Back Cover

Speltz ............. 16

Sudan Grass .......... 13

Sugar Beets ......... 15

Sunflower, Russian

Giant .............. 12 Swede Turnip ......... 14

Sweet Peas ..........35 Thousand Headed Kale. 13 Timothy ............ 11 Vegetable Seeds,

Alphabetical....17 to 34 western Rye Grass.... 11 Wheat ............. 16 


\section{Order Sheet}

Date.

Dakota Improved Seed Co., Mitchell, South Dakota.

Gentlemen: Please send the following seeds subject to the guarantee and conditions of sale given in the DISCOSeed Book.

Name

P. 0 .

Mr., Mrs. or Miss. Please write plainly

\section{County}

State

R. D., P. O. Box or Street No.

By

State here if wanted by freight, express or parcel-post

Nearest Railway Station If different from $\mathrm{P}$. 0 .

Is there a freight agent at your railroad station?

If there is no freight agent at your shipping point, money must be sent with order to prepay the freight charges

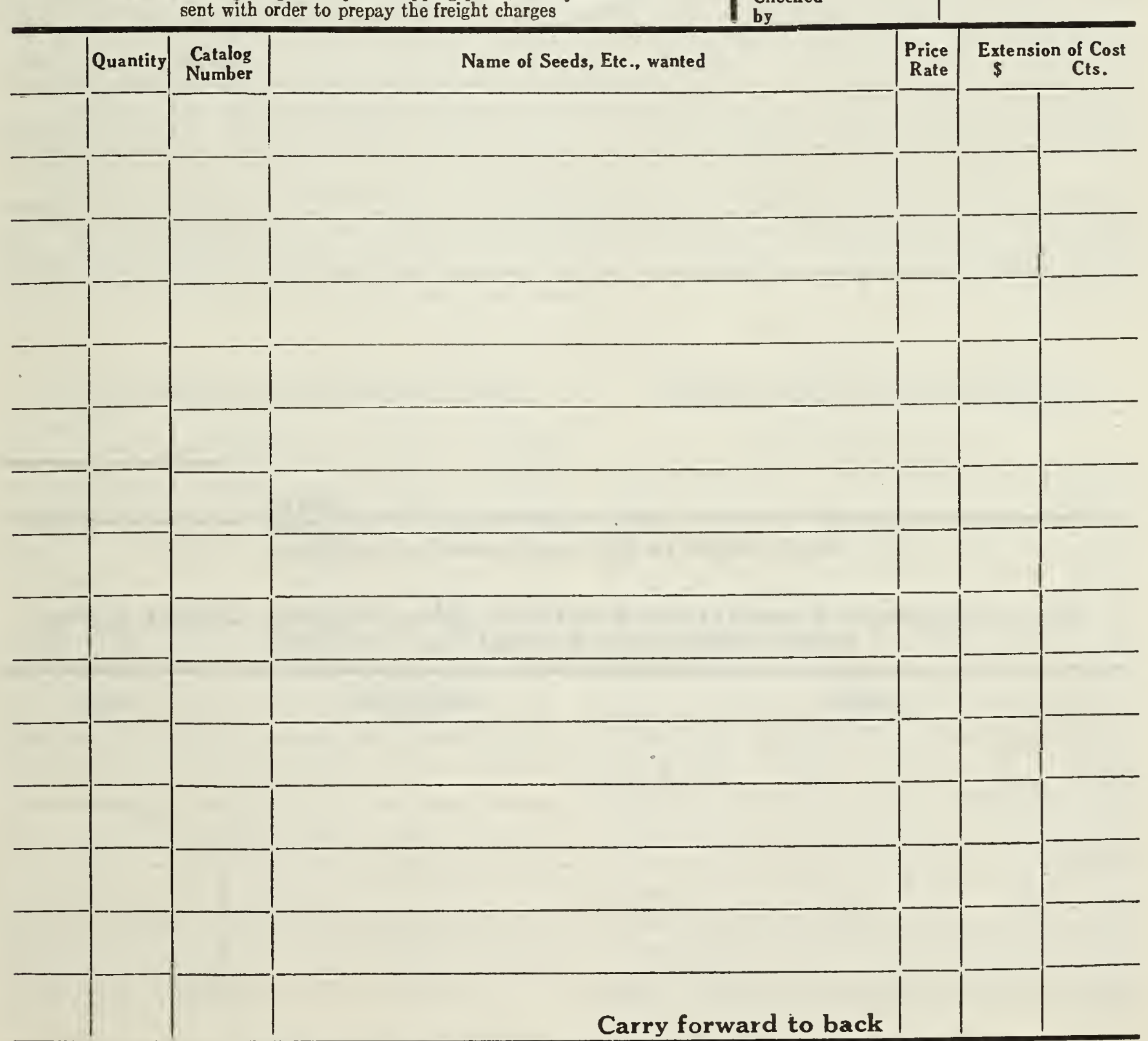




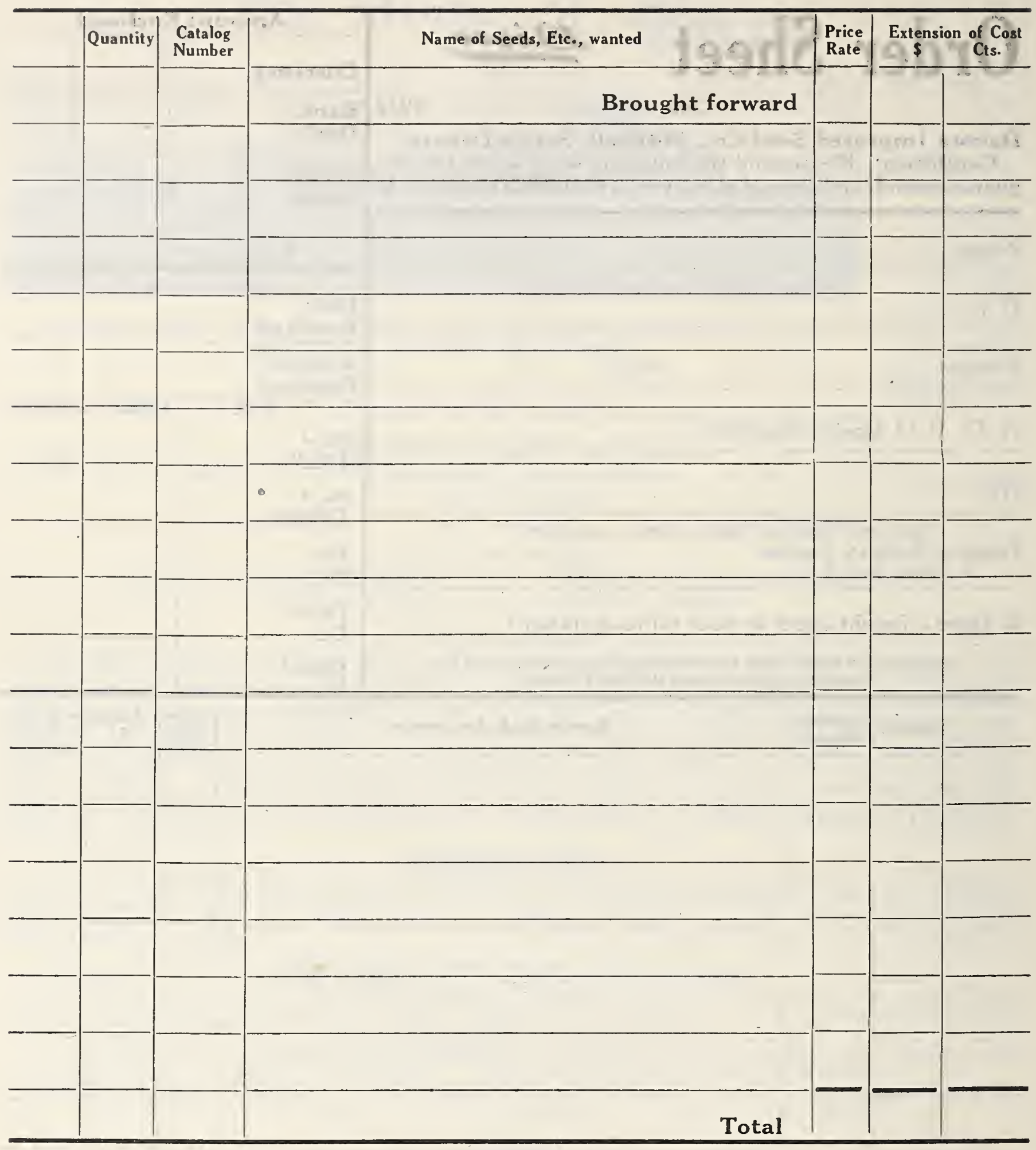

Don't forget to sign your name and address

We will consider it a special favor if you write below the names of some of your friends who you think would like our catalog 


\section{New and Noteworthy Introductions for the Farm}

\section{Hubam Sweet Clover \\ The New Annual Variety}

No recent introduction in plant life in the Agricultural World, has received so much publicity and been heralded, metaphorically speaking, by such a fan fare of trumpets. And those who blew the trumpets have been big nien too, men whose reputation is such that they could not afford to jeopardize their position and authority by getting behind a thing which would not stand the acid test.

We ourselves have been unfortunate in our trials of this new Clover. Every time we tried it, some accident occurred, and the trial was rendered abortive.

With the eulogies it has received from such representative men, we feel justified in introducing this plant to our customers, and advising a trial. While we do not feel like endorsing all that has been claimed for it, we take the same stand on the matter as ex-Governor Lowden of Illinois, who is reported to have expressed himself thus: "If reports of Hubam are one-half true, it is the most revolutionary crop and means more to agriculture in the corn belt than any one thing that has been discovered in my life time."

Hubam is a very vigorous, rapid growing annual Sweet Clover. Like many another wonderful discovery, it was found in some respects by accident, as it first attracted attention when found growing in a mixture of seed at the Iowa Station in 1916 . While we say it was discovered by accident, it must be borne in mind that behind the so-called accident, was the genius of the discoverer, H. D. Hughes. The average individual would probably never have noticed the phenomena, viz; a plant of White Blossom Sweet

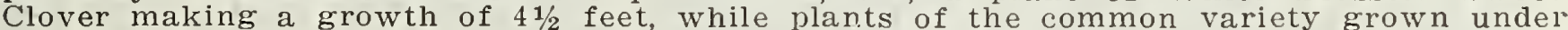
the same conditions, almost side by side, made a growth of 14 inches. "Great trees from little Acorns grow," and the keen observant trained eye and mind, will notice something. which the ordinary traveler along life's highway passes unobserved, the discovery of which metaphorically speaking shakes the universe.

As we have said before, we do not doubt but that this is a wonderful plant.and has a great future, but we doubt whether or not it will supplant the common variety or replace all other forage plants, as some have boldly asserted almost suggesting that it would cover the land, even as the incoming tide takes possession of the shore.

We advise our customers to buy a few pounds and sow it much as they have ordinarily done the biennial variety, perhaps not quite so thick, as it grows quicker. Watch its performance carefully and see if you think it will fulfill all that has been claimed for it, so far as you are concerned. If you are pleased with it, then you can buy more of it next year. It will be lots cheaper then, as so many are saving seed. That's just what we would do if we were in your place.

\section{New Disco 22 Hulless Oats}

We are glad to be able to offer a few of these Oats this Spring. We are not going to have as many as we thought. It very often happens, when you are very anxious to save all you can of some particular crop, that a series of unexpected misfortunes seem to beset you, and it certainly worked that way with our different crops of this wonderful new Oat. We had three different lots we were depending upon. The first was dried out, and they were not worth harvesting. The second, our grower in his anxiety, sowed them in a very rich piece of ground, but unfortunately the weeds got ahead of them and we only got a quarter of a crop. In the third case, our grower did not get them threshed before the snow came, and they were rendered practically useless for seed.

We showed these Oats at the Corn Palace in Mitchell, and Hog Breeders who saw them were certainly delighted. Remember these Oats grow just like ordinary Oats, but they thresh cut without any hulls. When threshed they weigh over 50 pounds to the bushel, and the average yield is 35 bushels per acre. For young pigs and chickens they are the best feed you can imagine. They also make a superior Oatmeal for table use.

\section{New Ruby Wheat}

\section{Bald Spring Variety}

The fact that this Wheat was bred, and first introduced by Dr. Chas. E. Saunders, The Dominion Cerealist, Ottawa, Canada. who is also the Breeder of Marquis and Early Red Fife, as well as many other excellent varieties, is sufficient evidence that it must possess merit. Knowing the disappointment that many of our customers were experiencing with Marquis and other similar Spring Wheats, owing to their tendency to rust, we made extensive research to find a variety which would be of as good milling qualities, a good cropper, sufficiently early and rust resistant to be superior in this respect to the varieties at present being grown. Our choice was New Ruby. We tried it out in several places in the State, and while last year was not a good season to try out any Spring Wheat, nevertheless, we are satisfied that we have gotten a Wheat which will again put Spring Wheats on the map in South Dakota. We imported seed direct from Canada last Spring, from a reliable grower. We had it grown here for us by careful farmers, and consequently have some very nice home grown seed of this excellent new variety to offer. It is ten days earlier than Marquis. 


\section{Alfalfa Is Our Specialty}

The Selection, Breeding and Registration Systems inaugurated by Professor W. A. Wheeler in connection with the Disco Alfalfas, is unique and without a parallel in commerce today. The main thing of course is that they have made good, and are giving ynbounded satisfaction wherever they nave been tried out. Not only do they withstand winter killing, which is such a frequent source of failure in many districts, but they have been found to withstand other adverse factors as well, such as natural vegetation, like Foxtail and Crab Grass which so often menace an Alfalfa crop, high water level, etc.

We have a very careful record compiled, as to the best types for certain districts and conditions, and can advise you intelligently what to use. No other Seed institution, so far as we know, has handled Alfalfa in such a manner so as to render this service to iheir clients.

You are not taking chances when you use the variety of Disco Alfalfa recommended for your particular requirements, as they have behind them years of successful results. You will find that they will give more permanent fields, will pasture more stock for a longer period of time, will yield more cuttings per year, and give a heavier weight of hay per acre than ordinary Alfalfa.

With no immediate prospect of materially increased prices, the only reasonable solution to enable one to break even is to produce the maximum crop per acre with the minimum of labor.

\section{DISCO ALFALFA WILL HELP YOU DO THIS}

Now is an opportune time to make a trial, our prices are clear down to bed rock. Not much, if anything higher than ordinary Alfalfa. Our crops were good and we want everyone interested to try them out. One trial will be sufficient to convince you. They will surely speak for themselves in no uncertain manner.

\section{Disco Alfalfas are the most economical to use, producing as they do, a stronger} thickly as the ordinary Alfalfa. will give excellent results.

In any case price is a poor basis on which to judge. Alfalfa Seed. The cost of the seed is easily the smallest item in the establishing of a profitable Alfalfa field on any farm. The value of the land itself, and the cost of preparing are the items that count, and they remain the same no matter what seed you use. Even a very superficial study of the question will reveal that the real question to determine is, "what is the best seed to use," the difference in actual cost of seeding per acre between the best and the poorest is at the most infinitesimal, and even only slightly improved results will more than cover the difference the first year.

An Alfalfa patch should be like a Tree, handed down from father to son. Some of the fields from which we get our seed have been continuously producing for thirty years.

Too often in the past Alfalfa has simply meant Alfalfa, no discrimination between suitable or unsuitable selections being considered. where.

Disco Alfalfa has become a household word with successful Alfalfa growers every-

When you buy Disco Alfalfa you are buying the best. The best is always the cheapest in the end.

\section{Dakota Grown Common} Alfalfas For the sake of our customers who do not care to pay the price of either Registered or Pedigreed Seed, we always carry a choice stock of the common variety produced on selected fields in South Dakota, of undoubted hardiness.

Our splendid location, right in the heart of the very best growing district and our constant close touch with growing crops, places us in a unique position to select the very finest stocks that the country produces. These stocks are brought direct from the farms where they have been grown, to our own up-to-date Cleaning Plant, and from there distributed by us all over the continent. This enables us not only to give the very finest possible seed, but we are alsn in a position to supply choice seed at a remarkably low price.
Inoculation-The simplest way is to inoculate the seed, provided that a reliable and properly prepared culture is used. There is no doubt whatever that when sowing Alfalfa, particularly on new land, that not only is a better stand obtained, but plants of a hardier type are produced by inoculating, and in view of the very nomi- nal cost to inoculate, it seems almost foolish to take any chances.

We can supply an excellent pure culture, which is put up ready for use by a prominent bacteriologist, and simple yet speciflc instructions are supplied, enabling the merest novice to successfully prepare the seed in a simple and perfect manner. 


\section{Alfalfa Is One of Nature's Choicest Gifts}

\section{Alfalfa the Nonpareil of Fodder Plants}

Disco-Baltic This variety of the falfa was selected many years ago by Mr. Wheeler, and being found growing near a village named Baltic, he felt that it was fitting that the variety be given this name. In describing this new type, the writer of Bulletin No. 757, U. S. Department of Agriculture, says: "While the Baltic differs slightly from the Grimm, in some minor details, the two are so similar that it is seldom possible to distinguish one from the other. This variety is recommended for sections where the ordinary strains suffer considerable loss through winter-killing."

We, as already stated, are the promoters and breeders of Baltic Alfalfa, and it goes without saying, therefore, that to be absolutely sure of getting the right type, it is desirable that you place your order with us. If you do, you are certainly circumventing any possibility of disappointment and are in the most practical way insuring success.

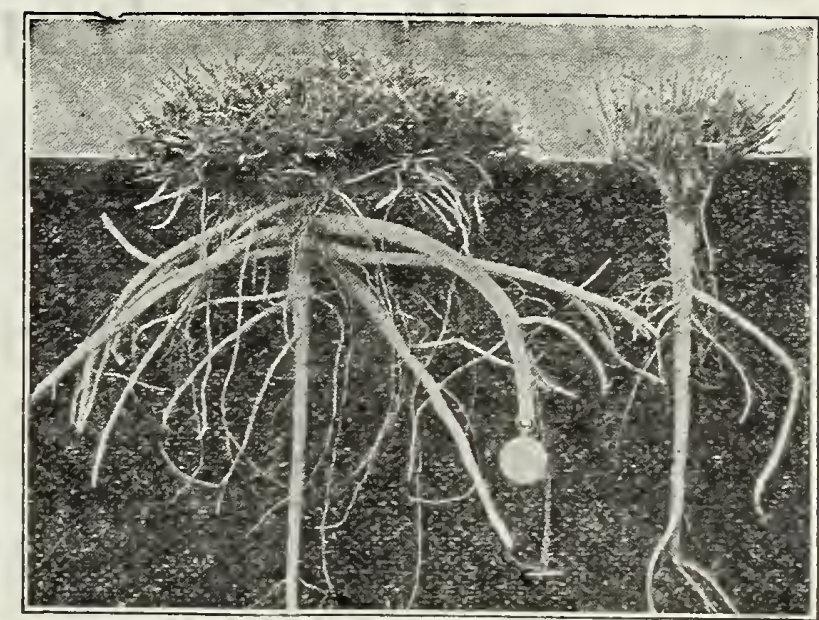

Representative plants of the Hardy and Non-Hardy tyre of crowns of four-year-old alfalfa taken from the same nursery, grown as single plants under the same conditions. The plant on the right, the common Southern tyree the plant on the left, a fair sample of Baltic alfalfa, a variety found growing near the little town of Baltic, So. Dakota. (Bul.181, Col. Ag. Exp. Sta.) Baltic Alfalfa has fulfiled every claimim we have made gor it and has more

Read these conclusive tests, made under totally different conditions, both geographically and climatically.

Comparative Yield of Alfalfa Varieties at Newell, S. D.

\begin{tabular}{|c|c|c|c|c|c|c|c|c|}
\hline \multirow[t]{2}{*}{ Variety } & \multicolumn{3}{|c|}{$\begin{array}{l}\text { Seed-Pounds } \\
\text { Per Acre (1) }\end{array}$} & \multirow[t]{2}{*}{ Total } & \multicolumn{3}{|c|}{$\begin{array}{l}\text { Hay-Pounds } \\
\text { Per Acre (2) }\end{array}$} & \multirow{2}{*}{$\begin{array}{c}\text { Total } \\
\text { Hay-Tons } \\
\text { Per Acre }\end{array}$} \\
\hline & 1914 & 1915 & 1916 & & 1914 & 1915 & 1916 & \\
\hline 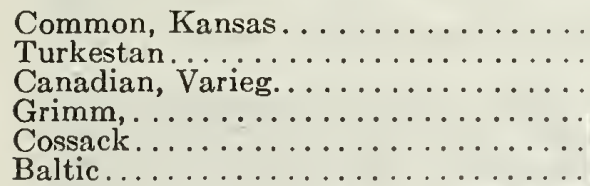 & $\begin{array}{l}142 \\
166 \\
167 \\
110 \\
186\end{array}$ & $\begin{array}{r}18 \\
15 \\
60 \\
98 \\
45 \\
102\end{array}$ & $\begin{array}{r}78 \\
90 \\
80 \\
88 \\
70 \\
142\end{array}$ & $\begin{array}{l}238 \\
105 \\
306 \\
353 \\
225 \\
430\end{array}$ & $\begin{array}{l}782 \\
900 \\
894 \\
795 \\
994\end{array}$ & $\begin{array}{l}5850 \\
5830 \\
6670 \\
6570 \\
7030 \\
7550\end{array}$ & $\begin{array}{l}2395 \\
2535 \\
2490 \\
2585 \\
2650 \\
2880\end{array}$ & $\begin{array}{l}4.5 \\
4.2 \\
5.0 \\
5.0 \\
5.2 \\
5.7\end{array}$ \\
\hline
\end{tabular}

(1) Yield of 1 plat of each variety each year.

(2) Average yield of 3 plats of each variety each year. Coninative Yield of Alfalfa Varieties at Mrandon, Man., Canada

\begin{tabular}{|c|c|c|c|c|c|c|c|c|}
\hline \multirow{2}{*}{ Variety } & \multicolumn{3}{|c|}{ First Cutting } & \multicolumn{3}{|c|}{ Second Cutting } & \multirow{2}{*}{\multicolumn{2}{|c|}{$\begin{array}{c}\text { Total Yield } \\
\text { of Hay } \\
\text { per Acre }\end{array}$}} \\
\hline & Date & Yield & Acre & Date & Yield & Acre & & \\
\hline $\begin{array}{l}\text { Baltic Alfalfa ...... } \\
\text { Cossack Alfalfa .... } \\
\text { Turkestan Alfalfa... } \\
\text { Grimm Alfalfa.... } \\
\text { Liscomb Alfalfa.... } \\
\text { Montana Alfalfa... }\end{array}$ & $\begin{array}{l}\text { June 28, } 1917 \\
\text { June 28, } 1917 \\
\text { June 28, } 1917 \\
\text { June 28, } 1917 \\
\text { June 28, } 1917 \\
\text { June 28, } 1917\end{array}$ & $\begin{array}{c}\text { Tons } \\
2 \\
1 \\
2 \\
1 \\
1 \\
1\end{array}$ & $\begin{array}{r}\text { Lbs. } \\
40 \\
1840 \\
160 \\
1440 \\
1200 \\
1120 \\
\end{array}$ & $\begin{array}{l}\text { July } 28,1917 \\
\text { July } 28,1917 \\
\text { July 28, } 1917 \\
\text { July 28, } 1917 \\
\text { July 28, } 1917 \\
\text { July } 28,1917 \\
\end{array}$ & $\begin{array}{l}\text { Tons } \\
\cdots \cdots \cdots \\
\cdots \cdots \cdots \\
\cdots \cdots \cdots \\
\cdots \cdots \cdots \\
\cdots \cdots \cdots \\
\end{array}$ & $\begin{array}{l}\text { Lbs. } \\
1580 \\
1680 \\
1340 \\
1820 \\
1440 \\
1200\end{array}$ & $\begin{array}{c}\text { Tons } \\
2 \\
2 \\
2 \\
2 \\
2 \\
2\end{array}$ & $\begin{array}{r}\text { Lbs. } \\
1620 \\
1520 \\
1500 \\
1260 \\
640 \\
320\end{array}$ \\
\hline
\end{tabular}

These tests only admit of one conclusion, viz.; that Baltic is the best all round
variety to grow, and at the comparatively low price which we are able to sell this year, in view of our splendid crop, no one interested in having the best Alfalfa to be had should hesitate one minute, but order today. All Our Alfalfas are Dakota Grown

\section{Baltic Type}

Disco No. 11-G has been proven by hardiest of the hardy. Excellent yields and perfect stands have been obtained when no other variety could previously be grown for any length of time. Its drought resistance is phenomenal; recovers remarkably quick after cutting; yields an abundance of leaf $y$ hay and is also a good seed cropper. Supply limited.

Disco No. 19-A from the Grimm type, plant in a remarkablexcels its parent lact from Alfalfa Nursery. The plants showed characteristics which distinguished them from all others. These plants were isolated and the seed carefully saved. It has been grown year after year producing an abundant seed crop, enabling us to distribute the produce over a very extended territory and we have very gratifying reports as to its success.

\section{Disco Grimm we need not elab-} tory of Grimm Alfalfa, it has been so often referred to that it is known almost everywhere where Alfalfa is spoken of. Suffice it to say that our stock has been grown under the most exacting conditions, so that its hardiness and its well known resistance to winter-killing have not only been maintained, but by constant selection have been very much improved.

Revort from F. C. Sulth, County Agricultural Asent, ivestport, N. Y.-The Disco $19 \mathrm{~A}$ and Baltic are running neck and neck. The Baltic averaging for the two years $343 / 100$ tons per acre, two cuttings per year as compared with the Common Alfalfa yielding $233 / 100$ per acre. The Grimm was slightly below the Baltic, averaging $294 / 100$

I question whether in our test the results indicate any difference in $19 \mathrm{~A}$ over the Baltic. 


\section{Greater Profits from Registered Alfalfas}

It is just as important to know the kind of alfalfa you plant as it is to know the kind or variety of corn, wheat, oats or any other farm crop-in fact it is more important because a single seeding of alfalfa lasts for several years (if you plant Disco Registered Alfalfa Seed) while grains are merely one-year crops. Neither you nor any other up-to-date farmer would go to your neighbor or your seedsman and buy just oats for seed. Most certainly you wouldn't. Instead you would ask for Swedish Select or Sixty-Day oats or some other variety of registered seed that you knew absolutely was the best seed for your purpose that money could buy.

Apply the same line of reasoning to your alfalfa seed. Instead of buying just alfalfa seed, buy Disco No. 28 or Disco No. 38 or any other Disco registered number, and thus be able to know just what you are getting and be able to secure more seed of the same number of its equivalent later.

\section{Costs Less Per Acre Than Ordinary Alfalfas}

A seeding of ten to twelve pounds per acre of Disco Registered Alfalfa Seed invariably gives greater returns than fifteen to twenty pounds of ordinary commercial alfalfa. The cost per pound of seed may be more but the lighter seeding required and the greater returns from Disco Registered Seed make your profits nearly double.

No up-to-date farmer who wants to make more money will buy just ordinary alfalfa seed or just Western, American, Turkestan, Montana or Kansas seed, but will buy Disco Pegistered Alfalfa Seed recorded under the system approved by the best Agricultural Experiment Stations and alfalfa authorities in the country.

Hardiness and the correct type of Alfalfa plant are most important factors, whether you live in the Cotton Belt, the Corn Belt or the Wheat Belt.

\section{Disco Registered Alfalfa}

The "DISCO Registration System" enables us to trace each individual strain of Alfalfa to a definite single origin, and if in your jnitial experimenting you try several different types and find that one particular type seems to suit your requirements infinitely better than others, you have only to advise us of the particular type this was and we can supply you with seed saved from exactly the same plants. We believe that this system, which we have adopted, places us in a unique position to satisfy.

The following registered seeds are offered for this season, with brief descriptions of each stock. The supply of good seeds this year is better than for some time.

Disco No, 26-Believed to be of Turkestan origin; has been grown in the northern half of Meade and southern half of Perkins Counties, South Dakota, for the past sixteen years. This has proved to be a very popular strain.

Disco No. 28-This, in our opinion, heads the list of registered stocks; has been grown in southern Meade and Pennington Counties, South Dakota, for over thirty years, under the most adverse conditions and has persisted year after year and withstood the severe cold and drought. We find that those who have once used Disco 28 , seem to get the habit of "wanting no other," and, as the stock is somewhat limited, to avoid disappointment, we strongly urge the desirability of ordering early.

Disco No. 38 -This strain runs Disco 28 very closely in popularity. It has been grown in vestern Meade and southern Butte Counties for over twenty-five years. Iarge quantities of this seed are distributed by us every year in Oregon and other western states, where it gives extraordinary rood satisfaction in the drier areas without irrigation. The seed stock is an excellent quality.

Disco No. $79-A$ native of the Black Hills region, having a continuous record of over twenty years; very popular; produces a heavy crop of hay and is also a great producer of seed.

Disco No. 80-Grown in Jones and Lyman Counties, South Dakota. In this type the drought and cold resistant characteristics have been developed to a marked degree. We can recommend this strain with perfect confidence.

Dakota 12-A native of the Black Hills district, which has given excellent results to many of our customers.

\section{The Testimony of the User}

Cirvin, Sask, Canada, March 28,1921

The Alfalfa seed I received from you has proved perfectly satisfactory. Sixty acres seeded at Girvin, Sask., four years ago is still doing well. I am recommending it to others.

Stanbury, Mo., March 21, 1921.

Please give me price on Disco 28. Your northern grown seed has stood the winter in this section and most Kansas and Nebraska seed have been winter killed. Some side by side in my field have failed while your seed went through the winter fine. Our ground heaves when the nights are cold and the days warm as has been the case this open winter.

Howard City, Mich., April 28, 1921.

The Alfalfa seed I got from you was the best I ever bought anywhere. I seeded five acres last spring with your Disco 28 and got a fine stand and am very proud of it.

Spray Ranch, Salida, Colo., Feb. 24, 1921.

In the spring of 1915 or 1916 my husband sent to you from Baltimore, Md., for some pedigreed Alfalfa for the ranch here in Colorado and you shipped it directly here. The tenant neglected it but still it grew well enough for us to see it is better than most of the Alfalfa on the place as it comes up so early, and grows so fast we can get three cuttings from it which is unusual for this high valley. I want some of the same sort of seed we got then if possible. Please send me recent catalog.

This was traced from our records to be Disco 79 and we were able to supply our customer with exactly the same seed. This shows the value of the Disco Registration System. 


\section{Lisco Guaranteed Clovers}

\section{Highest Grade, Thoroughly Recleaned}

SWEET CLOVER

White Blossom-(Melilotus alba). Until a few years ago this clover was not looked upon with any great degree of favor.

Here and there, there were those who had tested its value and persistently advocated its usefulness. Today the value of the plant is freely acknowledged by all progressive farmers. We cannot too highly emphasize its importance both for pasture and for hay, while as a soil builder and renovator it has no equal. We feel that it is desirable to lay emphasis on the fact that as a preparation for Alfalfa it is second to none. That is to say, where Alfalfa has been found difficult to grow the experience has been that by growing Sweet Clover for, say a couple of years, the land becomes inoculated with nitrogen-gathering bacteria and it is usually then found that Alfalfa can be grown without difficulty. White Blosson Sweet Clover is a biennial, lasts but two years unless the seed crop at the end of the second year is allowed to form and scatter. This adapts Sweet Clover very nicely into a crop rotation and also insures its easy elimination if it is desired to discontinue growing. The stock of seed we offer is of excellent quality, carefully re-cleaned over our high-grade machinery, scarified by our own scarifying machine, of high vitality and we believe we are offering the best value on the market.

DISCO SELECTED MIXTURES for various purposes.

DISC0 Permanent Pasture Mixtures-a. For high and dry land. b. For good rich land, neither too wet nor too dry. Blends of the most desirable grasses in proper proportions with the object of insuring not only abundant pasture but maintaining same for the longest possible time.

DISCo Permanent Meadow Mixtures-c. For high and dry land. d. For good land, neither too wet nor too dry. e. For moist and wet land. Blended in such proportion as will insure the heaviest possible crop of good quality hay.

Timnthy and Alsike Mixed-The mixture we offer of these two desirable grasses is blended in such proportions as years of experience have shown to give the most desirable combination.
Yellow Blossom-(Melilotus officinalis). Belongs to the same type as the White Blossom, excepting that the flowers are Yellow.

It is claimed that it yields earlier and produces a finer quality of hay. It will not produce as heavy a tonnage as the White, as it is shorter in growth, but for early use it is superior to the White.

Medium Red Clover-Regarded as the most valuable of the Clover family; a dependable all-round variety. Not only does it produce a heavy weight per acre, but richness of the roots in nitrogen gathering bacteria means added fertility to the soil.

Mammoth Red Clover-Coarser and stronger growing than Medium Red. Well adapted for hay, if cut early, but is mostly used as a pasture and for fertilizing.

Alsike or Swedish CIover-Produces the finest quality of clover hay; unusually hardy, and well adapted for pasture. Thrives best on low and moist lands and is particularly well adapted for mixing with Timothy, as it will grow under similar conditions and can be cured well if grown in this manner.

White or Ilutch Clover-A dwarf, close growing variety, in demand for lawns.

Timothy and Medium Red Clover Mixed - This also makes a very useful mixture for temporary meadow, and gives a heavy crop of excellent hay of high feeding value.

Annual Hog Pasture Mixture - Some years ago we were asked to make up a special mixture by some of our customers that would be suitable for seeding down in odd places which would otherwise be treated as waste land, for the purpose of providing a quick-growing annual hog pasture, and after careful research and several experiments we prepared a mixture which has been giving wonderful results. This mixture may be sown i? any waste patches or on pastures where the grass has become thin, may be sown about corn-planting time, sowing from thirty-five to fifty pounds per acre. Hogs thrive on this much better than they do on any single variety as it gives them just that change of diet that.all animals require.

For special prices see colored sheet 
Dakota Improved Seed Co., Mitchell, S. D.

\section{Disces Pedigreed Seed Corn}

Dakota Grown, Early, Hardy, Well Matured

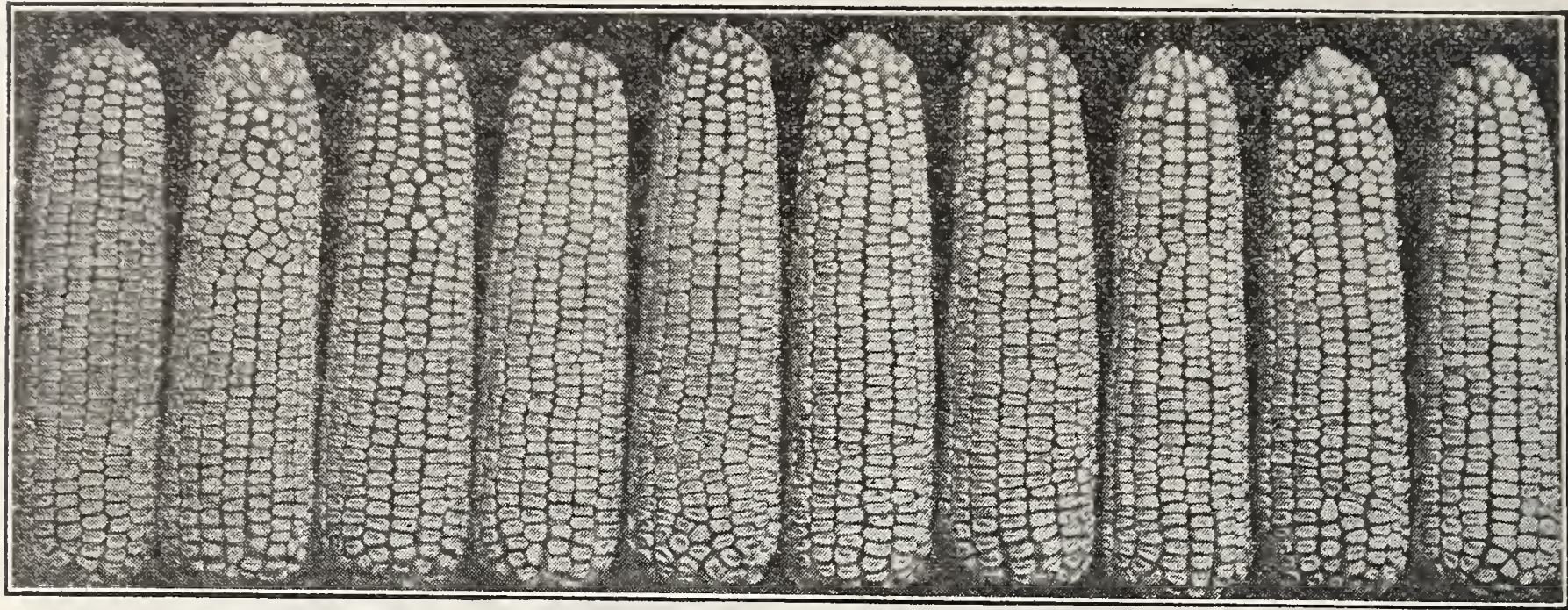

Riverview Special Yellow Dent

Located as we are in the best Seed Corn growing district in South Dakota with our own spacious and up-to-date drying racks and bins and latest type of shelling machinery. Giving personal attention to our growing stocks we are ideally situated to give Seed Corn service. Our stocks being grown under rigorous climatic conditins, yet rarely being affected by frost, enables us to offer varieties of Seed Corn well adapted to the Northwest and Canada. Like all our seeds, Corn is sold on our absolute money back guarantee.

Get a copy of our Booklet, "Corn Culture in the Northwest" 10c. Free with orders on request.

Riverview Special-Yellow Dent. The vely best $90-$ day yellow dent at present on the market. Year by year it enhances its popularity and the number of users is extended so that it is grown with marked success and satisfaction all over the Northwest. It was developed by us more particularly because of its hardy nature, while at the same time it gives a good ear with a very high-shelling percentage. The ears will average eight and one-half inches in length, with a girth of seven inches, with from sixteen to eighteen rows well carried out at butt and tip. The color is a rich yellow and the grain is unusually deep, of smooth handsome appearance. The ears are well formed, uniform size and of moderately strong shank. It has a very leafy growth and attains a height of from seven and one-half to eight feet, and usually yields from forty to sixty bushels per acre. Riverview special is also well adapted for drilling in for use for ensilage or fodder. We strongly recommend this.

Iinnesota 13-Yellow Dent. We aim to retain the earliness of the original type by regularly obtaining our seed for our own planting directly from the Minnesota Experiment Station. This enables us to offer high class seed. Our stock of Minnesota 13 is unusually good this season, and we recommend it with confidence.

DISCO Early Murdock-Yellow Dent. The kernel is deep. One of the earliest of the deep kerneled types, well fixed and is rapidly leaping into popular favor. Will grow

to a height of from six to eight feet, has a stiff stalk which stands up well. Ears are borne well up on the stalk so that they are easily husked.

DISCO Pride-Yellow Dent. A very early variety of corn. Especially well adapted to the northern part of South Dakota. North Dakota, Montana and Manitoba, Canada. The strong features of DISCo Pride are earliness, deep kernel, small cob and its ability to resist dry weather.

Our stock of seed was grown in Hanson County, South Dakota, and is very good quality.

Pride of the North-85-Day Yellow Dent Bright red cob, ears medium size with deep kernel. Many of the stalks have two good ears. We introduced this variety for the first time last year and our customers who used it are well pleased with the results. Well adapted for North Dakota and northern Minnesota.

Wimples Yellow Dent. This variety is very popular in many districts where it seems to excel all others and we recommend it for trial where other varieties already tried have not been entirely satisfactory. It belongs to the early type of yellow dent, especially adapted for the northwest. The size of the ear is surprising, averaging from nine to nine and onehalf inches in length and from six to six and one-half inches in girth containing from sixteen to eighteen rows. One of the best short season varieties on the market.

Disco,

Mitchell, South Dakota.

Gentlemen:

I want to give you a word of encouragement on your Wimples Yellow Dent Corn that I got from you last Spring. That corn developed better and stood the dry weather without turning a leaf, a thing no other corn did here last year in fields around it. I would recommend it to anyone in this part of the country.

Yours truly,

(Signed) F. J. Dishner.

Our Seed Corn is famous all over the Northwest. For special prices see colored sheet 


\section{Disco Pedigreed Seed Corn}

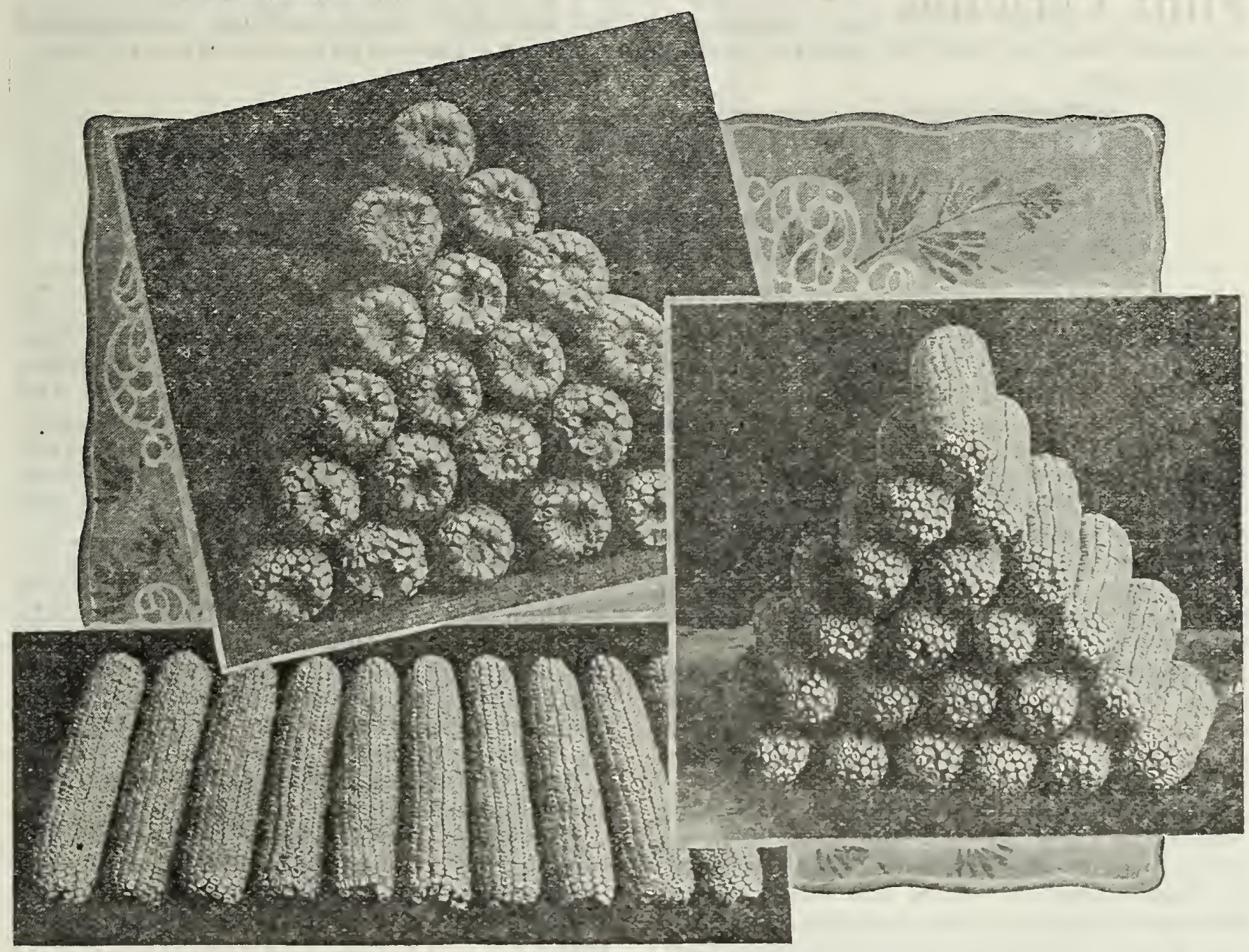

Disco 90-Day White Dent

DISC0 90-Day White-Rapidly becoming the most popular white variety on the market, is unusually early ripening, and a heavy yielder. Admirably adapted to northern sections of the country. The stalks grow to an average height of about eight feet and ears shoot out about three and one-half feet from the ground. We believe this to be the very best white dent on the market and aside from its value for production of corn it is especially valuable for silage purposes.

Silver King-A very early white dent corn maturing a few days later than our 90-Day White, but produces a larger ear and deeper kernel. Recommended for southern South Dakota, southern Minnesota, Michigan, Wisconsin and the Eastern States. Produces 12 rows of deep grained kernels. Ears well filled, medium size, about 8 or 9 inches long. Does well in either wet or dry weather.
Northwestern Red Dent-Has now been on the market for 25 years and is still gaining in popularity. For the Northwestern States and Canada, we believe it is unequalled. Is really a hybrid type, being a cross between an early yellow dent and a flint variety. Many instances are on record where this corn has matured in eighty days, but even where it is grown for the silo it will mature corn sufficient to greatly increase its value for silage purpose. Usually grows to a height of from six to seven feet. The ears are well formed, averaging eight inches in length with fourteen rows of kernels. Particularly well adapted for hogging-off and if Rape is sown between rows at the last cultivation it gives splendid returns.

For special prices see colored sheet 


\section{“Disco" Pedigreed Seed Corn}

Flint Varieties The Flint type of corn is very popular in the Northern States or where the crop is to be used for er or in fact anywhere where earliness is demanded hardy types.

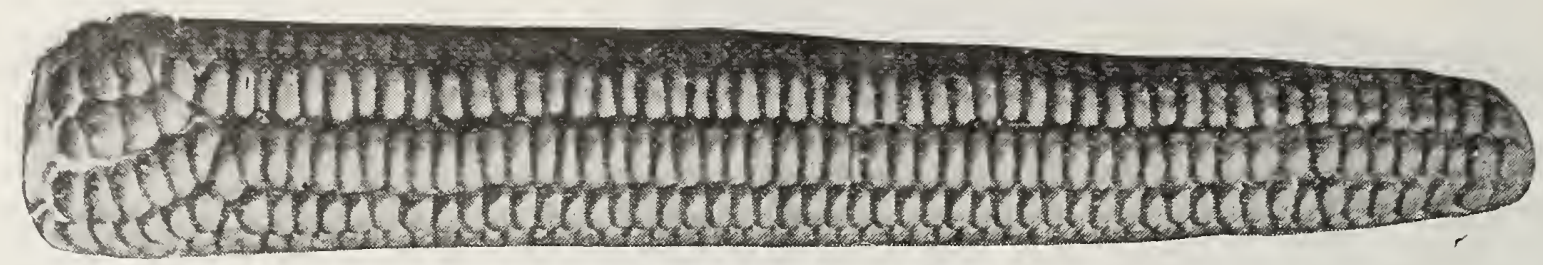

Longfellow Yellow Flint

Longfellow Yellow Flint (75-day Corn) - Particularly well adapted for Northern planting. Eight rowed ears, 10 to 15

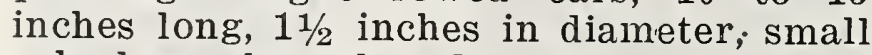
cob, large kernel and very broad. Very popular for the silo in Northern sections.

IISC0 White Flint-Pearly white, the ears have eight to ten rows and are eight to twelve inches long. Stalk grows four to six feet high. Ears borne from eight to twenty inches from the ground. A useful variety for hogging.

Gehu Flint-The earliest variety of Flint Corn. Ears small and are borne low down on the stalk. The color of the kernel is a light yellow. Will mature anywhere where corn can be ripened.

DISC0 Squaw or Rainbow Corn-An unusually early variety, the kernels being all colors of the rainbow. Very popular for late planting. Ears are much larger than Gehu, some over 12 inches long, and it is a corn of good quality and yields well.
King Philip Flint-Extra early red flint. We have had a stock of this excellent variety grown in South Dakota and the result is an unusually early and hardy type. We recommend this selection very highly, believing it will prove to be one of the best, produces an unusually large ear.

\section{Disco Fodder Corn}

DISCO Early Yellow Dent Fodder Corn -When sown thickly in drills at the rate of from one to one and one-half bushels per acre, this variety will give a surprisingly large amount of palatable feed, much relished by all stock. May be run through an ensilage cutter or be fed in the rack.

DISCO Medium Fodder Corn-A medium early maturing type.

Evergreen Sweet Fodder Corn-This variety grows a leafy stalk, six to seven feet in height, forms good-sized ears and yields a large amount of succulent fodder to the acre.

\section{Fodder and Sorghum Canes}

\section{Canes \\ Early Amber Fodder Cane- This is the earliest of all Fodder Canes and is best adapted to the Northwest, where it succeeds unusually well. Should be sown at the rate of from 40 to 60 pounds per acre.}

Dakota Amber Sorghum Cane-The earliest, richest and best Sorghum Cane for the Northwest, in fact we believe this is really the only variety that can be depended upon for the making of Sorghum or Syrup. Should be planted at the rate of from 4 to 8 pounds per acre, rows $3 \frac{1}{2}$ feet apart.

\section{Feterita}

This comparatively new grain, belonging to the Sorghum family, and introduced from Africa by the United States Department of Agriculture, has rapidly made a favorable impression wherever it has been sown. It is wonderfully drought resisting, early and beavy yielding and seems to be immune to the attacks of insect pests. If grown for the production of 'grain, should be sown in rows at the rate of 3 to 8 pounds per acre and cultivated, while if sown for fodder, should be broadcasted at the rate of $1 / 2$ bushel per acre.

\section{Kaffir Corn Makes excellent Fod-} cured. The stalks will grow four to five feet high, and are very leafy and relished by all kinds of stock. If grown for seed, will generally yield from 35 to 50 bushels per acre. If grown for grain, sow in rows three feet apart, three to five pounds of seed per acre, and for fodder, broadcast at the rate of $1 / 2$ bushel per acre.

Milo Maize to Kaffir Corn, but is $_{\text {bimilar in growth }}^{\text {Ver }}$ preferred by many growers, who claim that it produces more grain per acre and a better quality of forage. Should be sown in the same manner and at the same rate as Kaffir Corn.

For special prices see colored sheet 


\section{Disco M I L LETS}

\section{Millets}

today are occupying a much more important place in farm economy than ever. They constitute one of the best "catch crops" we have. Can be sown later than almost anything else and will give very fair returns under the most adverse conditions. We strongly recommend every farmer to include a quantity of Millet with his order, so as to have some of the seed on hand in case an opportunity offers where it can be used profitably.

Western Golden-True Southern grown. Grows an exceptionally sweet and palatable hay. Will thrive on almost any soil; attains a height of from four to five feet and is unusually drought resistant, producing a fair crop on even poor soils.

Dakota Kursk Millet-This variety is a native of Russia and has been grown here for over twenty years. Experiments conducted at the Experimental Stations in South Dakota have demonstrated beyond dispute the value of this variety. As a hay and seed producer it is without equal and in dry seasons it seems it will outyield any other variety. We confidently recommend our Dakota Kursk, believing that it will be entirely satisfactory.

Siberian Millet-A very fine variety of millet, also hailing from Russia. Unusually early, extremely hardy and withstands drought. The plant shows a remarkable stooling habit, as many as thirty to forty stalks being frequently grown from one seed.

Golden or Liberty Millet-(True Southern Grown Seed.) Under favorable conditions the Golden Millet will undoubtedly produce the heaviest yield of hay per acre. It grows very densely and is an excellent cleaning crop.

Hog Proso or Broom Corn Millet-Can be used for hay or as a cleaning crop just the same as other millets. It, however, yields an unusually heavy crop of seed-from sixty to seventy bushels to the acre, and experiments at our Experimental Stations have shown that it is an excellent substitute for Wheat. The seed will mature and be ready for cutting as a rule two months after date of seeding.

Early Fortune Millet-Of the same type as Hog or Broom Corn, with the exception that the color of the seed is red, whereas the $\mathrm{Hog}$ is white. It is a good yielder, the seed being very valuable for either poultry or hog feed and it also yields a heavy weight of fodder.

Japanese Millet-This is entirely distinct from other varieties of millet, both in habit of growth arid character of seed. On account of its great value, it has sometimes been called "Billion Dollar Grass." Will grow from six to nine feet high, stands up remarkably well and yields enormous crops.

\section{Discos Selected Grass Seeds}

\section{Timothy}

(Phleum pratense)-One of the most useful and valuable grasses; of wonderful seeds being and unually productive; the seeds being very small and produced in great abundance, makes it the most economical of grasses; extremely hardy; seldom winter-kills and stands heat and cold equally well. Sow 10 to 12 pounds to the acre.

Awnless Brome Grass (Bromus inernus) - A native of Russia, well adapted to a cold climate. One of the deepest rooting grasses in cultivation. Suited to dry soils. Makes the best of pasture, being green the first thing in the spring and late in the fall. Sow from 20 to 25 pounds per acre.

Western Ryo Grass (Agropyrum tenerum) Sometlues known as siencer Wheal cirass. Adapts itself to varied conditions and will thrive almost anywhere; grows successfully even in alkali soil; yields an abundance of nutritious hay. Sown on land that has become worn out and depleted of fibre, after two or three years, whether sown for hay or pasture, when broken up will be almost like new land. Sow 15 pounds to the acre.

Meadow Fescue or English Blue Grass (Festuca pratensis)-A very useful grass for permanent pasture; makes excellent hay. Sow 15 pounds to the acre.

Red Top, Solid Seed (Agrostis vulgaris)-Also known as Herd's Grass, grows most luxuriantly on moist, rich soils; very robust; produces strong, thick roots and makes a firm sod very desirable for pasture purposes. Will succeed well on alkali land where other grasses fail. Sow 10 to 12 pounds of solid seed per acre.

Kentucky Blue Grass (I'on pratensis)-Also known as "June Grass." Produces an excellent pasture of a beautiful verdant green and is particularly adapted for seeding on a pasture field surrounding the home where a good sod of pleasing appearance is desirable. Sow from 30 to 40 pounds per acre.

Canadian Blue Grass (Poa compressa)-Very similar to the IKentucky; grows coarser, and the stems, as its botanical name indicates, are flattened. It will grow on poor soils where Kentucky would not thrive.

Perennial Rye Grass (Lolium perenne)-An excellent grass for permanent or temporary pas ture. The hay is relished by all linds of stock and will also stand close pasturing. Sow 15 pounds per acre.

Crested Dogstail (Cynosurus cristatus) - A very hardy, compact growing grass, which forms a lasting turf. The roots penetrate deeply and the plant withstands dry weather unusually well. Sow 30 pounds per acre.

Orchard Grass or Cocksfoot (Dactylis glomerata) - A very useful grass either sown alone or combined with other grasses for permanent pasture. One of the earliest grasses in the spring; is unusually productive. 


\section{"Disco" Forage and Soiling Crops}

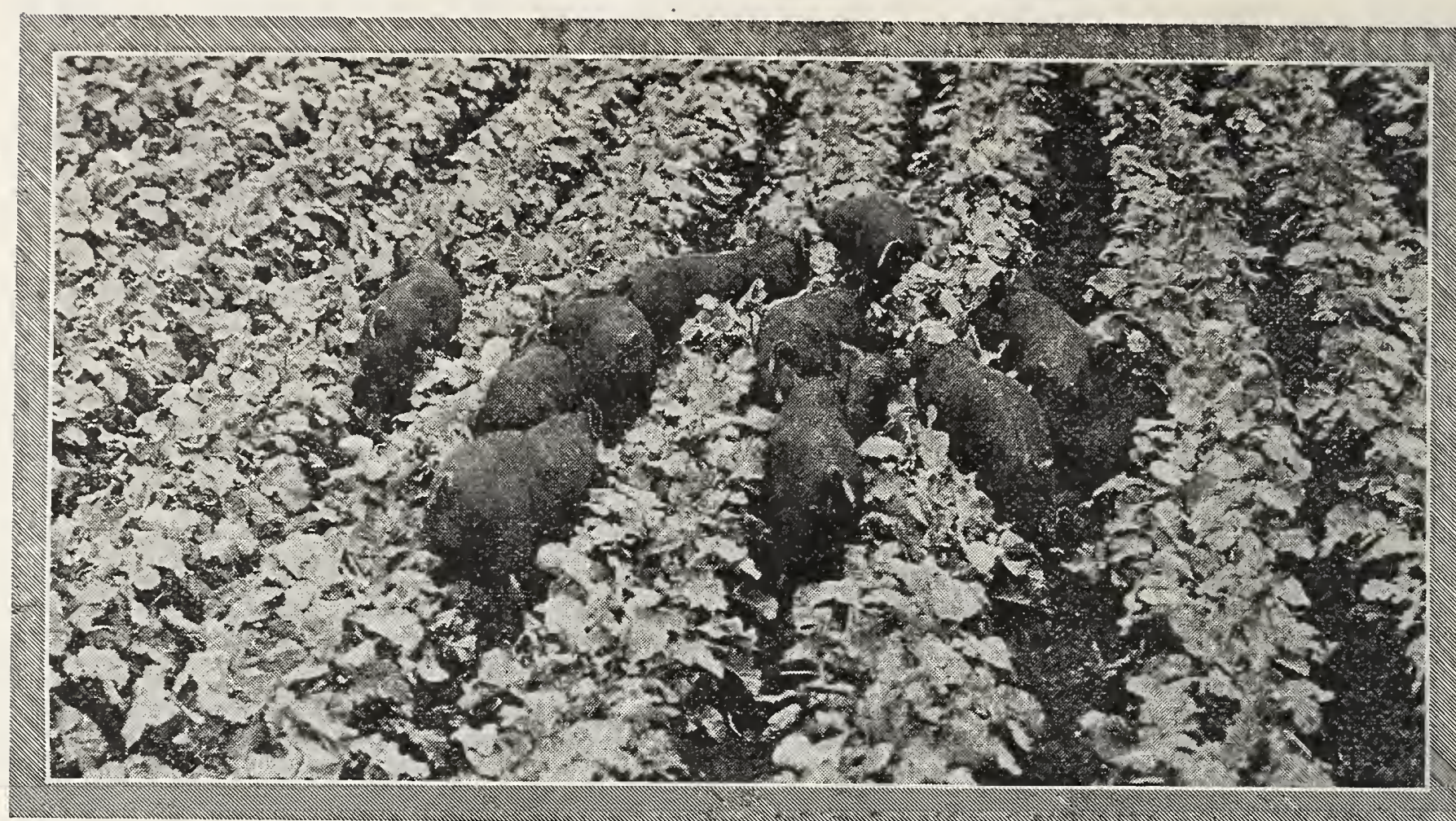

Rape $_{\dot{j}}$ Dwarf Essex

Rape can be put to quite a number of uses. It may be sown alone as a spring crop to provide early pasture. It may be sown with spring grain to provide fall pasture after the grain is cut. In this latter case it is better sown after the grain is up and the ground dragged immediately after sowing to cover the seed. As it is a common practice to drag or weed our grain crops after they are up, the sowing of rape at this time can be easily done. Rape may also be sown just before the last cultivation of corn to provide fall feed and increase the yield of feed per acre, or rape may be sown with fall rye to provide fall pasture.

The uses of rape are hardly limited to those mentioned above, as it may be sown at almost any time of the year and will provide quickly a large amount of forage. The farmers of the Northwest have not yet come to realize the possibilities of rape. There are thousands of acres of land sown to small grains that could be made to yield an abundant fall pasture by the sowing of two pounds of rape seeds to every acre of ground. The cost of the seed is so little and so small an amount is required that there is really no expense connected with it compared to the value: of feed that is secured. The amownt of seed that is sown per acre varies from two to six pounds, depending upon the way it is handled. When sown alone, from five to six pounds are recommended. When sown with small grain, two, to three pounds.

It pays to have rape seed on hand on the farm. There are often times when its could be profitably used if you just had it handy without having to send for it.

\section{Sunflower Russian Gian $\mathbf{t}$ - The} been value of this plant has been demonstrated with.unusual emphasis during the past few years and it is now being used extensively as far north as Edmonton in the Canadian West. Used in the silo either alone or in conjunction with corn, it provides excellent feed and gives a heavier weight per acre in the North than can usually be obtained by the sowing of corn. Aside from its value in the silo, for poultry feeding it is second to none, and the dry stalks make excellent kindling.
Buckwheat An excellent catedcrop, develops very rapidly. Useful either for hay or if allowed to mature gives an excellent grain crop which is much in demand for both poultry feeding and household use.

Japanese-The best variety for the Northwest. Produces its seed earlier, resists drought and is vory dependable.

Silverhull-While not quite so early as Japanese, is preferred by millers, as it makes a whiter, better and more nutritious flour. A nice variety to sow where bees are kept.

For prices see special price sheet 


\section{LOisco Forage and Soiling Crops}

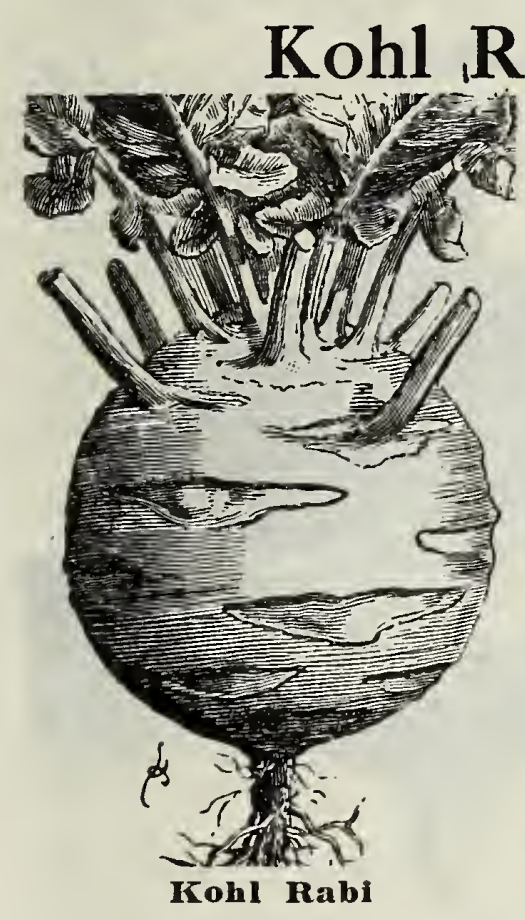

Mammoth or

Large Green

The value of $t h$ is excellent root is not sufficiently appreciated. For early fall use it possesses features wh i c h distinguish it from other roots and fod d e $r$ plants which justify its being included. P k t., 10c; oz., 25c; $1 / 4$ 1b., 75c; 1b., \$2.50; 5 lbs., $\$ 11.50$, postpaid.

\section{Kale, Thousand Headed}

Belongs to the cabbage fam ily and is sometimes known as Thousand Headed Cabbage. Will grow 3 or 4 feet high, a $n d$ produces an abundance of succulent leaves a 11 round the $\mathrm{st}$ e $\mathrm{m}$. These leaves a $\mathrm{r}$ e greedily eaten by stock; sheep being especially fond of them. S p l e $n$ d id for poultry. Sow in drills 30 inches

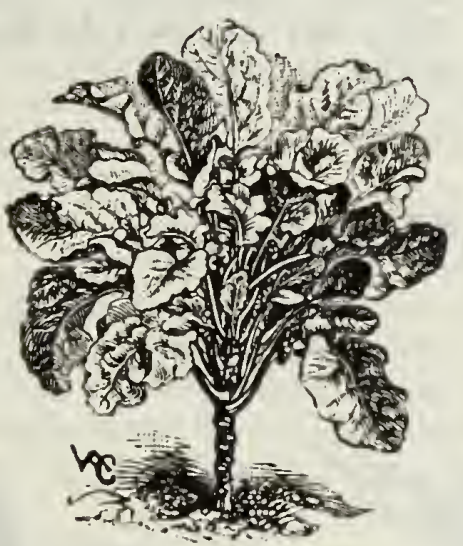

Kale, Thousand Head apart, and thin out to 24 inches between each plant. In well prepared land, with frequent cultivation, will produce 15 tons of green feed per acre. Provides A1 pasture for all kinds of stock. Ox., 10c; 1/4 lb., 30e; lb., B0c, 5 lbs., \$3.75, postpaid. Sudan Grass $\begin{gathered}\text { A great drought re- } \\ \text { sistant } h \text { a } \text { c }_{\text {r o p }} \text {. }\end{gathered}$ Th is comparatively new grass has very rapidly made a place for itself in agricultural economy all over the United States and Canada. Being sus ceptible to frost it should not be sown until late in the season, but under favorable circumstances will mature in a marvelously short period of time; the first crop being ready to cut less than fifty days after seeding, and after cutting, it renews its growth promptly, and generally speaking, in from 30 to 40 days another cutting can be made. Will grow in almost any kind of soil; is unusually drought resistant. Provides excellent hay which is easily cured. The seed we offer is free from impurities of any kind and is of high vitality.

\section{Kale Giant Marrow Stem}

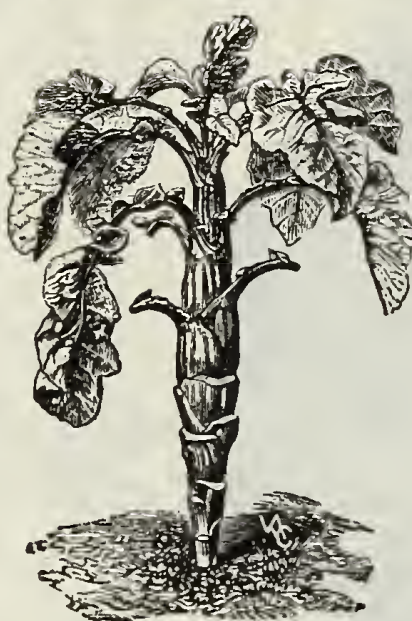

Sometimes referred to as Duplex RapeKale on account of the fact that not only are the leaves useful for stock, but the thickened stem, which is full of marrow and is sof e r th a $n$ turnip, is of high feeding value and greatly relished by stock. For summer and early fall feeding is invaluable, as not only does it produce a great weight of leaves, but the stems are of inc a l c u l a b l e value. Kale Marrow stem Grows between 4 and 10c; oz., 20c; 1/4 lb., 65e; lb., \$2.50; 5 1bs., $\$ 12.00$, postpaid.

\section{Soy or Soja Beans}

The value of this crop for silage, hay, hogging off and as a soil builder is annually becoming $\mathrm{m}$ o $\mathrm{r}$ a p p e c i a t e d. Where planted with corn for silage the total yield $\mathrm{per}$ a c re is increased and $t h e$ feeding value of the silage $v$ e $r y$ $\mathrm{mu} \mathrm{ch}$ improved. We strongly recommend a trial of this excelle $\mathrm{nt}$ fodder crop.

Early $\mathbf{B} \mathbf{l}$ a $\mathbf{c}$ Undoubtedly the best early variety, and a d $\mathrm{m}$ irably adapted for the

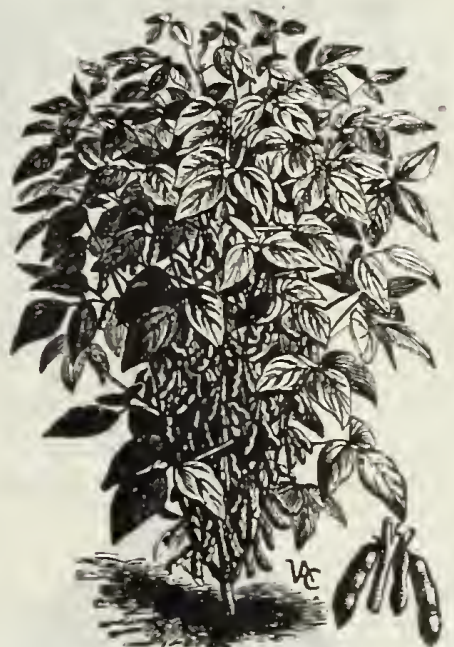

Soy Bean
Northwest. Grows from 18 to 20 inches high and matures in from 65 to 75 days.

Early Brown-Taller than the Early Black and is a trifle later. Well adapted for silo and hay. Grows from 24 to 36 inches high and is very leafy.

Hield Peas one of the best annual legume crops for the
Northwest, as the cool temperature at nights just seems to suit them and they make their best growth under such conditions. If sown with oats they make excellent feed and are more easily harvested and if necessary can be separated in cleaning.

Canadian Field-Grow to a height of four feet and will yield from 30 to 40 bushels per acre. Navy Beans grow i fe Dakota and a sure cropper. Well adapted to the Northwest. 


\section{"Disco" Pedigreed Field Roots}

\section{Purple Top Swede or Ruta Baga}

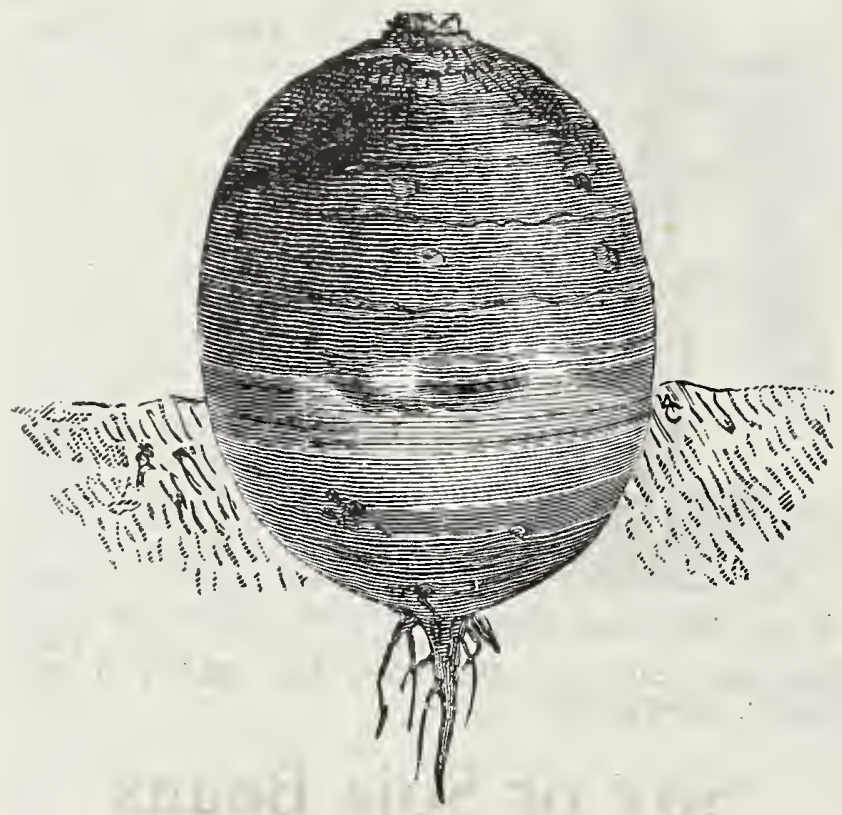

700 Monarch-An early, heavy cropping, oval-shaped Ruta Baga, of fine quality. Best for early use. Pkt. 5c; oz. 10c; 1/4 1b. 25c; 1b. 75c; 5 lbs. $\$ 3.50$, postpaid.

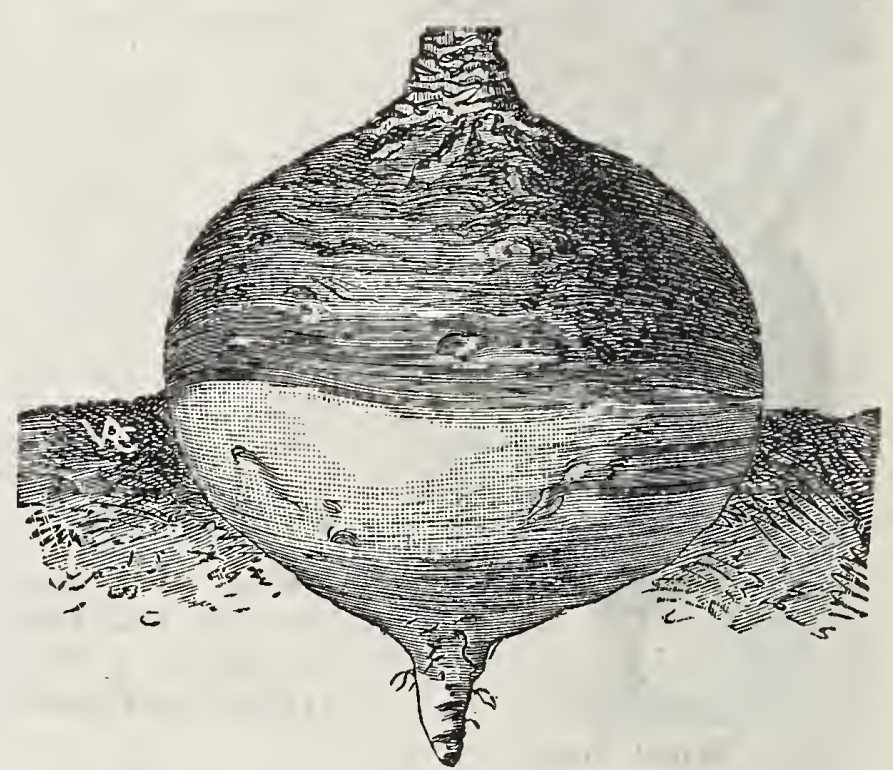

703 Bangholm - Hardy, round-shaped Swede, excellent cropper; good keeper. Pkt. 5c; 0z. 10c; 1/4 1b. 25c; 1b. 75c; 5 lbs. $\$ 3.50$, postpaid.

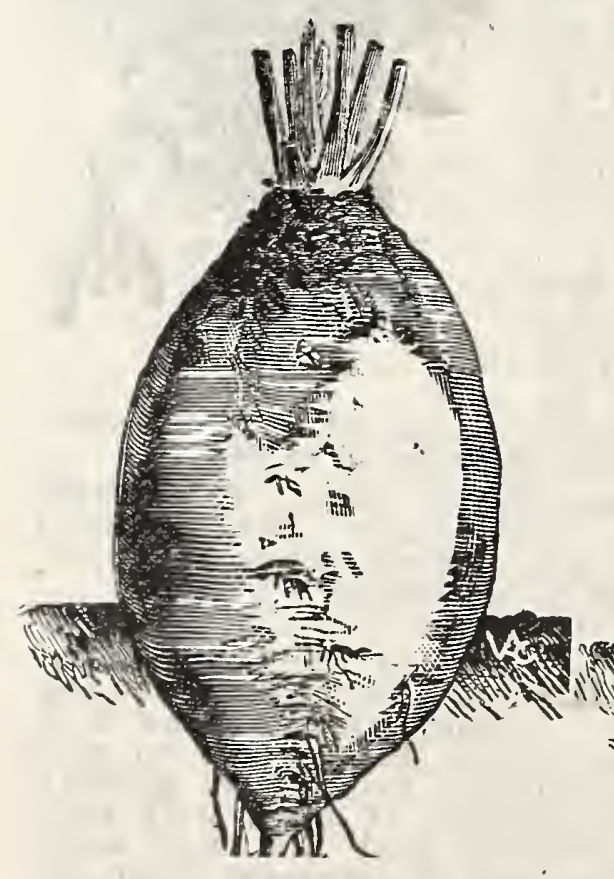

730 Giant Yellow, Intermediate or Gatepost - Grows to a great size, high out of the ground, good quality and heavy cropper. Oz. 10c; $1 / 4$ lb. 20c; lb. 50c; 5 lbs. $\$ 2.00$, postpaid.

\section{Mangel Wurzel}

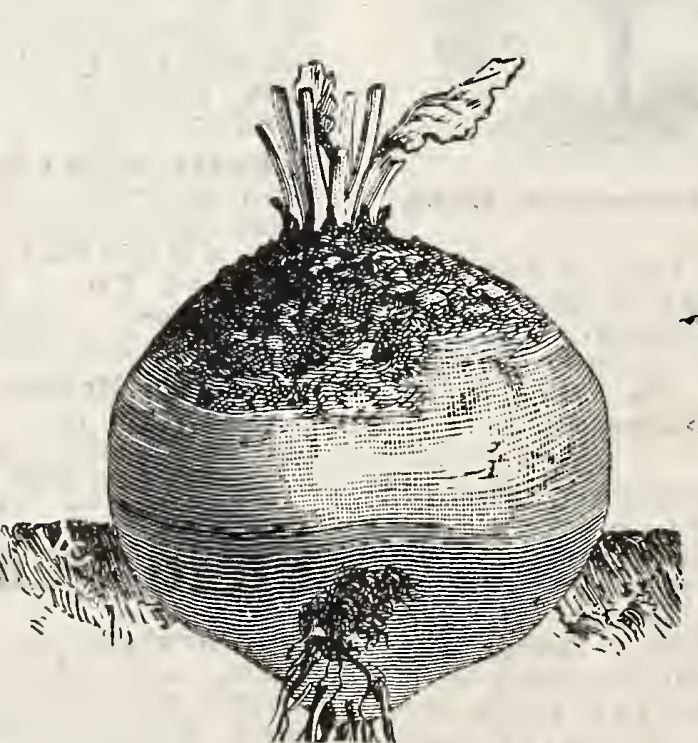

731 Prizewinner Yellow Globe-A longish globeshaped variety, very heavy cropper. Oz. 10c; 14 lb. 20c; 1b. $50 \mathrm{c}$; 5 lbs. $\$ 2.00$, postpaid.

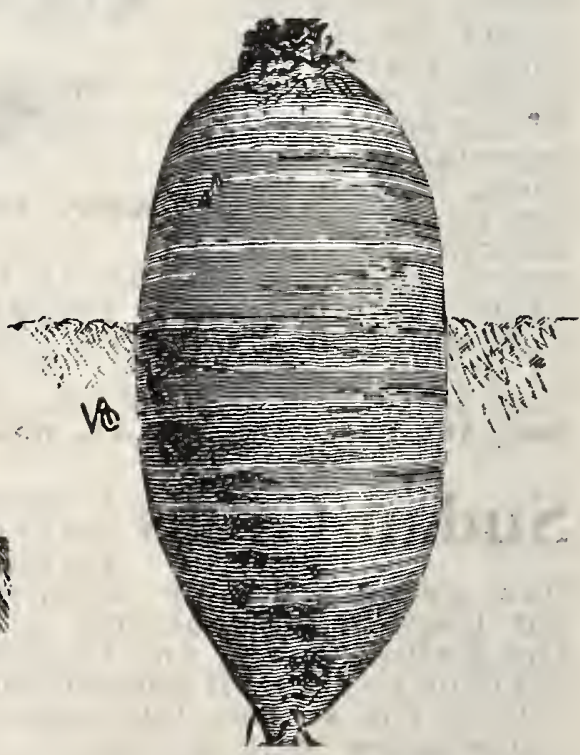

733 Selected Golden Tankard - Neat in appearance, with small tap root; a beautitul reddish golden skin, and sound, rich, firm yellow flesh. 0z. 10c; 1/4 lb. 20c; lb. 50c; 5 lbs. $\$ 2.00$, postpaid.

Your stock will thrive better if fed a root diet occasionally. 


\section{“Disco" Pedigreed Field Roots}

\section{Sugar Beet or Half Sugar}

Mangels 740 Giant Green Top White Beet or Half Sugar Mangel; bred to produce the highest percentage of feed value; a heavy cropper; much relished by stock; keeps well; easily harvested; skin a whitish color, shading to green at the top; flesh white, fine grained, solid, tender and sweet. 0z., 10c; 1/4 Ib., 20c; lb., 60c; 5 lbs., $\$ 2.50$, postpaid.

741 Giant Green Top Rose-Grows to an unusually large size; of exceptionally high feeding value; color bright pink shading to a lighter color at the bottom; flesh white, crisp and sweet. While the Sugar Beet does not produce as heavy a crop as Mangel, it is preferred by some, particularly for dairy stock. 0z., 10c; 1/4 lb., 20c; lb., 60c; 5 lbs., $\$ 2.50$, postpaid.

\section{Sugar Beet ${ }^{\mathbf{7 4 2}}$ Klein Wanzleben-} from the others offered; is not suitable for stock feeding, but the roots are used for the manufacture of sugar. In view of the high price of this commodity, which so frequently exists, we recommend every farmer to grow a few so as to produce enough sugar for home use. 0z., 10c; $1 / 4 \mathrm{lb}, 20 \mathrm{c} ; 1 \mathrm{~b} ., 60 \mathrm{c}$; 5 lbs., \$2.50, postpaid.

\section{Mangel Wurzel}

732 Selected Mammoth or Giant Long Red-

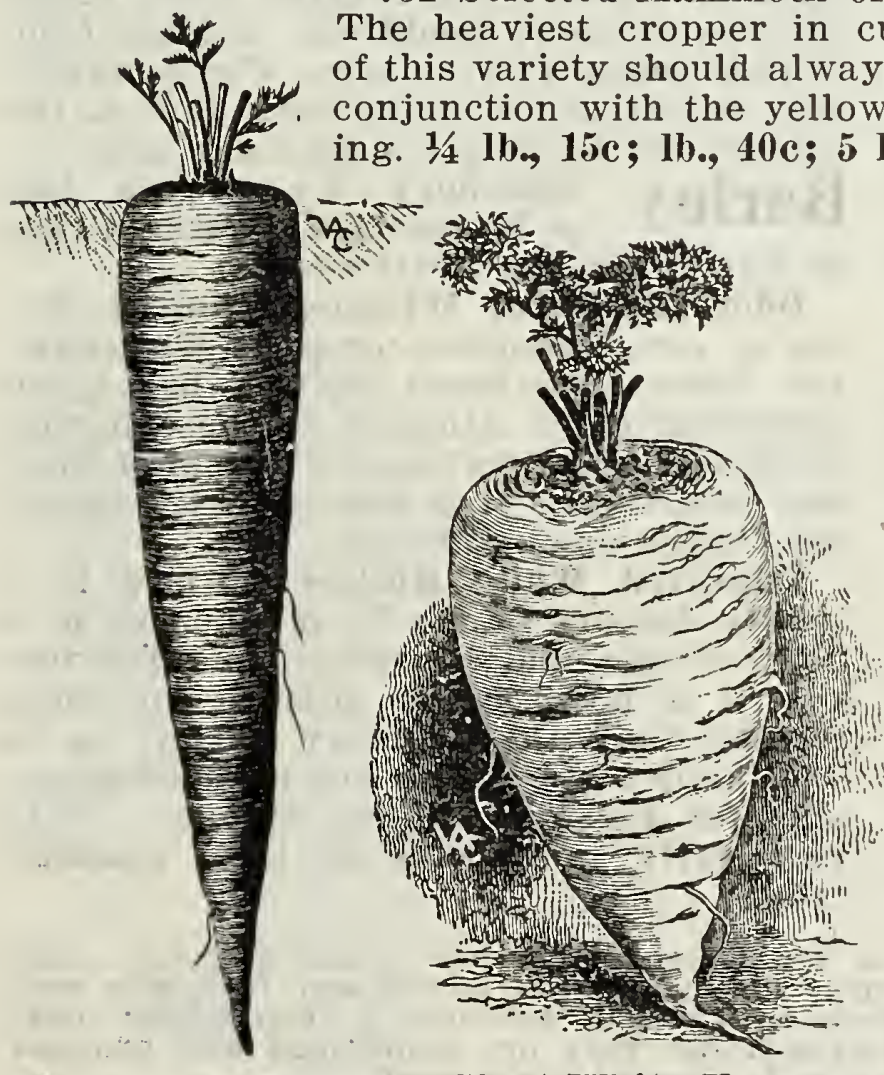

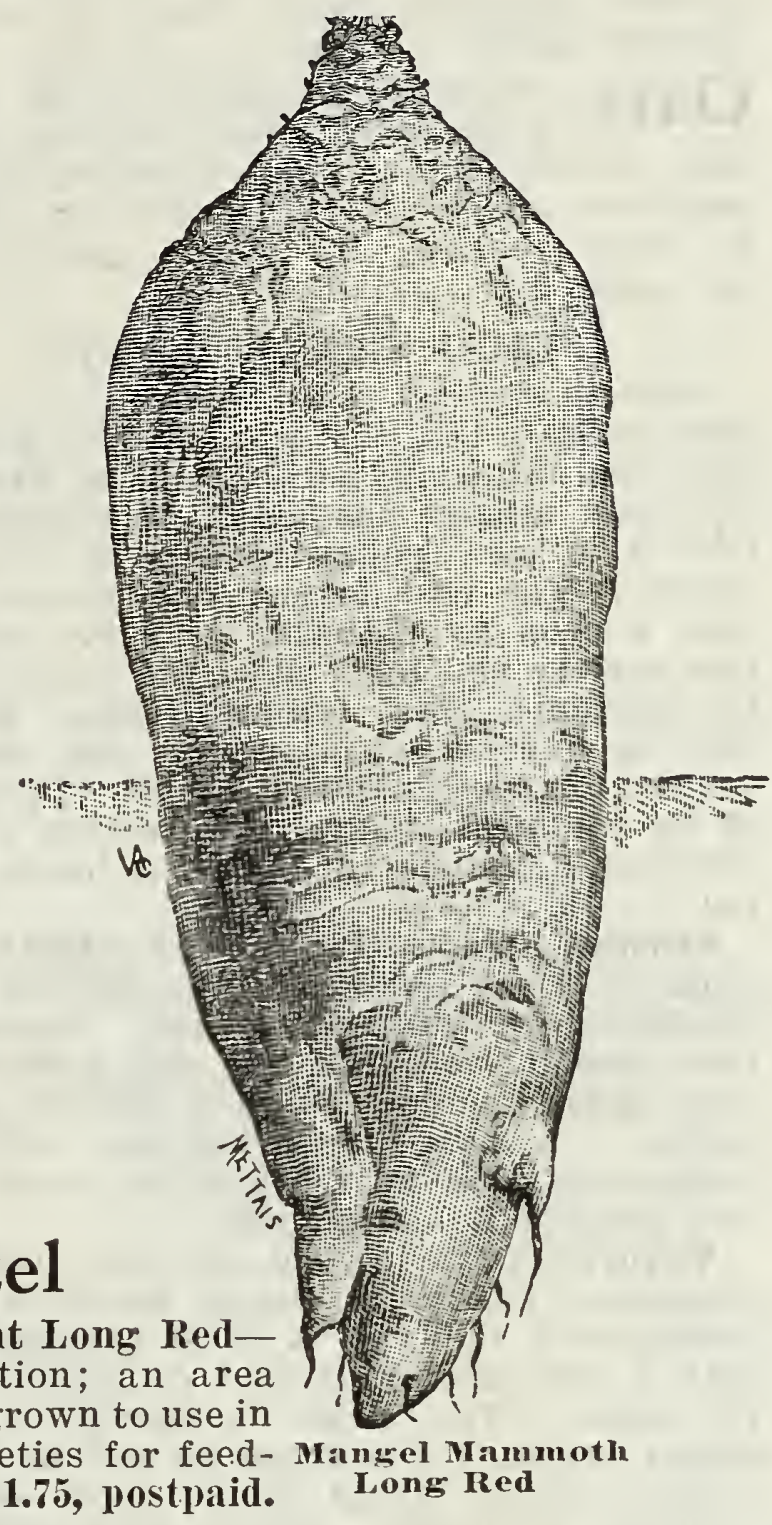

Field Carrots 750 Giant White Vosges - Very popular all over the world where Field Carrots are grown. An unusually heavy cropper; excellent feeding qualities. Pkt., 5c; 07., 10c; 14 lb., 20c; lb., 75c; 5 lbs., $\$ 3.50$, postpaid.

751 Long Red Surrey-Many prefer to grow an orange carrot on account of its better eating qualities. While it is admitted that white carrots are the heaviest yielding it is recognized that for eating purposes the orange carrots are in favor. Long Red Surrey is a heavy yielder, fine length, thick crown, very little core, smooth, sweet, clean, tender, crisp and mellow. Pkt., 5c; oz. 10c; 1/4 lb., 30c; lb., 90c; 5 lbs., $\$ 4.00$, postpaid.

Long Red Snrrey Giant White Vosges

Study this page carefully and try out an acre or two of roots. 


\section{Oisco Selected Pedigreed Seed Grains}

We exercise the same care in the selection of our Seed Grains as we do Alfalfas, Clovers and other seeds. They are sold on our Money Back Guarantee. We are not satisfied unless you are.

Oats We pride ourselves on the high grade of oats that we have been able to send out to our customers in the past and are glad to say that this year we have possibly the finest quality we have ever had.

\section{Disco Sixty Day}

Reports coming to us from all over the state indicate that this was the most profitable and uniformly successful Oat grown. The past season has again demonstrated that it is poor policy to depend on one variety. The wise farmer will always insure a crop.by planting an early and a late variety and thus offset the possibility of complete crop failure. Disco Sixty Day is beyond question the best early variety for the Northwest States. In spite of its earliness, taking the average crop, covering a number of years, it heads the list.

Swedish Select-Has rapidly established itself in South Dakota, Minnesota and the Northwestern States generally. Wonderfully drought-resistant and will produce a crop usually under the most adverse conditions. A nice appearing oat with a moderately thin hull, while the straw is stiff and not liable to lodge.

Victory-A variety of Swedish origin, sometimes known as Seger, which is the Swedish for Victory. A short grained oat with a very thin hull, and comparatively few awns. The straw is peculiarly resilient, enabling it to stand up well against storms which would cause most other varieties to lodge. Stools well and is excellent for sheaf feeding.

F/aX N. D. R. Wilt-Resistant-Flax does well in the Northwest and is a paying crop, being especially valuable for seeding on new land as it does well as a first crop on new breaking. Flax is also valuable for late seeding as it can be sown when it would be too late to expect a crop even from oats or barley. The seed we offer is grown on new land and is of fine quality and free from weeds.

\section{Spring Wheat}

Marquis Where this variety succeeds rust, there is nothing better. It has, however, shown a very decided tendency to rust in many districts, and we do not recommend it for general use. The stock of seed we offer is very fine, of high purity and germination, free from bearded heads, or other variations from the true type.

Kubanka Durum or Macaroni-Within the past few years has very rapidly increased in favor owing to the fact that it is unusually rust and drought-resistant. Where Marquis and other varieties have been completely destroyed by rust or have failed to produce a crop owing to drought, wonderfully good returns were obtained from Kubanka. We strongly recommend a trial of this variety.

\section{Acme Durum This is a very} the Durum type, which has given excellent results in many parts of the Northwest States. We have an excellent stock of high grade seed, free from weeds and true to type.

\section{New Red}

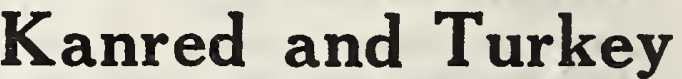
We have made arrangements to have a good supply of choice Certified Seed and will be glad to have inquiries in the Fall.

Speltz The value of this great crop is ized. It is somewhat similar to barley, although botanically it is more closely allied to wheat. One of the surest crops known. Gives good returns even under the most adverse conditions, yielding from 35 to 50 bushels to the acre. Can be profitably fed to all kinds of stock. Sow at the rate of two bushels ( 84 lbs.) per acre.

Barley Manshury-We believe this of Barley for the Northwest.

Oderbrucker, or Wisconsin No. 55-Being a very important crop in Wisconsin, the State Experiment Station has given somewhat close attention to the selection of Barley, and Oderbrucker is one of their best selections. It is said to be the heaviest yielder on the market.

Improved White Hulless - $\mathrm{T} h$ is is a totally distinct Barley in-as-much as it is both hulless and beardless, and for this reason is much better adapted for sheaf feeding than the ordinary barley, as is well known the beards are most disagreeable fed to stock in this manner. It is very early and makes an ideal cleaning crop.

SPRING RYE: Our sales last year were ten times more than usual and we could have sold much more only the supply gave out. Everyone that sowed our Rye was well pleased. As a spring grain crop it is hard to beat. Will produce a crop under most adverse conditions; not affected by rust, and even under very dry conditions will produca a crop. We have an excellent stock of plump well ripened clean seed.

In the Fall write us for samples and prices on Amber and Rosen Winter Rye. 


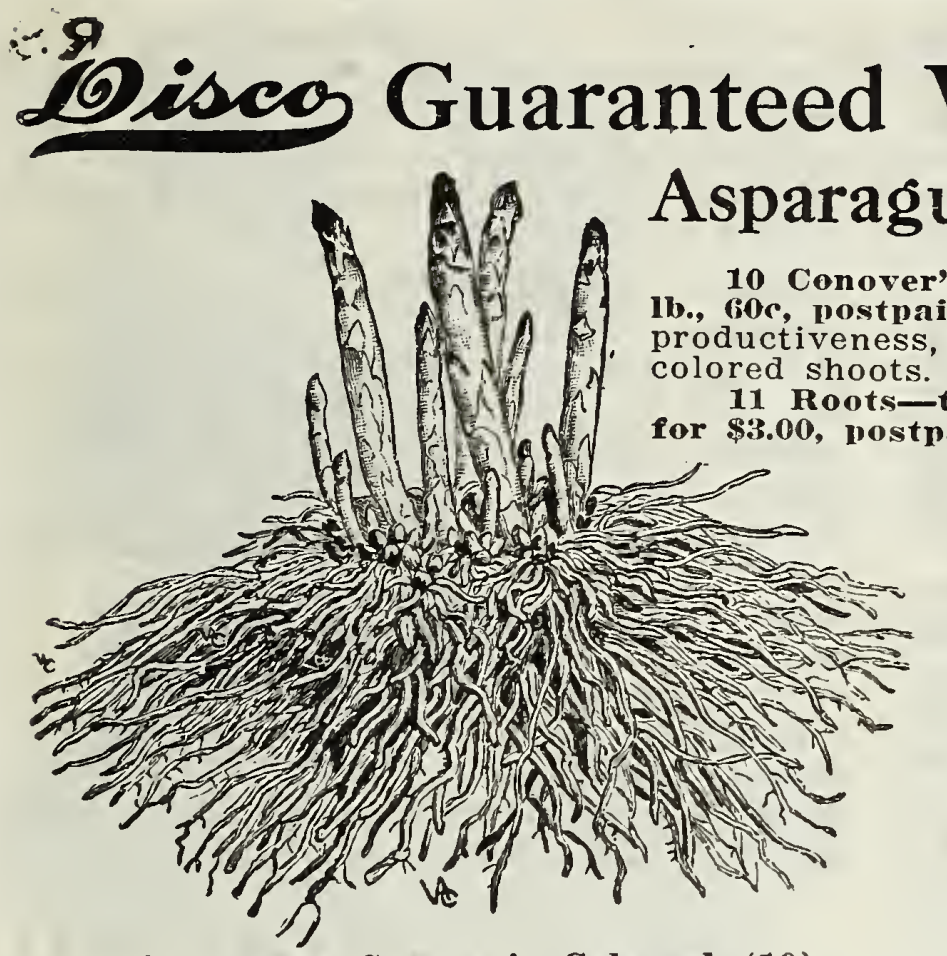

Asparagus Conover's Colossal (10)

\section{Vegetable Seeds}

One of the earliest and most delicious spring vegetables. Should be grown in every garden.

Colossal-Pkt., 5e; oz., 10c; 1/4 1b., 20c; Destinguished by its superior quality. See illustration.

vo-year old-Doz., 50c; 50 for $\$ 1.75 ; 100$

To insure hardiness, our BegnS Beans are grown as far ent with perfect maturity. We are not offering a lengthy list of varieties which usually only causes confusion. Our selection consists of what from long experience we believe to be the very best.

\section{Dwarf Bush Varieties}

20 Golden Waxpod, Imp.-Pkt., 10c; $1 / 2$ 1b., 20c; 1b., 30c; 5 lbs., \$1.25, postpaid. The most popular wax variety and one of the best. Very early and a heavy cropper, the pale yellow pods sometimes growing eight inches long. The flesh is brittle, stringless and of good quality. See illustration.

21 Disco Kidney Waxpod-Pkt., 10c; 1/2 1b., 25c; lb., 40c; 5 lbs., \$1.75, postpaid. Resembles the old favorite Wardwells but more robust and prolific. Pods are eight inches long, stringless, fibreless, very fleshy and brittle; attractive clear yellow color.

22 Pencil Pod Black Wax-Pkt., 10c; 1/2 1b., 20c; lb., 30c; 5 lbs., \$1.25, postpaid. The finest of the dwarf black seeded wax varieties. Exceptionally early and productive. Pods seven inches long, round, straight and crease-backed, perfectly stringless, fleshy and brittle.

23 Davis White Kidney Wax-Pkt., 10c; $1 / 2$ Ib., 20c; lb., 30c; 5 lbs., \$1.25, postpaid. Early, productive and attractive, pods large and flat, 7 inches long, very uniform and straight. color clear bright yellow. Seed white kidney shaped.

30 Black Valentine, Greenpod-Pkt., 10c; 1/2 1b., 20c; 1b., 30c; 5 1bs., \$1.25, postpaid. Beautiful large pods, slender, round and nearly straight, fine-grained, and a nice dark green color. More vigorous grower than Red Valentine.

31 Disco Stringless, Greenpod-Pkt., 10c; 1/2 1b., 20c; 1b., 30c; 5 1bs., \$1.25, postpaid. Very early, hardy, vigorous and productive. Large pods, stout, round, tender and brittle; dark green in color. Perfectly stringless. Finest quality.

32 Bountiful-Pkt., 10c; $1 / 2$ lb., 20e; lb., 30c; 5 lbs., \$1.25, postpaid. We consider this the best of the flat podded stringless varieties, pods 7 inches long, color light green. Very

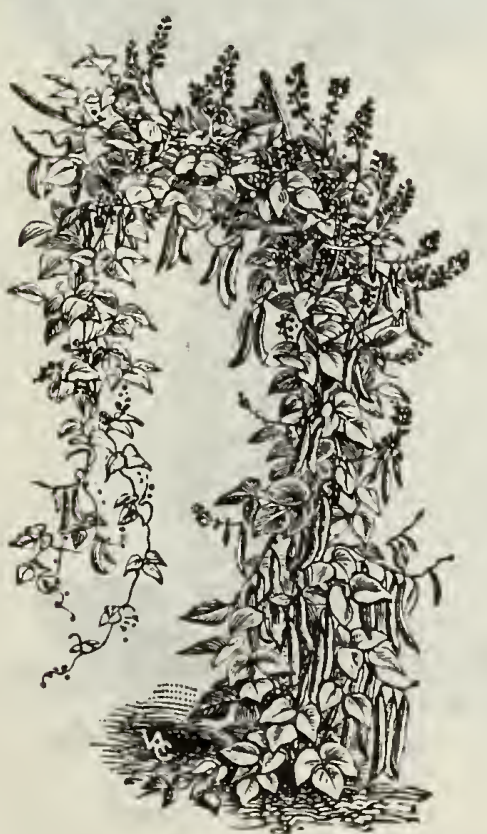
early, vigorous, hardy and productive.

\section{Pole or Climbing Varieties}

40 Emperor Scarlet Runner-Pkt. 10c; 1/2 1b., 25c; 1b., 45c; 5 llos, \$2.00, postpinid. The largest podded variety in cultivation, bearing a heavy crop of very fine handsome pods, borne in clusters, of excellent cooking quality. Useful also for trellis work or veranda covering, its bright scarlet flowers and verdant foliage being very effective. See illustration.

41 Horticultural Pole, or Cranberry (October Bean)-Pkt.. 10c; $1 / 2$ 1b., 25c; lb., 40c; 5 lbs., $\$ 1.75$, postpaid. The well known standard sort; very hardy and productive; medium early. The pods which grow from five to six inches long are straight, flat, stringless and of excellent quality. The color is a beautiful dark green, splashed with bright red.

42 Kentucky Wonder, or Old Homestead-Pkt., 10c; 1/2 1b., 20c; lb., 35c: 5 lbs., $\$ 1.50$, postuaid. This is probably the most popular green-podded, climbing, or corn-hill bean grown. Is very early and productive, pods will grow to eight and nine inches long; are very slender, curved, and of tender quality.

43-Kentucky Wonder Wax-Pkt., 10c; 1/2 1b., 25c; 1b., 40c; 5 Ibs. \$1.75, postmaid. One of the earliest of the pole wax varieties. Pods nine inches long, fleshy and brittle, color light yellow.

Emperor Senrlet Runner

Simple and easily followed Cultural Instructions supplied free 


\section{Lima Beans 50 Dwari Sieva Lima} 25c: lb., 40c; 5 lbs., \$1.75, postpaid. A vigorous, hardy, very early Bush Lima, much in favor for canning. Pods are three inches long-containing three to four small flat white beans of good quality.

51 Fordhook Bush Lima-Pkt., 10c; 1/2 lb., 25c; lb., 40c; 5 lbs., \$1.75, postpaid. One of the most popular, both for home use and with market gardeners. Pods usually grow about five inches long, contain four to five large, oval-shaped, very thick white beans of the Potato Lima type.

52 New Wonder Bush Lima-Pkt., 10c; 1. Ib., 25c; lb., 35c; 5 lbs., \$1.50, postpaid. A very fine mid-season variety and a heavy producer, unusually dwarf. Can be planted closely. Beans are very broad and are as large as many of the Pole varieties. The advantage of this variety being that it can be grown even in the smallest gardens where the Pole varieties would take up too much space.

\section{Beet (Table) No garden should} erous sowing of this excellent blood en.riching vegetable, which is so easily grown.

70 Crosby's Egyptian-Pkt., 5c; oz., 10c; $1 / 4$ lb., 30c; lb., F5c, postpaid. Our strain of this popular beet is an exceptionally good one, if thinned out at the proper time,

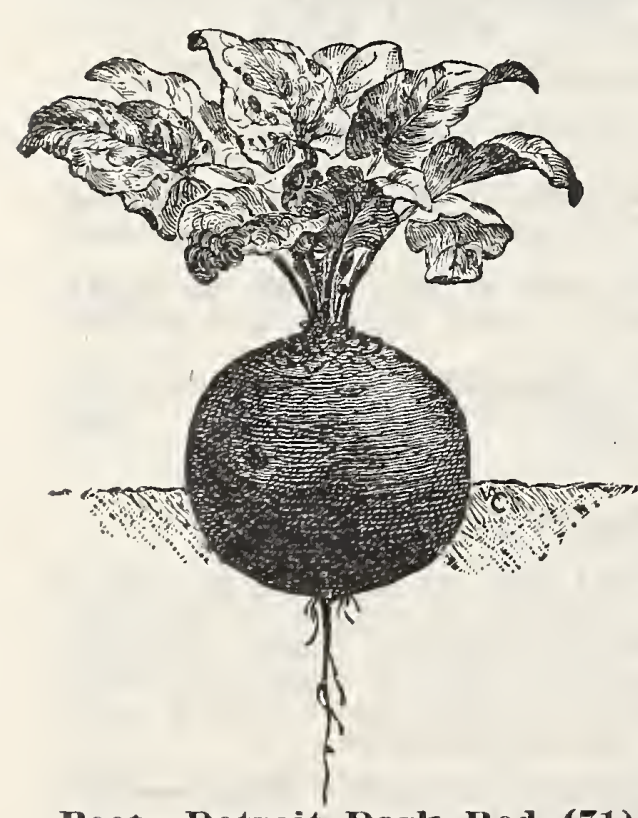
will produce nice $\mathrm{s}$ i z e d $\mathrm{s} \mathrm{h}$ a p e l y r o ots, very rapidly.

A flattened globe shape; $\mathrm{sk}$ in $\mathrm{ver}$ y d a r k red; flesh a trifle lighter a $\mathrm{d}$ li g h t l y zoned; p r od u c e s very small tops.

71 Detroit Dark Red Pkt., 5c; oz., $10 \mathrm{c} ; 1 / 4 \mathrm{lb}$. Beet-Detroit Dark Red (71) 30c; 1b., 75c, l) o s t p a id. One of the very best sorts for home or market garden and for canning or pickling. Roots uniformly smooth, medium size and beautifully globe shaped; skin blood red, flesh dark red, zoned with a lighter shade; quality tender and sweet.

72 Extra Early Flat Egyptian-Plt., 5c; oz., 10c; 1/4 lb., 30c; lb., 75c, postpaid. Without doubt one of the earliest varieties

in cultivation. Tops are unusually small; roots being distinctly flat, rather than globe shaped; color a dark red; flesh a dark purplish-red, zoned to a lighter shade. A splendid variety for first crop for either market or home use.

80 Swiss Chard, Lucullus - Pkt. 5c; OZo, 10c; 1/4 $1 \mathrm{~b} ., 25 \mathrm{c} ; 1 \mathrm{~b} ., 75 \mathrm{c}$, postpaid. The cut and come again Spinach. If its merits, usefulness and easy cultivation, were even half appreciated, it would înd a place in

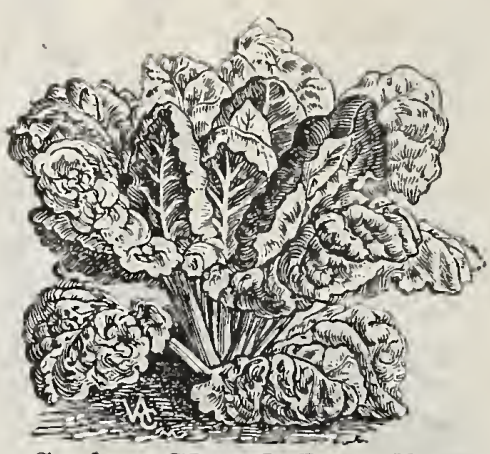

Swiss Chard Lueullus (80) every garden. Produces abundance of greens which can be used all summer.

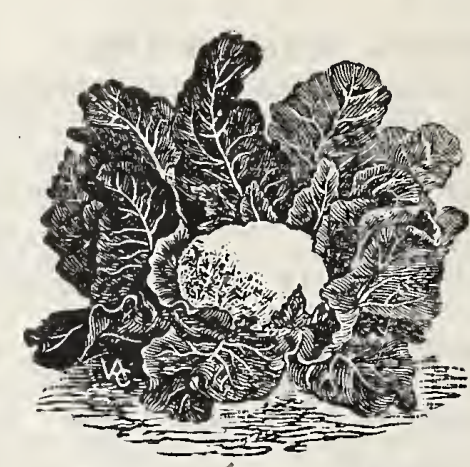

Broceoli Walcheren (90)
Broccoli

A vegetable very similar to Cauliflower, but hardier, and, owing to the peculiar growth of the inner leaves, will keep fit for use longer and can be grown later in the season.

90 Walcheren Pkt. 5c; oz., 20c; 14 lb., 75c, postpaid. The earliest variety, the link between Broccoli and Cauliflower and the best for use in the Northwestern States. For Borecole see under Kale.

\section{Brussels Sprouts}

\section{$\mathrm{M}$ i n i a t u re} Cabbages p r oduced on a plant stalk, used like cabbage. $\mathrm{Th}$ h delicate flavor is improved by a slight touch of frost.

100 Standard -Pkt., 5c; oz., $15 \mathrm{c} ; 1 / 4 \quad 16 ., 55 c$, pos t p a id. A magnificent variety with large solid s prouts produced $\mathrm{fr}$ o $\mathrm{m}$ top to bottom.

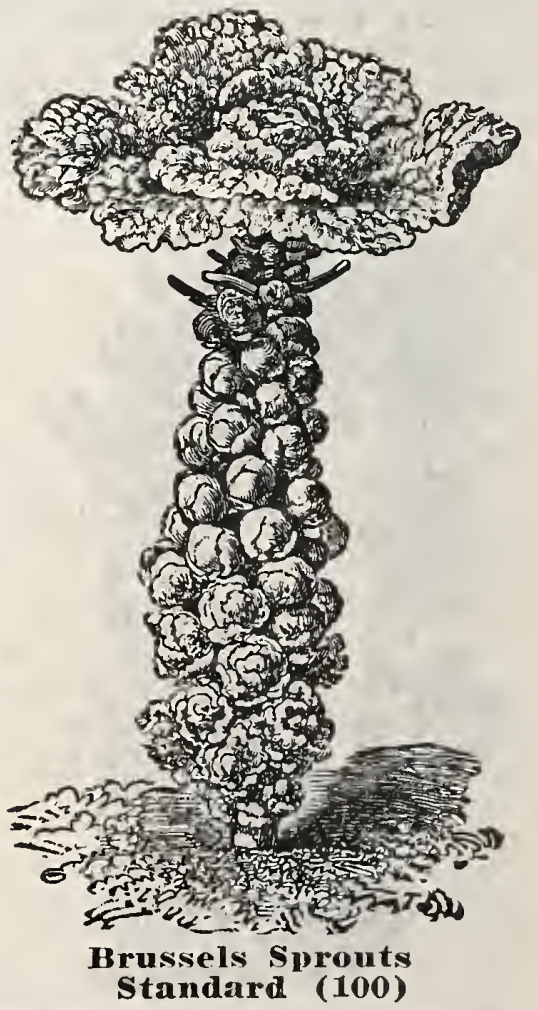

Disco Vegetable Seeds are the standard of excellence. 


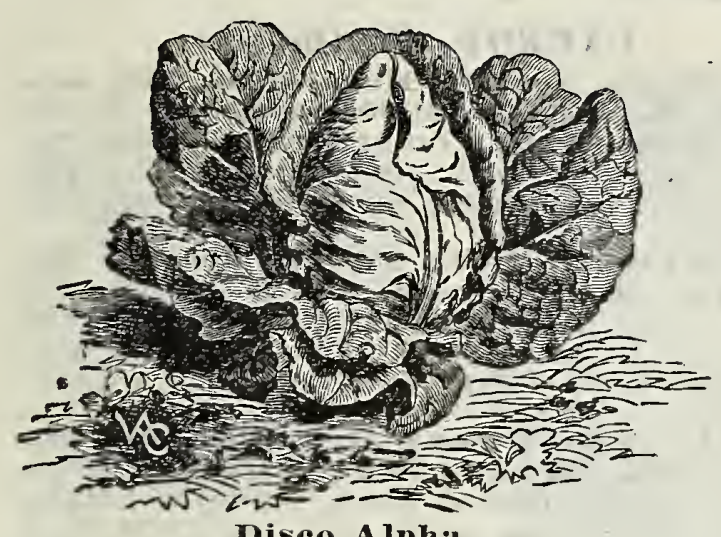

Disco Alpha
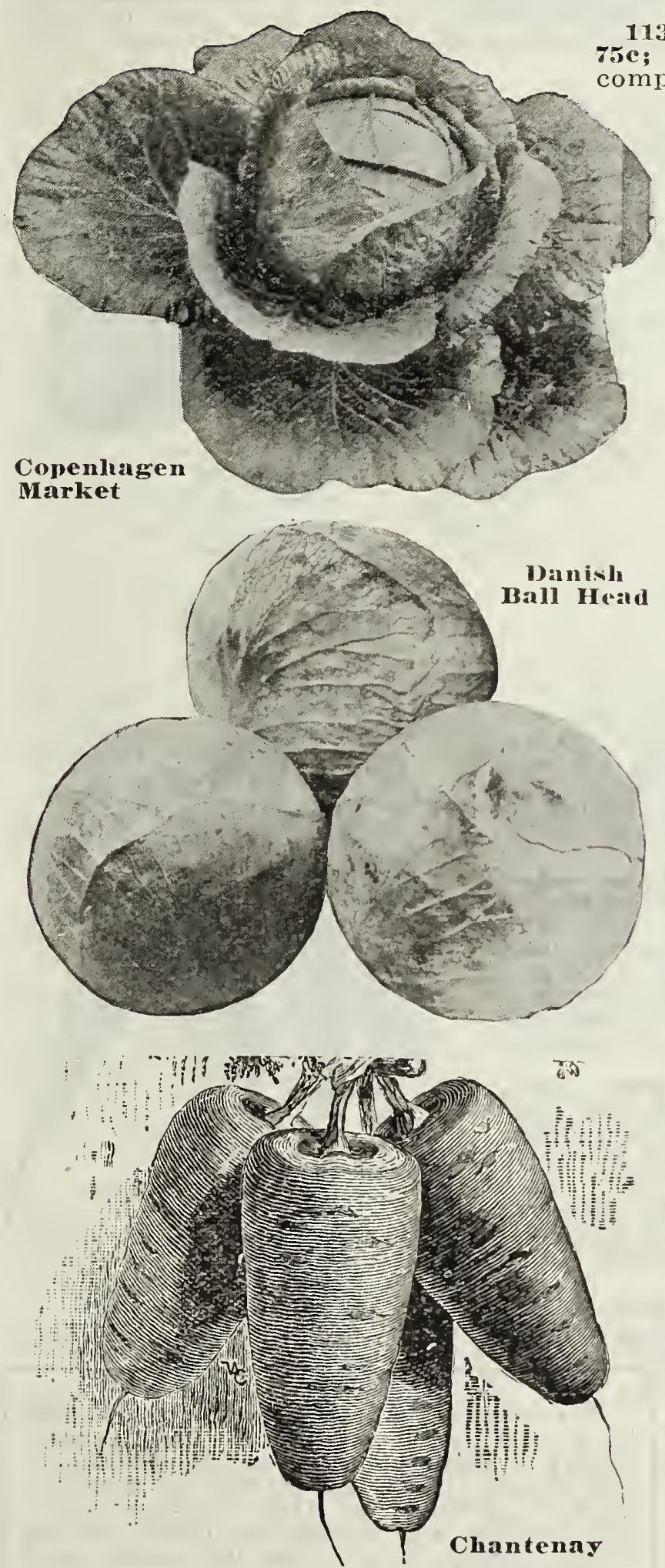

Cabbage The selection of varieties we supply all the year round.

110 Disco Alpha-Pkt., 5c; oz., 20c; 1/4 lb., 70c; 1b., \$2.00, postpaid. The earliest variety in cultivation. Should be sown for first crop.

111 Early Jersey Wakefield-Pkt., 5e; oz., 15c; $1 / 4$ Ib., 55e; 1b., \$2.00, postpaid. Early pale glaucous green, with blunt conical heads of good size. The most widely known and popular variety.

112 Early Winningstadt-Pkt., 5c; oz., 20c; 1/4 lb., 70e; 1b., \$2.00, postpaid. Early main crop, firm, compact, short conical head, rather leafy, leaves undulated at the edge. One of the best for either early or late use.

113 Copentiagen Market-Plkt., 5e; oz., 20c; 1/4 lb. 75e; 1b., \$2.25, postpaid. Short-stemmed, growth compact, outer leaves small, tightly folded over a solid flattish ball-shaped head with fine veins and small core, averaging about ten pounds in weight. Can be planted closely together ind will yield a greater crop per acre than any other cabbage. Our stock is true to type and matures with great uniformity.

114 Glory of Finkhuizen-Pkt., 5e; oz., 20c; $1 / 4$ lb., Foc; 1h., \$2.00, postuaid. Short-stemmed medium early, with large round very hardy head and few outer leaves, which perinits close planting. A good keeper and splendid for winter use. Should be grown as a succession crop to Cophenhagen Market.

11.5 Premium Flat Duteh-Pkt., 5e; oz., 15e; 1/4 lb., 55e; 1b., \$2.00, postpaid. Large heads flattened on the top, very full and firm, long stem. Will stand more frost than most varieties, and may be left later in the ground.

116 Danish Bull Head-Pkt., 5e; oz., 20e; 1/4 lb., 70c; lb., \$2.00, postpaid. A very distinct short-stemmed cabbage, with round, very hard and solid heads, a late variety, popularly grown for keeping through the winter.

117 Danisle Round Head-Pkt., 5c; oz., soc; 1/4 1b., 70c; 1h., \$2.00, vostpaid. Similar to Ball Head, slightly larger, longer stem and about two weeks earlier. Very hard and heavy.

120 IRed Dutch Dw:trf-Pkt., 5e: ox., 25c: 1/4 1b., 90e; lb., \$3.00, postpaid. The earliest of the Red varieties, and the best for pickling.

140 Savoy Dwarf Green Curled-Pkt., 5c; oz., "25e: $1 / 4$ 1b., 90c; 1b., \$3.00 postpaid. Sometimes described as the "Honey Comb Cabbage." Hearts quite green and very solid will stand twenty degrees of frost, and remains a long time on the ground fit for use.

150 Chinese (Pe Tsai)-Pkt., 5c; oz., 20c; 1/1 1b., 75e; 1h., \$2.75, postpaid. Celery cabbage, resembles Cos Lettuce, but has a decided cabbage flavor.

\section{Carrot you can make an enjoyable}

160 Chantenay-Pkt., 5c.; oz., 10c; 1/4 1b., 25e; 1b., 80e, bostpaid. Excellent medium carly half-long stump rooted variety, about six to eight inches long, very thick, smooth and of a deep orange-red color. This variety and Oxhealt are really the most popular sorts.

161 Danvers Half Long-Pkt., 5c; oz., 10c: 1/4 Ib., 25c; 1b., 80c, postpaid. Pale color, half-long semi-stump rooted. Short top. Very sweet and tender quality flesh.

Cabbage and Carrot should be in every garden 

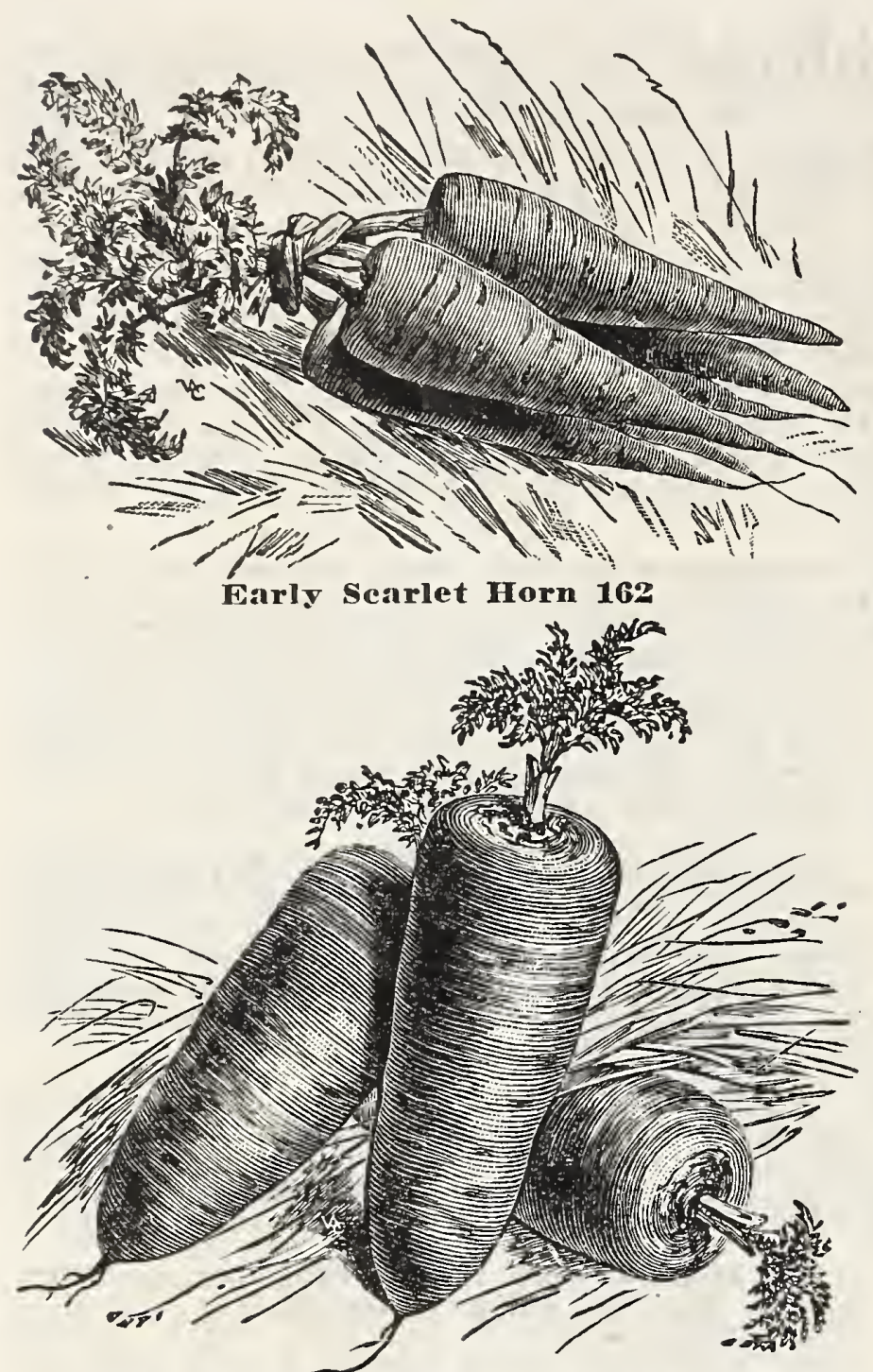

Danvers Half Long 161 (See page 19)

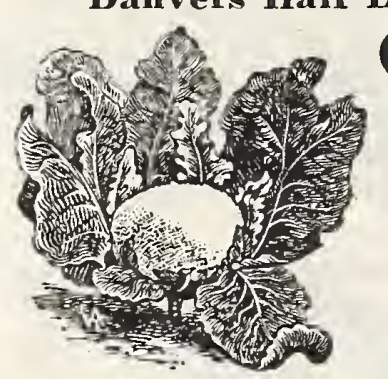

Canliftower

\section{Cauliflower} the three sorts we offer, according to our instructions, and we guarantee uccess.

170 All Seasons, Extra ImprovedPkt., 20c; 1/4 oz., 75c; oz., \$\$2.00; 1/4 lb., \$6.00, postyaid. We gave the name "All Seasons" to this variety as it very aptly describes its characteristic. By sowing at intervals, splendid heads of Cauliflower may be available throughout the whole season. The quality is excellent and we cannot too strongly recommend it.

171 Early Snowball, Extra Selected-Pkt., 10c; 1/4 oz.o, 50c; oz., \$1.50; $1 / 4$ llb., \$4.50, postpaid. One of the best varieties for the Northwest; early and superb quality. Our strain has been carefully selected and we know it will please you.

172 Veitch's Autumn Giant-Pkt., 10c; 1/4 oz., 25c; oz., $75 \mathrm{c} ; 1 / 4$ 1b., $\$ 2.00$, postpaid. A large vigorous growing late variety. The heads are large, firm, beautifully white and well protected by the large leaves.

Cress (Pepper or Tongue Grass)-Sown with White Mustard makes an excellent Salad, most refreshing used in bread sandwiches.

210 Extra Curled-Pkt.o 5e; oz., 10c; 1/4 lb., 30c; lb., 75e, postpaid. A distinct compact growing variety, leaves deeply cut and curled at the edges. Charming pungent flavor.

211 Water - Pkt., 10c; oz., 45c; 1/4 lb. \$1.50, postpaid. A distinct Cress, thriving best in moist positions, or in brooks or ditches, where its roots and stems are submerged. Makes a delicious and appetizing salad.

\section{CARR0T-Continued}

rly Scarlet Horn-Pkt., Je; oz., 10c; $1 / 4$ 1b., 30c; $1 \mathrm{~b} ., \$ 1.00$, postpaid. Roots inches long; color orange red, inclined to be blunt rooted, splendid for 163 oxheart-Pkt., 5c; oz., 10c; 1/4 1b. 1b., 80c, postpaid. Very short and four and one-half to five inches 164 St. Valery Long Red-Pkt., 5c; oz., 1/4 lb., 25e; lb., 70c, postpaid. Roots point; flesh thick, sweet and tender, suit-

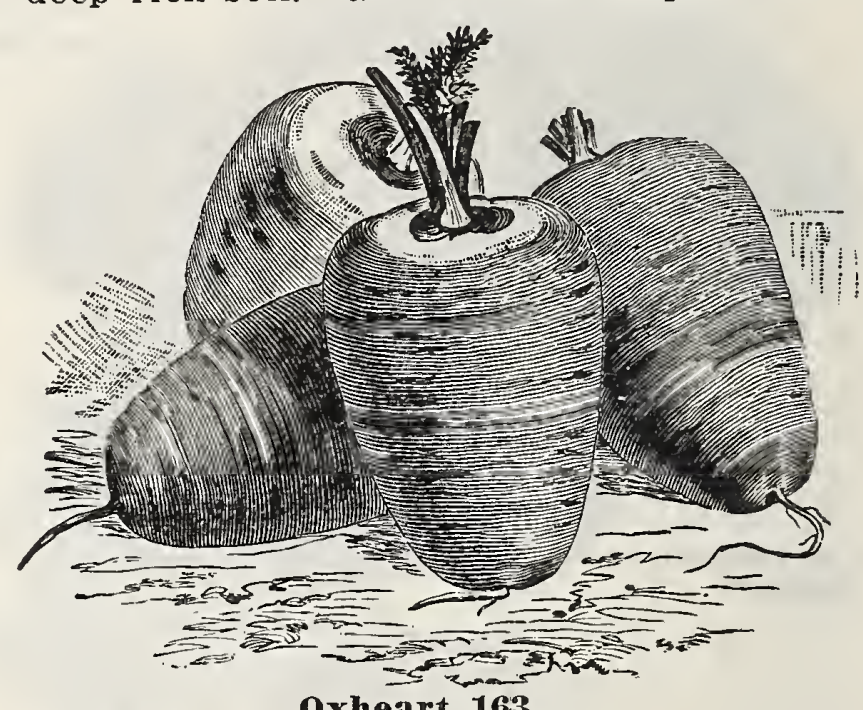

Oxheart 163

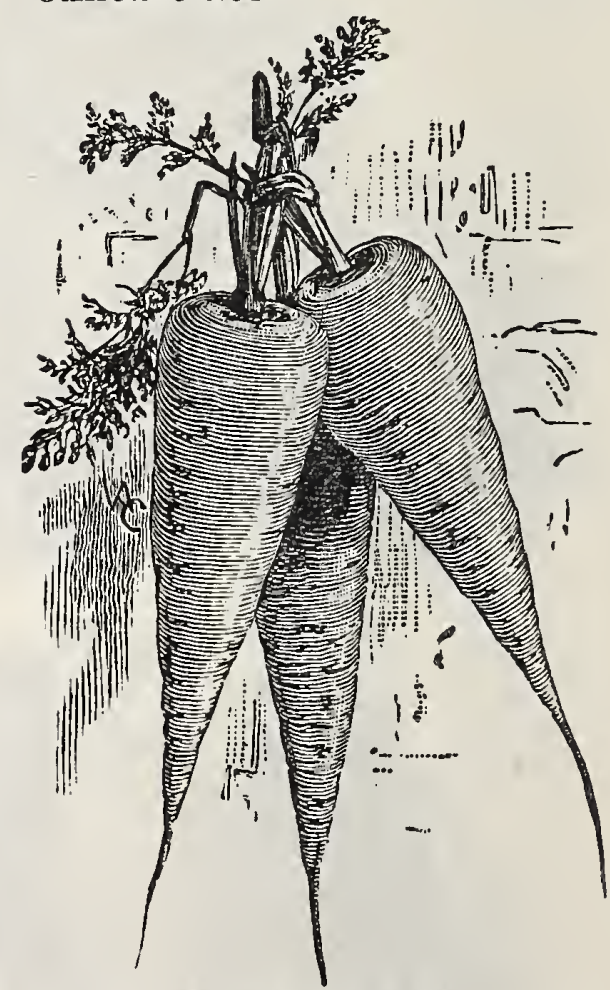

St. Valery 164
Watercress contains much iron, and is a real blood medicine. People who desire a good complexion should eat it abundantly; it is a destroyer of pimples and a cleanser of the entire system. Watercress will neutralize chalk in the blood, which is a cause of ageing and stiffening of the fibres.

This sign "DISC0" stands for highest quality in seeds. 


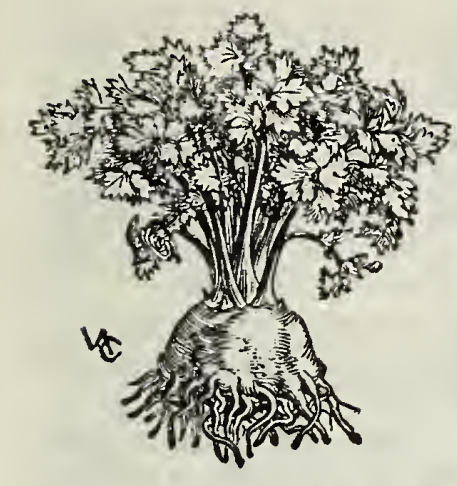

Turnip Rooted 190

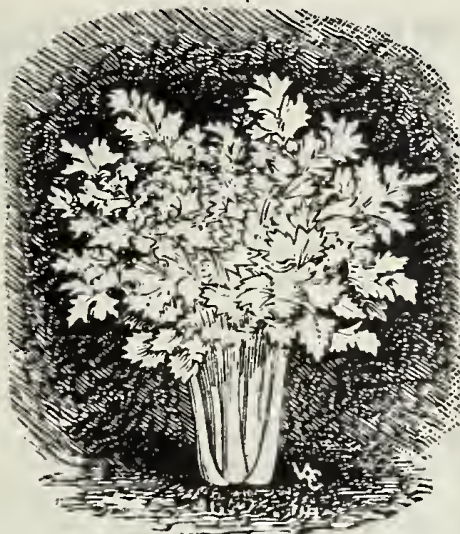

White Plume 182

\section{Celery}

Should be in every garden. Eat lots of Celery, either cooked or raw, and you

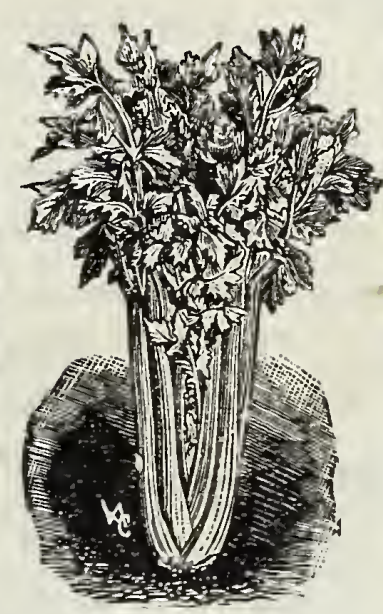

Giant Pascal 180

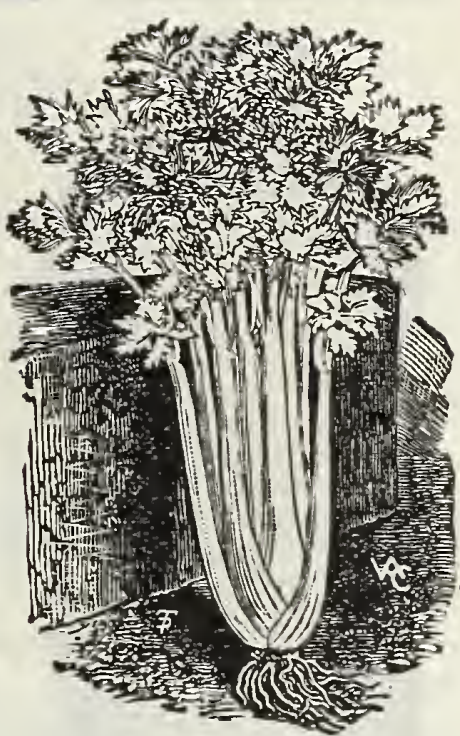

Golden Self Blanching 181

180 Giant Pascal-Pkt., бc; 1/2 oz., 10c; oz., 15c; 1/4 lb., 50c; lb., \$1.60, postpaid. Vigorous growing compact, productive variety. Stalks short, broad, very thick, crisp and tender, blanching readily to a yellowish white color. A very good keeper and one of the best for winter use. See illustration.

181 Golden Self Blanching-Pkt., 5c; 1/2 oz., 15c; oz., 25c; 1/4 lb., 80c; lb., \$2.75, postpaid. French variety introduced in 1883. It is undoubtedly the finest early celery in cultivation. It is perfectly solid, of a fine nutty flavor, attains $\approx$ good size, and when blanched is of a handsome golden yellow color. See illustration.

182 White Plume Improved-Pkt., 5c; 1/2 oz., 10c; oz., 15c; 1/1 lb., 50c; lb., \$1.60, postpaid. Distinguished by the silver white color of its inner leaves. A very early handsome våriety, easily blanched, a beautiful white color. The most popular sort in the Northwest. See illustration.

190 Celeriac or Turnip Rooted Celery-Pkt., 5c; 1/2 oz., 10c; oz., 15c; $1 / 4$ lb., 50c; lb., $\$ 1.75$, postpaid. Develops instead of the usual stalks, a broad coarse root, which is much esteemed as a vegetable for flavoring soups. Very hardy and will keep all winter if properly stored. See illustration.

\section{Sweet Corn}

Sweet Corn ought to be more extensively grown than it is, occupying as it does such an important place among vegetables, being wholesome, nutritious, and healthful.

\section{FIRST EARLY VARIETIES}

221 Golden Bantam-Pkt., 10c; 1/2 lb., 15c; lb., 25c; 5 llos., $\$ 1.00$, postpaid. By express, 10 lbs. or more, at $18 \mathrm{c}$ per lb. Early; golden yellow in color, of highest quality. Ears six to seven inches long. Our stock has been most carefully selected. See illustration.

222 First and Best-Pkt., 10c; 1/2 lb., 15c; lb., 25c; 5 llos., \$1.00, postpaid. By express, 10 lbs. or more, at isc per lb." One of the earliest maturing varieties on the market: beautiful white color. For such an early variety, produces a wonderfully large ear. Beautiful quality.

22:3 Early Mammoth White Cory-Plit., 10c; 1/2 lb., 15c; Ib., 22c; 5 lbs., \$1.00, postpaid. By express, 10 lbs. or more, at 15e per lb. The earliest and best of all extra early sweet corn. Ears ten to twelve rowed: seven to eight inches long; very sweet, tender and white. If you have not tried this do so, it will certainly please you.

224 Whipple's Early-Pkt., 10c; 1/2 lb., 15̃c; lb., 25̃e; 5 lbs., \$1.00. postpaid. By express, $10 \mathrm{lbs}$. or more, at $18 \mathrm{c}$ per lb. This variety selected and introduced by the celebrated Corn Raiser, Mr. Whipple Yellow variety, somewhat similar to Golden Bantam or Buttercup, but is earlier than either of these varieties; is equal in quality and the ears are much larger than Golden Bantam. From trials we have seen of these varieties, we believe that it is destined to become very popular, suitable both for market or home use.

\section{SECOND EARLY VARIETIES}

225 Early Crosby-Pkt, 10c; $1 / 2$ lb, 15c; 1b, 22c; 5 lbs, $\$ 1.00$, postpaid. By express, 10 lbs. or more, at 15c per $1 \mathrm{~b}$. The standard and popular variety; twelve-rowed with ears seven inches long; the grains are short and square, beautifully white, sweet and tender. One of the most popular second early varieties.

226 Howling Mob-Pkt., 10c; $1 / 2$ 1b., 15c; lb., 22c; 5 lbs., \$1.00, postpaid. By express, 10 lbs. or more, at 15c per lb. It is said that this variety received its name because of the fact that when the original grower brought cobs into the market to sell, so popular had they become that the crowds who pressed forwald to his stand to secure their supplies, represented literally a howling mob.

Ears are from nine to ten inches long; sixteen-rowed, of a beautiful white color and of excellent quality; a good sort for general use, both for the home garden and also for the market grower.

231 Bantam Evergreen-Pkt., 10c; 1/2 lb., 15c; lb., 28c; 5 1bs., \$1.25, postpaid. By express, $10 \mathrm{lbs}$. or more, at $20 \mathrm{c}$ per $1 \mathrm{~b}$. A cross between Golden Bantam and Stowell's Evergreen. The ears grow about eight inches long, twelve to fourteen-rowed, matures with Howling Mob; the kernels are broad and deep, of a rich golden yellow color.

You cannot beat our Dakota grown Sweet Corn.

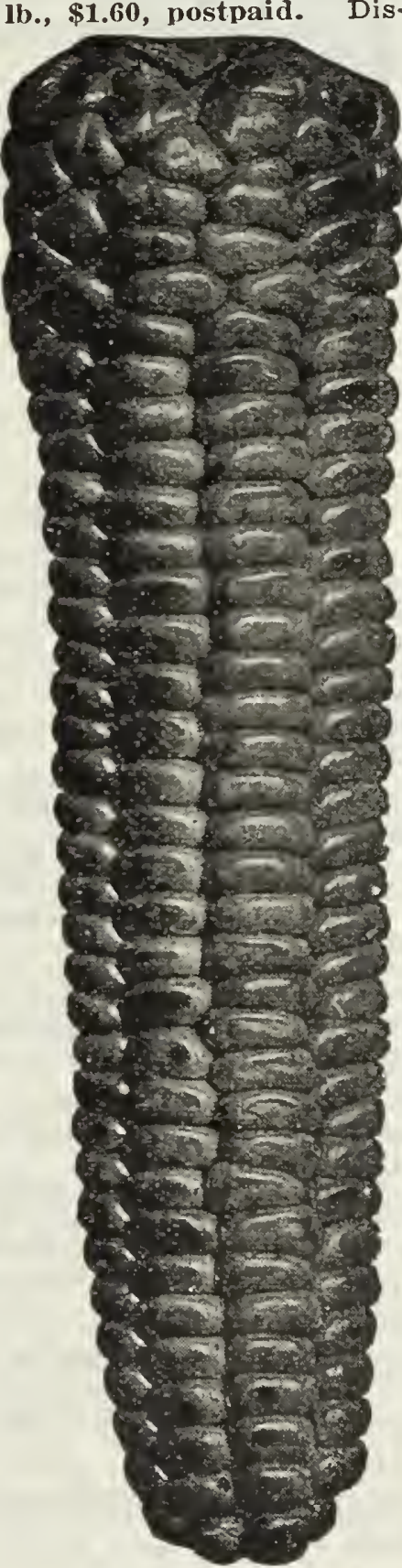

Golden Bantam 221 


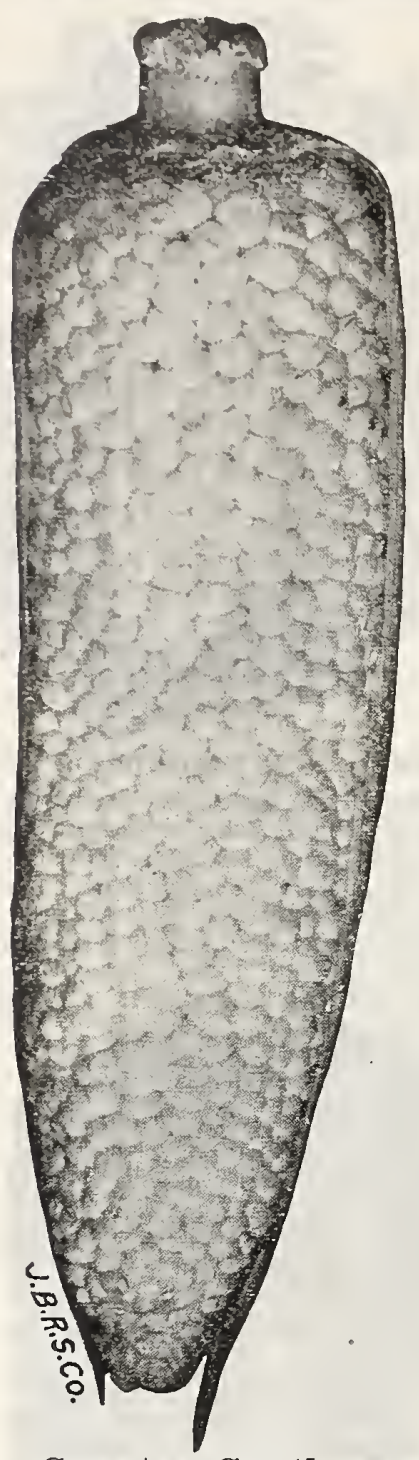

\section{SWEET CORN-Continued MAIN CROP VARIETIES}

297 Black Mexican-Plkt. 10c; $1 / 2$ 1b. 15c; 1b. 23e; 5 lhs. \$1.00, postpaid. Hy express, 10 lbs. or more, at $16 \mathrm{c}$ per $1 \mathrm{~b}$. This famous old variety which will be remembered because of its unusual sweetness and delicate flavor has been much improved by selection, and the stock we now offer is sufficiently early and hardy to be grown with perfect success anywhere in the United States.

This corn when ready for the table is a beautiful clear white, but when the grain is ripe it is a peculiar black or bluish black. We recommend this as the most desirable Main Crop Variety.

228 Country Gentlemen-Plkt. 10c; 1/2 1b. 15c; 1b. 23e; 5 lbs. $\$ 1.00$, postpaid. By express, $10 \mathrm{lbs}$. or more, at $16 \mathrm{e}$ per $1 \mathrm{~b}$. In this standard variety the acme of perfection and quality is obtained. The ears are from 8 to 9 inches long; the cob is small, white in color and densely covered with long, white, slender grains. The formation is peculiar inasmuch as the grains are not formed on the cob in regular row formation, but are closely packed together without any apparent order. It is a heavy cropper and owing to its unusual heavy husk, it is protected in such a manner that it retains its tenderness and keeps in the "milk stage" for an unusually long time.

229 Stowell's Evergreen-Plkt. 10c; 1/2 1b. 15c; 1b. 22c; 5 lbs. \$1.00, postpaid. By express, 10 los. or more, at 14c per lb. The best known Sweet Corn. Ears 8 to 9 inches long, 16 to 18 rowed, with a very deep sweet grain. Our strain is unusually good.

230 White Rice Pop Corn-Pkt. 10e; 1/2 1b. 12c; 1b. 20c; 5 1bs. 80c, postpaid. By express, $10 \mathrm{lbs}$. or more, at 10e per lb. The earliest of the popping varieties and the only one that can be successfully grown in the middle and northwest. For corn for popping, see inside back cover.

\section{Country Gentleman 228}

\section{Cucumber}

Fresh cucumbers gathered from your own patch are just as different as chalk is to cheese from those half wilted fruits which you buy in the store. Moral-Grow your

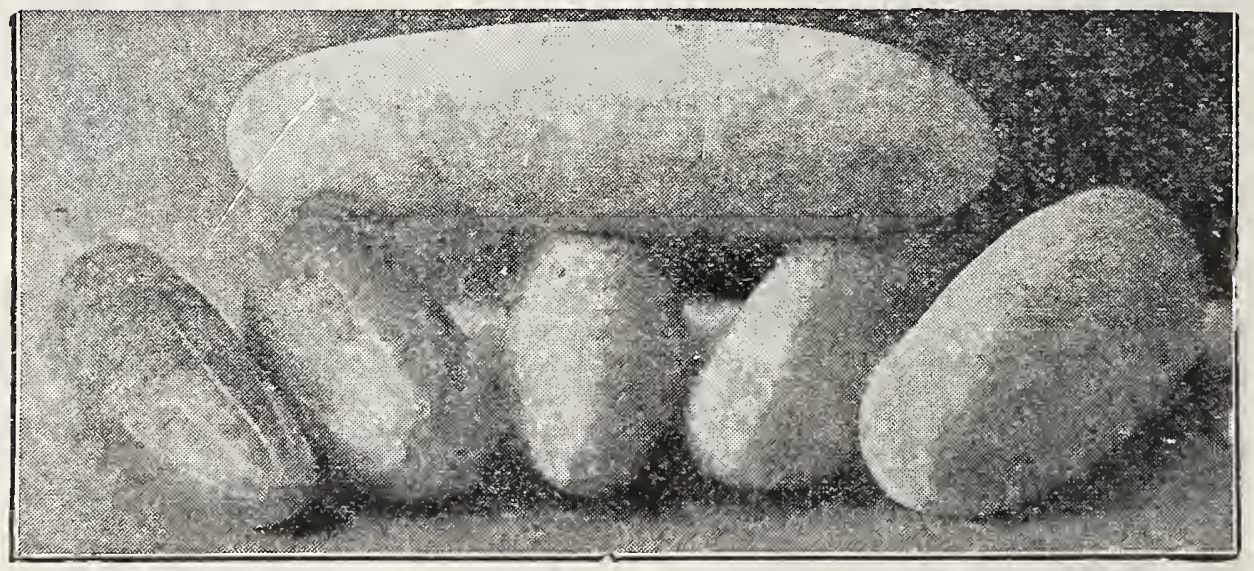

Early Fortune, Cool and Crisp and Long White Spine

239 Earliest of All-Pkt. 5e; oz. 10c; 1/4 1b. 35c; 1b. \$1.00, postpaid. The earliest White Spine variety in cultivation. One week earlier than Early Fortune, should be used for first crop.

240 Extra Early Russian-Pkt. 5c; oz. 15c; 1/4 1b. 45c; 1b. \$1.45, postpaid. The earliest cucumber in cultivation, hardy and productive; fruit very small.

241 Early Fortune-Plkt., 5c; oz. 10c; 1/4 1b. 35e; 1b. \$1.10, postpaid. The finest type White Spine yet produced. Early, very productive and disease resistant; fruits 9 inches long; slightly tapering; flesh white, very firm and crisp, with very few seeds; color rich dark green. Splendid shipping variety. See illustration.

242 Chicago Pickling -Pkt. 5e; oz. 10e; 1/4 1b. 35e; 1b. \$1.00, postpaid. The most popular and excellent pickling sort, very uniform, productive and of good color; hardy and early.

243 Cool and Crisp-Pkt. 5c; oz. 10c; 1/4 1b. 35e; 1b. \$1.00, postpaid. A white spine type; early; pointed at both ends; good quality for slicing, but no use for pickling. See illustration.

244 Extra Long. White Spine-Pkt. 5e; oz. 10c; 1/4 1b. 35c; 1b. \$1.00, postpaid. The largest of the White Spine family; fruit long, thick and tapering to both ends, crisp and solid, a fine slicing sort; color light green. See illustration.

245 Japanese Climbing-Pkt. 5c; oz. 10c; 1/4 1b. 35e; 1b. \$1.10, postpaid. A distinct climbing sort for covering fences or trellises; fruit 10 inches long, thick, crisp and fine quality; color dark green.

246 Early Frame or Short Green-Pkt. 5e; oz. 15e; 1/4 1b. 45e; 1b. \$1.40, postmaid. Medium sized, vigorous growing and productive variety. Good for both pickling and slicing.

247 Cucumber Long Green Improved-Pkt. 5e; oz. 10c; 1/4 1b. 35e; 1b. \$1.10, postpaid. Well known table variety grows 12 to 14 inches long, tapering towards the stem; end color dark green; flesh white and firm. Our stock is very superior.

248 Davis Perfect-Pkt. 5c; oz. 10c; 1/4 1b. 35c; lb. \$1.05, postpaid. An extra long; dark green type of White Spine, retains its color and good qualities long aftel being picked; the flesh is crisp and solid. 
Egg Plant Not so easily grown as Cucumbers, well worth the trouble.

250 Early Long Purple-Pkt. 5c; oz. 40c; 1/4 lb. \$1.50; $1 \mathrm{lb} . \$ 5.00$, postpaid. One of the earliest, most hardy and productive sorts; fruits 6 to 8 inches long; rich purple and fine quality.

251 New York Improved Purple-Pkt. 5c; oz. 40c; 144 lb. $\$ 1.50 ; 1 b$. $\$ 5.00$, postpaid. This variety has long been a favorite with market growers. The plant grows to a large size; of a spreading nature and absolutely spineless. Each plant will usually produce 4 to 6 large oval fruits of dark purple color. The quality being second to none. For main crop, we heartily recommend this excellent variety. Endive Excellent for salad; easily grown and

255 Green Curled-Pkt. 5c; 0z. 10c; 1/4 lb. 30c; 1 b. $\$ 1.00$, postpaid. One of the best varieties for general use; the heads grow very close, leaves forming a dense mass and being finely curled.

Garlic-See page 28.

\section{Kale or Borecole}

Excellent for late greens, is also much relished by poultry; improved by a touch of frost.

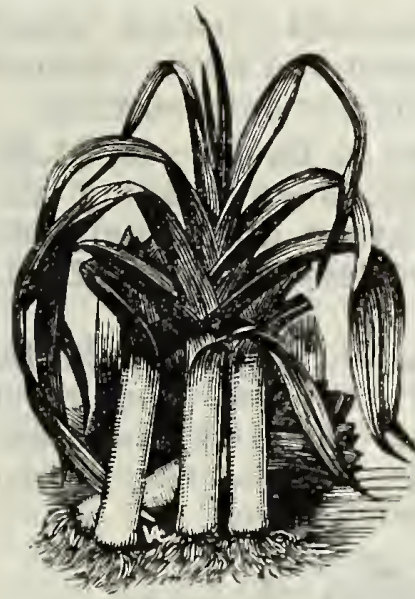

Leek, American Flay L e e $\mathbf{k}$

260 Iwarf Green Curled Scotch-Pkt. 5c; oz. 10c; 14 lb. 30c; lb. $\$ 1.00$, postpaid. Grows 1 to $1 \frac{1 / 2}{2}$ feet high, spreading growth, leaves intensely curled.

\section{Koli Rabi Turnip Rooted} C a b b a g e Bulbs grow ab ove cooked like turnips, but are much sweeter and finer flavor.

270 Early White. Vienna-Pkt. 5c; oz. $20 \mathrm{c} ; 1 / 4$ lb. 60c; lb. $\$ 2.00$, postpaid. Best for garden cultivation, early, dwarf top, fine quality. For field variety see Field Roots, page 15.

290 Large American Flag-Pkt, 5c; oz. 15c; 14 Ib. 60c; lb. $\$ 2.00$, postpaid. The most popular variety with gardeners everywhere; of strong growing habit, very broad leaved. If earthed up blanches beautifully, forming excellent long white plants which are a delight to the cook.

\section{Lawn: Grass}

907 DISC0 Evergreen Lawn Grass-Nothing adds so materially to the charm and distinguishes a home from a house on a vacant lot, than does a well-kept lawn. This not only applies to the suburban residence in the city, or residence in the smaller towns, but applies with equal force to the farm. We venture to say that nothing would so materially improve and maintain our home-life as an improvement in the surroundings of the averáge farm home. - The tendency is to spend money on automobiles to take the children away from home rather than make the home and surroundings so attractive that their desire will be to stay around home. That this is desirable from every standpoint cannot be gainsaid. We have had long experience in the preparation of lawn grass mixtures, and DISC0 Evergreen Mixture represents the very finest combination of dwarf and close growing grasses which will form in a remarkably short time, a soft, velvety turf. Our advice is gladly at your service in seeking to help you, to establish a good lawn.

1 Ib. 35c; 10 lbs. $\$ 3.45 ; .25$ lbs. $\$ 8.50 ; 50.1 b s . \$ 16.75 ; 100$ lbs. $\$ 33.00$. Postage or express extra.

Our Lawn Grass is famous, for the splendid results obtained. 


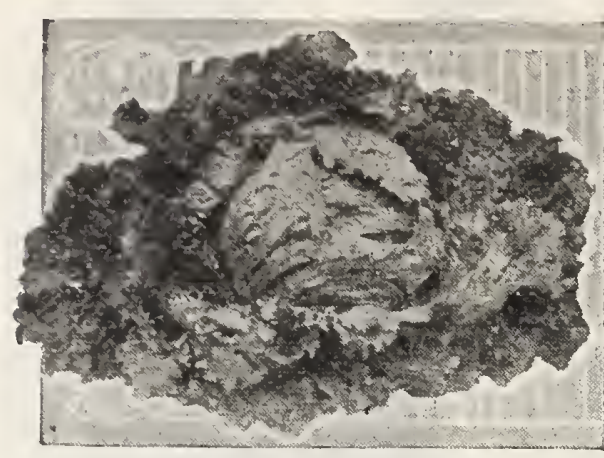

Big Boston 301

Lettuce In hot weather lettuce is always welcome on the table and nothing beats a few heads fresh pulled from your own garden.

301 Big Boston-Pkt. 5c; 0z. 10c; 1/4 lb. 35c; lb. $\$ 1.00$, postpaid. Very popular for outside culture as well as cold frame forcing. Head large and compact, leaves broad, almost smooth, color light green, slightly tinged reddish-brown; heart greenish-white, tinged yellow of good quality.

302 California Cream Butter-Pkt. 5c; oz. 10c; 34 Ib. 35c; lb. $\$ 1.00$, postpaid. Plant compact, heads large, globular and very firm; leaves broad, crurnpled and very thick; color dark, glossy green, freely spotted deep brown; the heads blanch a beautiful creamy yellow; quality the best.

303 Grand Rapids-Pkt. 5c; oz. 10c; $1 / 4$ lb. 35c; lb. $\$ 1.00$, postpaid. The favorite loose-leaved forcing lettuce; does well in the Northwest for early planting outdoors. Leaves short, spatulate in shape, excessively crumpled, and the border heavily fringed; color very light green, with no trace of brown. A most handsome and attractive lettuce.

304 May King-Pkt. 5c; oz. 10c; 14́4 1b. 30c; 1b. \$1.00, postpaid. A handsome, extremely early, compact heading variety; leaves light yellowish green, tinged reddish brown, while the heart blanches a rich golden yellow.

305 Tennis Ball-Pkt. 5c; 0z. 10c; 1/4 lb. 25c; lb. 80c, postpaid. A very reliable, adaptable, sure heading sort;

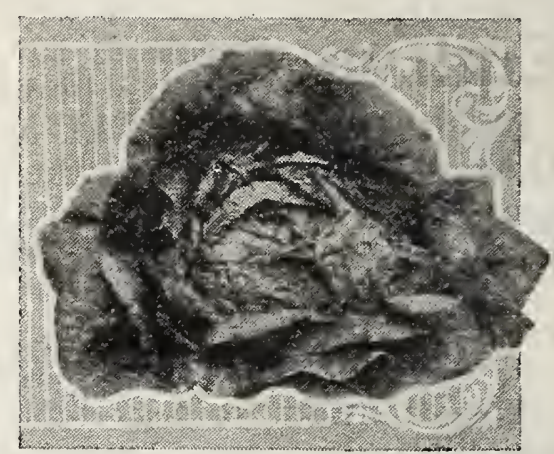

California Cream Butter 302

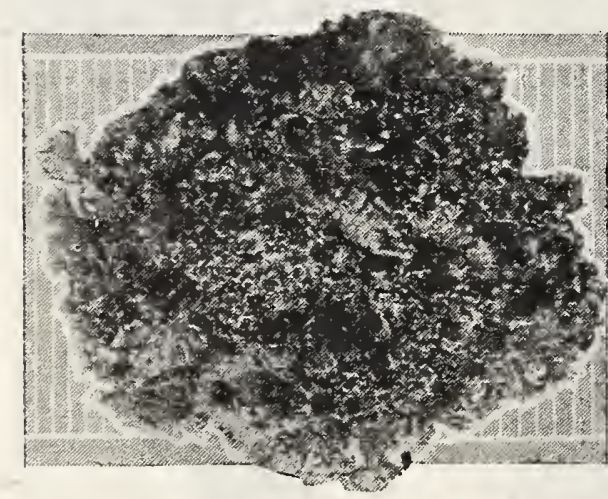

Grand Rapids 303 heads globular, firm and well blanched; leaves broad and much crumpled; color light green and never spotted brown; finest quality; very suitable for late sowing.

306 Way-a-head-Pkt. 5c; oz. 15c; 14 lb. 40c; lb. $\$ 1.20$, postpaid. A very early, handsome, sure heading variety; the outer leaves are light green and crumpled; the inner head blanches a rich buttery-yellow; of superior quality.

308 Black-seeded Simpson-Pkt. 5c; oz. 15c; 1/4 lb. 35c; lb. \$1.10, postpaid. One of the best and most popular large early loose heading varieties, succeeding everywhere, and always reliable. Leaves very broad and crumpled. Color, light yellowish-green.

309 Prizehead-Pkt. 5e; oz. 10c; $1 / 4$ 1b. 25e; 1b. 80c, postpaid. A crisp and tender loose-leaved, nonheading variety, deservedly popular. Color, medium green, shading to brown.

307 White Paris Cos-Pkt. 5c; oz. 10c; 1/4 1b. 30c; 1b. \$1.00, postpaid. Smooth, long, narrow, upright leaves and blanches nicely when tied up; color dark green; quality fine; self folding.

Mushroom Spawn so difficult to grow as many people imagine, and as they represent such a real table delicacy, we a $n t$ i c i p a t e their being grown much more extensively. A simple plan is to break up a brick in pieces the size of a pigeon's egg and put under the sod here and there in the pasture.

You will be surprised at

the results. Cultural instructions supplied with every order.

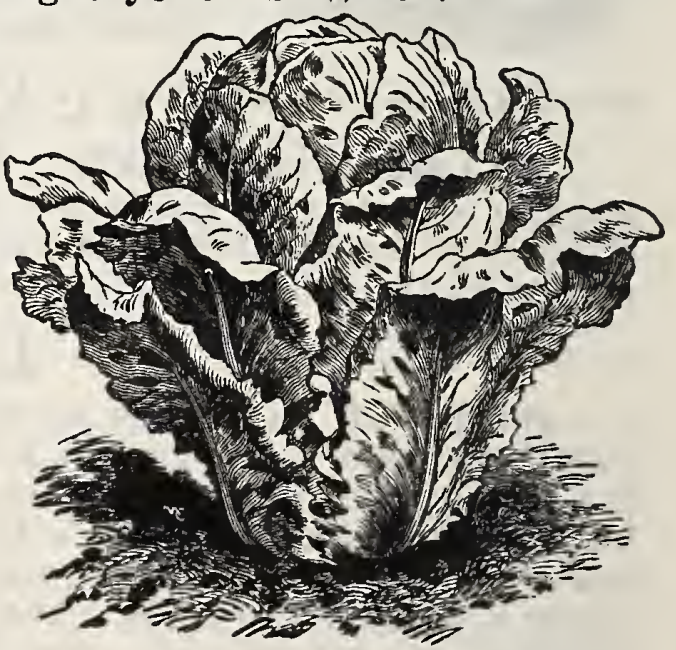

White Paris Cos 307 355 Lambert's Pure Culture-40e a brick, postpaid. By express; brick, 30c; 5 bricks, \$1.35; 10 bricks, \$2.50; 25 bricks, \$4.75. Recent trials have shown this spawn to give much better results than the English stock, no doubt owing to its being fresher and the spawn more vigorous.

Mustard A most delicious and pungent Salad; best used in conjunction with Curled Cress, 350 Finest white-Pkt. 5e; oz. 15e; 1/4 1b. 30c; 1b. 75e, postpaid. Very pungent and appetizing Salad.

Sow Lettuce Generonsly, the Return Will Pay You. 


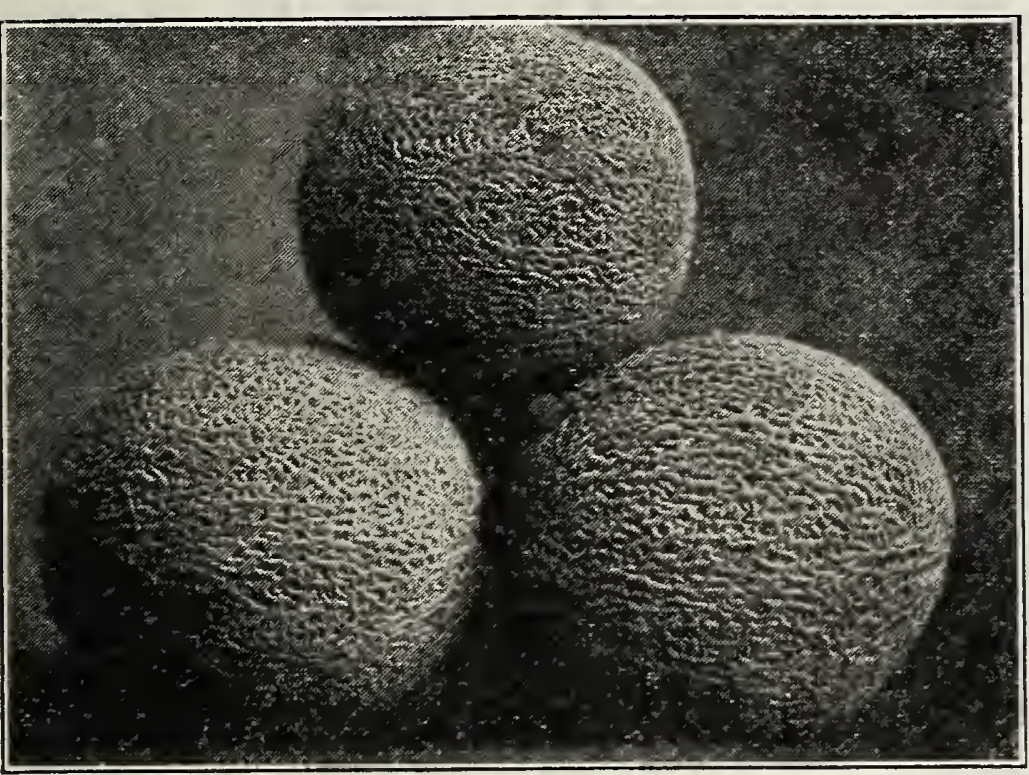

Montreal Green Nutmeg 323
323 Montreal Green NutmegPkt. 5c; oz. 15c; $1 / 4$ lb. 40c; $1 \mathrm{~b}$. $\$ 1.50$, postpaid. This variety is possibly famed more than anything else for the unusual size to which it can be $\mathrm{grown}$; fruits weighing 18 to 20 pounds, being quite common. The fruits are round, flattened at both ends; med i u m green color, $r$ ib b e d and netted; the flesh is remarkably thick and of superior quality.

324 Petoskey or Paul RosePkt. 5c; 0z. 10c; 1/4 lb. 30c; lb. 90c, postpaid. Oblong in shape; color deep green, slightly ribbed, netted thick flesh; of a deep salmon color, excellent $q u$ a lity; grows to a popular size for market use and is an excellent shipper.

\section{Musk Melon}

We pride ourselves that our strains of Musk Melon are the very finest possible. The selection we offer contains the very best of the Early, Medium and Main Crop Varieties.

319 Emerald Gem-Pkt. 5c; oz. 10c; 1/4 Ib. 35c; lb. $\$ 1.25$, postpaid. A choice variety, the fruits being deep emerald green in color; globular or slightly flattened shape; distinctly ribbed and lightly netted; the flesh being unusually thick, sweet and of a deep, rich salmon color; the seed cavity being very small. This is an excellent variety for home use and for the local market, but we do not recommend as a shipping variety.

320 Extra Early Knight-Pkt. 5c; oz. 10c; $1 / 4$ lb. 35c; lb. $\$ 1.20$, postpaid. An extremely early medium sized melon; the fruits being oblong; distinctly ribbed and closely netted; the flesh being fairly thick and very sweet; the color medium green blending to light pink. One of the best melons for the Northwest, and an excellent shipper.

321 Honey Dew-Pkt. 5c; oz. 15c; 1/4 1b. 40c; 1 . $\$ 1.30$, postpaid. This comparatively new variety is rapidly gaining in popularity and bids fair to become one of the most generally grown sorts. The fruits are large, oval shape, generally about 10 inches long and 8 inches in diameter; surface is smooth and hard without ribbing or netting; creamy white in color; the flesh being a light emerald green, very thick and ripening right to the rind. The quality of this melon leaves nothing to be desired. It keeps well and is an excellent shipping sort.

322 Jenny Lind-Pkt. 5e; oz. 15c; $1 / 4$ lb. 40c; Ib. $\$ 1.20$, postpaid. An old favorite unusually early, small, green fleshed; the fruit is round, flattened at ends, ribbed and netted. For an early variety the flesh is very attractive in flavor and quality.

325 Banana-Pkt. 5c; oz. 15c; 1/4 lb. 45c; 1b. $\$ 1.40$, postpaid. When growing, just looks like a great big Banana, grows about $21 / 2$ feet long, flesh of a deep salmon color, quality very fine. Some excellent specimens were brought into us by our customers last summer.

326 Rockyford-Pkt. 5c; oz. 10c; 狧 lb. $30 \mathrm{c} ; 1 \mathrm{~b}$. $\$ 1.00$, postpaid. One of the mos! popular varieties of Musk M e l on. Our strain is an exceptionally good one. The fruit is small, a $1 \mathrm{~m}$ o s t r o u n d, perfectly smooth, showing no ribs, flesh thick and deep green, showing a faint lining of pink and gold at the center. The quality is of the best.

327 Pollock's No. 25-Pkt. 10c; oz. 15̌c; 14 1b. $45 c$; 1b. $\$ 1.25$, postpaid. Very similar to Rockyford except that the flesh is salmon colored. For those who prefer this to the green flesh, we recommend this variety.

328 Extra Early 0sage-Pkt. 5c; oz. 10c; $1 / 4$ lb. 35c; lb. $\$ 1.00$, postpaid. A distinct improvement on the old type of Osage, being also a week to ten days earlier. Fruit dark green; flesh, rich orange salmon. One of the best for general use.

Mitchell has become quite famous as a shipping center for Melons. Fruits of the finest quality are shipped out in car load lots, and the industry promises to become very lucrative for the farmers of the district. Our sales of both Musk Melon and Water Melon Seed were phenomenal and all who used them were satisfied.

Sow our Hardy Northern Grown Seed for Best Results. 


\section{Water Melon}

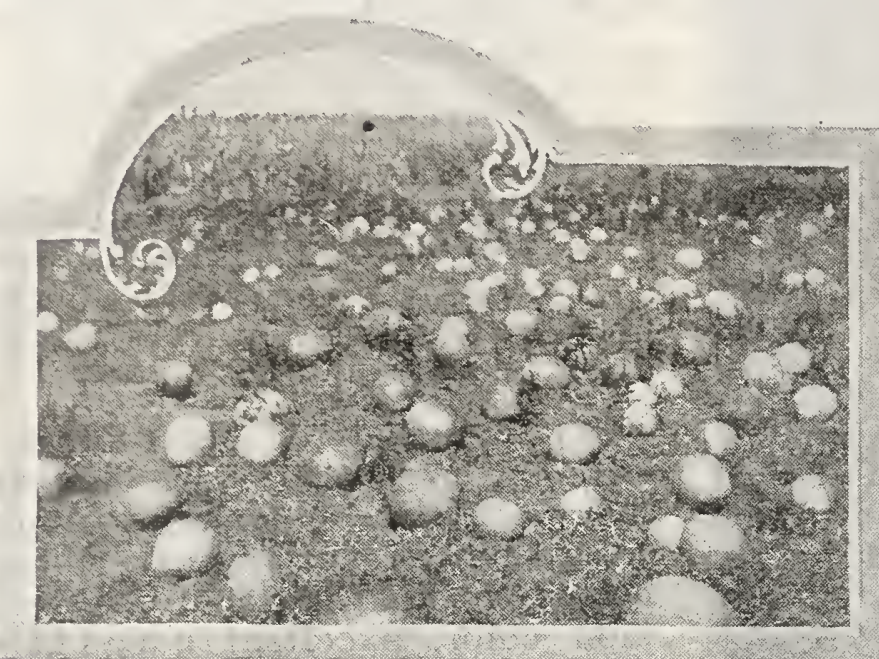

Water Melons galore now a familiar sight in the vicinity of Mitchell

As with Musk Melon, we exercise the greatest care to insure that our stocks will be of the very finest possible quality.

330 Citron, Colorado Preserving-Pkt. 5e oz. 10c; $1 / 4$ lb. 25e; 1b. 75e, postpaid. A decided improvement on the old Preserving Citron; seeds are green; the shape of the fruit is roundish oblong; very early; hardy and productive.

331 Citron, Red Seeded-Pkt, 5e; oz. 10c; $1 / 4$ 1b. 25c; lb. 90c, postpaid. In many respects this is similar in quality and productiveness to the Green seeded Variety. We find, however, that some growers prefer the one, while others show a preference for the other. Our experience is that there seems to be very little difference, excepting in the color of the seed. For the purpose of suiting all tastes, however, we carry both types.

332 Cole's Early-Pkt. 5c; oz, 10c; 1/4 11, 25e; 1b. 75c, postpaid. One of the earliest very hardy of medium size, nearly round, rind dark green, striped a lighter shade; flesh deep pink and excellent in quality.

333 Peerless or Ice Cream-Pkt. 5c; oz. 10e; $1 / 4$ 1b. 25e; $1 \mathrm{~b}$. 75e, postpaid. Very early, of medium size, and one of the best for the Northwest, short, oblong in form; rind thin light green; mottled and finely veined with a darker shade; flesh bright scarlet and very sweet.

334 Round Light Icing-Pkt. 5c; oz. 10c; 1/4 1b. 25c; 1b. 85c, postpaid. This variety, while not as early as Cole's Early, is sufficiently early to insure its ripening in any state in the Northwest or even in Canada. It grows to a fair size, is nearly round; the flesh is a beautiful bright red, while the rind is a very light green; the quality is excellent.

325 Tom Watson-Pkt. 5c; oz. 10c; $1 / 41 \mathrm{~b}$. $25 e ; 1 b .75 c$, postpaid. In our opinion this is the best shipping melon on the market, and second to none as a Main Crop Variety; produces large size fruits; color a medium green; flesh a rich red and of excellent quality. We recommend our strain of this variety as being second to none, and suggest that this be used as the Main Crop sort.

336 Kleckley's Sweet-Pkt. 5c; oz. 10c; 1/4 1b. 30c: lb, 90c, postpaid. This melon did very well with many of our customers last season; it grows to a fairly large size, is medium early and exceedingly sweet, oblong in shape, rind very dark green, flesh bright rich red, white seeded. Not recommended for shipping but excellent for home use.

\section{"Disco" Northern Grown Seed Potatoes}

\section{Write for our special quotations on potatoes, car lots or less.}

The potato crop should occupy a more prominent place than it does. With the advent of improved machineny, for planting, digging and loading into wagons, the labor difficulty has been materially reduced. To obtain best results, it is necessary to change frequently and get selected northern grown stock which has been specially grown for seed purposes. The varieties we offer have been carefully tested, are heavy croppers and good quality.

770 Certified Irish Cobbler-Said to have been raised by an Irish shoemaker and he sure knew a good potato. One of the most universally grown potatoes, popular from Coast to Coast. Strong grower, deep eyes, hardy constitution, tubers roundish, flattened somewhat at ends; skin creamy white, foliage deep green, flowers purple; early, good cropper and splendid quality.

771 Certified Early Ohio-One of the earliest varieties grown; tubers round, oblong; skin light pink; deeper in color at seed end, eyes numerous, but shallow. Flowers white. Quality good.

780 Potato Eyes-For those who desire to get a new strain of potatoes, particularly in outlying districts, where freights are high and transportation is slow, we confidently recommend Potato Eyes. We guarantee their safe arrival in good condition for planting. If, for any reason they cannot be planted, immediately on arrival, they should be spread out thinly and covered with soil. This will retain their vitality, and if carefully planted, they will not suffer. 100 Eyes, 50 each of both varieties, $\$ 1.25$, postpaid. Wither variety of Eyes, 50c per 25 eyes, postpaid. 
Onion The onion is one of the most important crops in cerned; it is also Northwest, so far as regetables are coneither raw or cooked.

There is a vast difference in the quality of different stocks of Onion Seed. Our Onion Seeds are all grown from choice selected bulbs and can be depended upon to give the best results. Our seed is all new crop of strong vitality. Beware of low priced old seed of poor germination and weak growth.

360 Prizetaker-Pkt. 5c; 0z. 25c; 1/4 1b. 75c; lb. $\$ 2.50$, postpaid. One of the largest onions grown and the mildest, a sure cropper, globe shaped, color light straw, highly recommended.

361 Australian Brown-Pkt., 5c; 0z. 20c; 1/4 1b. 45c; lb. $\$ 1.50$, postpaid. Noted for its keeping qualities and productiveness; the color is quite distinct; very early, semi globe shaped; should be given a trial in every northwestern garden.

362 Danver's Yellow Globe-Pkt. 5c; oz. 15c; 1/4 1h. 50c: Ib. $\$ 1.75$, postpaid. One of the most popular and extensively grown varieties in the Northwest and deservedly so; the outer skin is reddish brown, lemon colored underneath; medium size; very early; and a good keeper.

363 Large Red Wethersfield-Pkt. 5c; oz. 20c; 1/4 lb. 60c; 1b. $\$ 2.00$, postpaid. Probably the oldest and best known type of onion. A fine large, handsome, variety, with bright red colored somewhat flattened bulbs and purplish white flesh. Very productive and a good keeper.

364 Southport Red Globe-Pkt. 5c; oz. 20c; 14 1b. 60c; Ib. $\$ 2.00$, postpaid. The finest type of red onion in cultivation; perfect globe shaped with a small neck; excellent keeper;

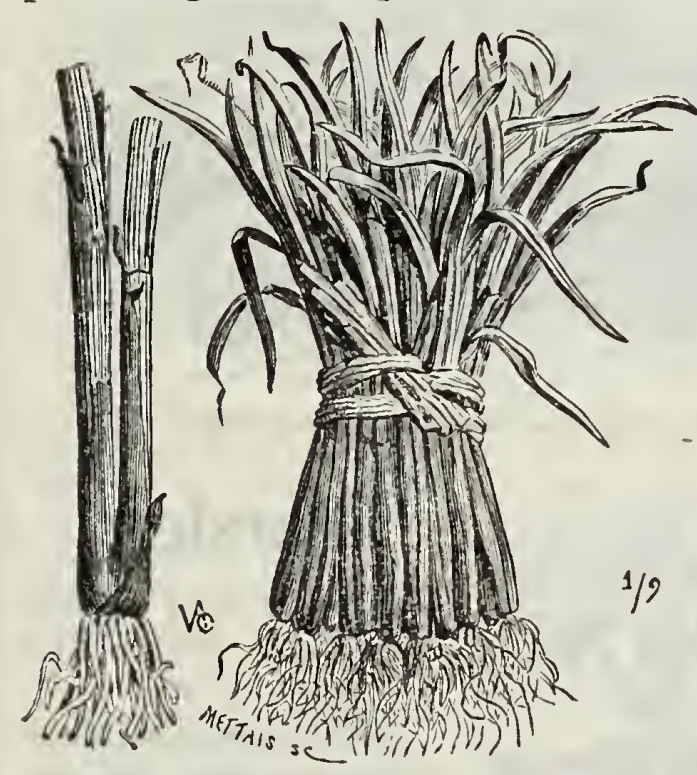

Onion White Welsh 385

385 White Welsh-Pkt. 5c; oz. $35 \mathrm{c} ; 14$ 1b. 90c, postpaid. Does not form a bulb like other onions but only a small enlargement at the base of each shoot. Good for bunching. Ready for use very eraly in the spring, comes up every year.

\section{Pickling Varieties}

382 White Barletta-Pkt. 5c; oz. 30c: 1/4 1b. 90c; lb. $\$ 3.00$, postpaid. Bulb small, beautiful white color, flat on top and conical at the bottom. Extremely early and a most valuable pickling sort.

383 Silverskin-Pkt. 5c; 0z. 25c; 1/4 lb. 75c; Ib. $\$ 2.25$, postpaid. This variety is is particularly good. som e w a t flattened in shape; the flesh is white and mild.

Sonthport Y e $110 \mathrm{w}$ trobe- oc; 0z. 15c; 1. 10. 50c; Il. \$1.75, postkis. A beautiful globe shaped onion, color deep and heavy thick skin, flesh white, crisp and mild in flavor, excellent shipping sort.

381 Southport Wh it e Globe-Plit. 5c; oz. 25c; 14 1h. $85 \mathrm{c} ; 1 \mathrm{lb} . \$ 2.75$, postpaid. est paper wed, skin of purest paper white, flesh very cris p fine grained and snowy white in color, exDutch Sets.

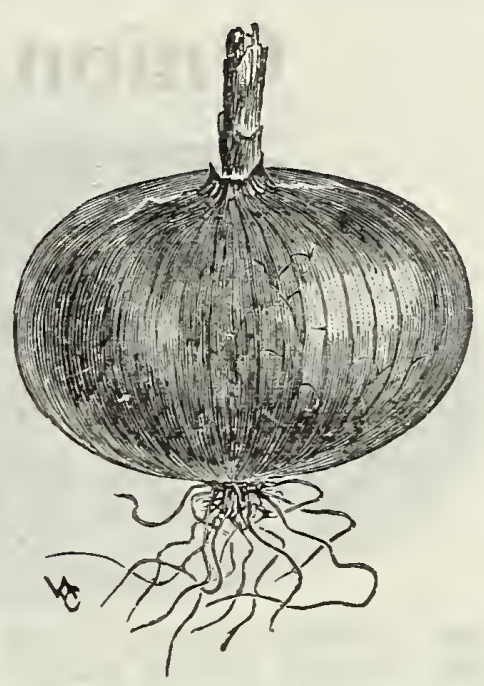

Prizetaker 360

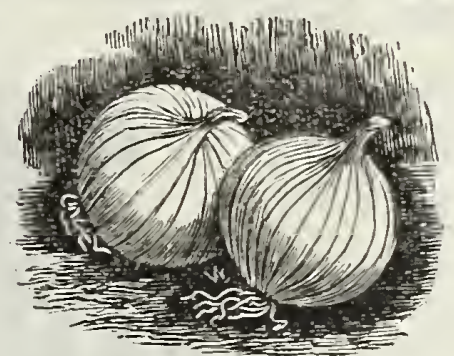

Southport White Globe 3S1

Our strain of this variety

265 Strassburg-Pkt. 5c; oz. 20c; 1/4 lb. 45c; 1 b. $\$ 1.50$, postpaid. The most popular variety for growing Yellow Dutch Onion Sets. The sets from this variety are uniformly round, plump, and a bright yellow color. Full grown onions are bright yellow,

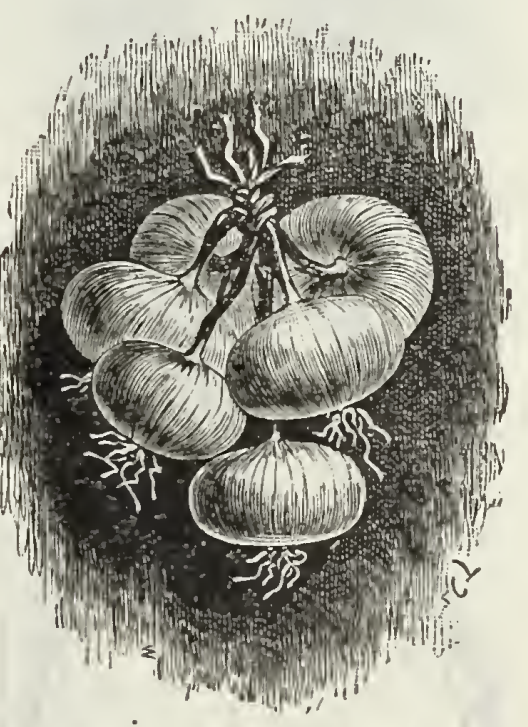

White Barletta 382

most adaptable. If sown thickly will form small white bulbs suitable for pickling, or if thinned out will produce large shaped bulbs of excellent keeping quality. - It is also used for the production of White 


\section{Onion Sets}

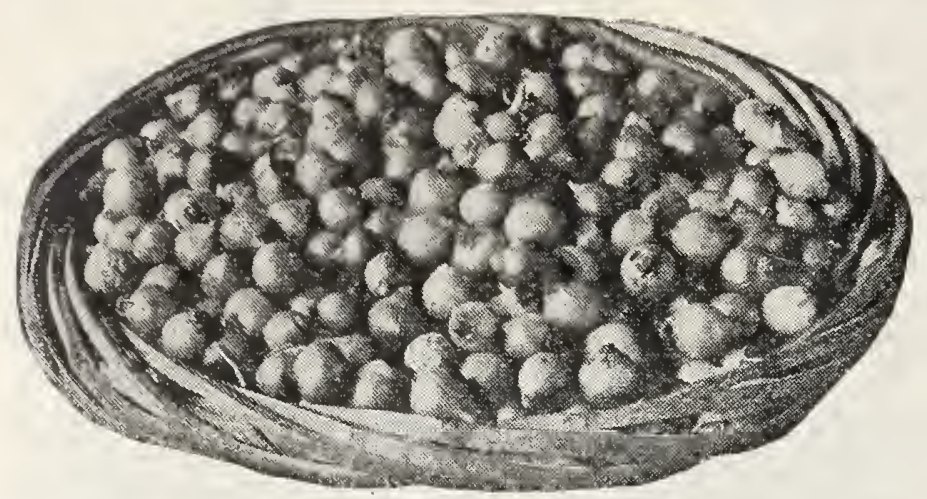

Onion Sets-The small onion sets for the production of onions are very popular in the Northwest, as they can be used or sold earlier as a rule, which is an important feature. In buying Sets, care should be exercised to see that they are in good planting condition. In the very nature of things the production of Sets is an interference with nature and the natural growth of the onion, and in consequence they require special care and attention to ensure that they will be kept in good condition, ready to grow and mature quickly when planted. Sets sold throughout the country in very many instances are given no attention whatever, and in consequence cannot be expected to produce the maximum crop.

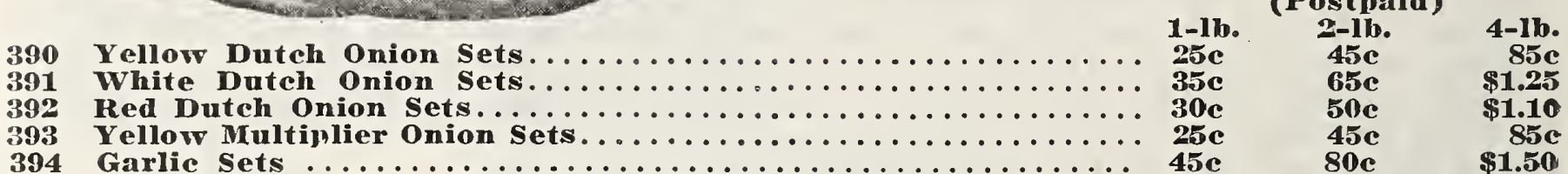

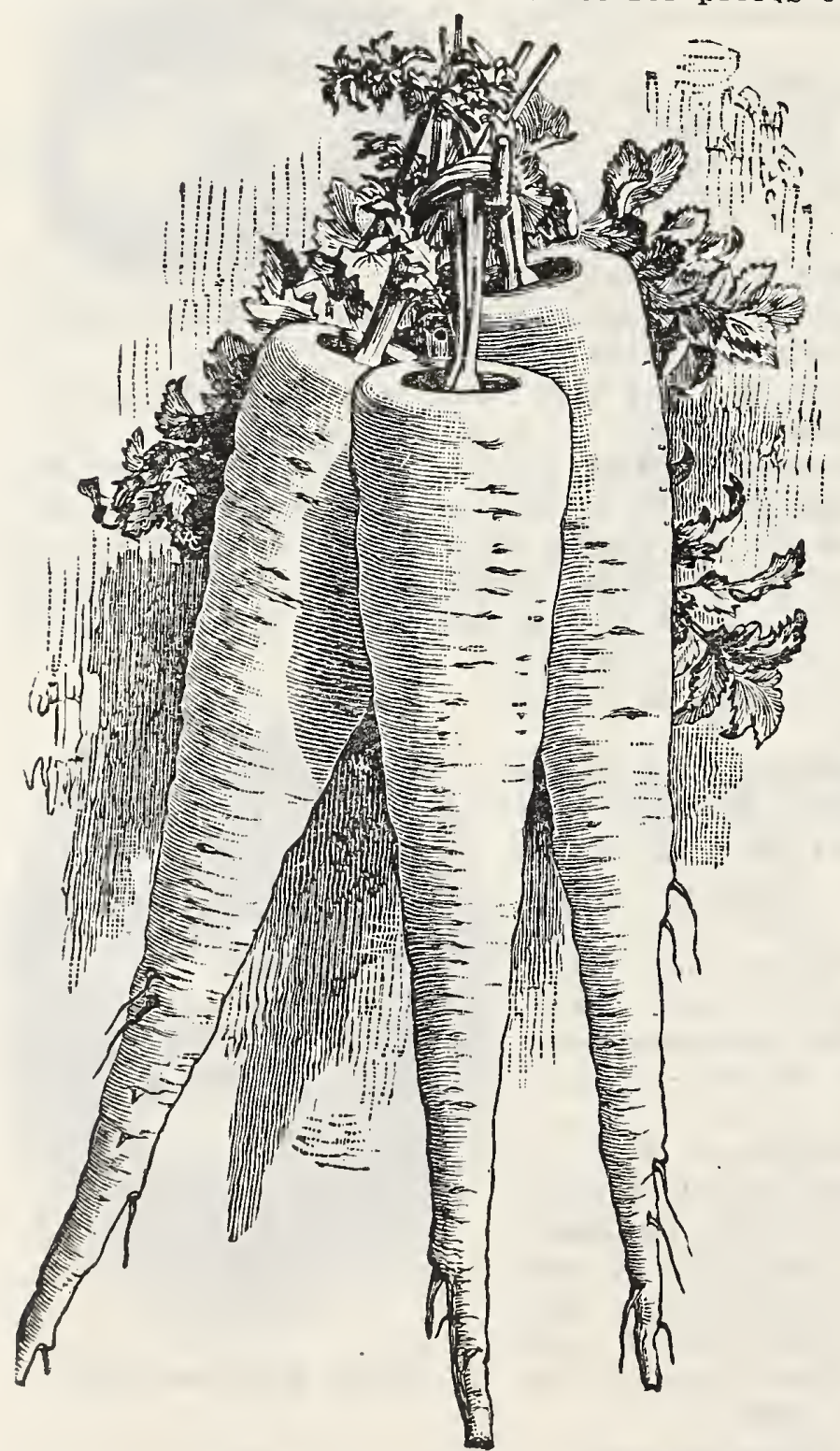

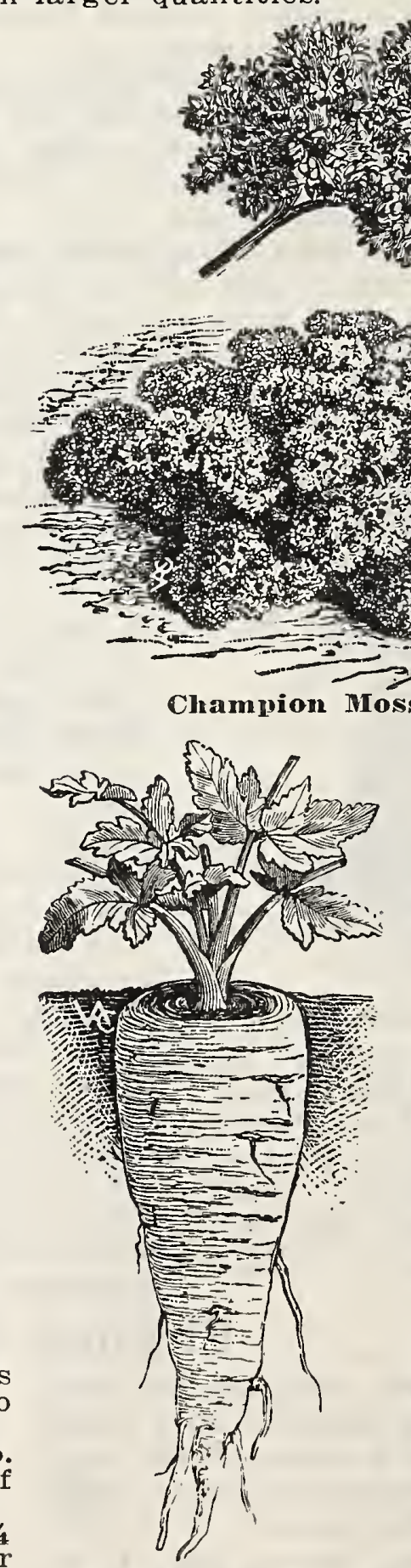

Large Gucrnsey 411

\section{Parsley}

Very $u$ seful for flavoring soups and for garnishing.

400 Champion Moss Curled-Pkt. 5c; oz. 10c; $1 / 4$ 1b. 20c, postpaid. A c o m p a $\mathrm{ct}$ growing, d e n s e ly curled variety of a dark green color very popular for garnishing.

$401 \mathrm{H} \mathrm{a} \mathrm{m} \mathrm{b} \mathrm{urg}$ or Turnip Rooted-Pk* 5c; oz. 15c; $1 / 4$ 1b. 35c, postpaid. The edible roots of this variety $\mathrm{resemb} 1$ e a small, thick parsnip, both in shape and color: much used for flavoring soups and stews. 


\section{Peas}

Peas are an ever increasing and more important crop. Our stocks have been selected with the greatest care. The varieties are such as will succeed well, and the quality is of the very best. By a judicious use of Early, Second Early and Main Crop Varieties, a succession throughout the whole season can be maintained.

\section{EARLY VARIETIES}

420 Gradus Improved-Pkt, 10c; 1/2 1b. 20c; 1b. 35c; 5 lbs. \$1.50, postpaid. By express, 10 lbs. or more, at 20c per 1b. Quite as early as the old type of Gradus or Prosperity, but a much heavier and more certain cropper. Growers who have grown the old type will remember its unfortunate habit of throwing small pods. This has been entirely eliminated from the new type. Height 3 feet.

421 American Wonder-Pkt. 10c; $1 / 2$ 1b. 20c; lb. 32c; 5 lbs. \$1.40, postpaid. By express, 10 lbs. or more, at 20e per 1b. Probably the most popular early Pea on this continent. The foliage is a dark color, while the pods, which are borne in great profusion, are lighter in color, small size, square ended; heavy cropper; height 1 foot.

422 Little Gem-Pkt. 10c; 1/2 1b. 20c; lb. 32e; 5 lbs. \$1.40, postpaid. IBy express, 10 lbs. or more, at 20c per 1b. Just a trifle later and a few inches taller than the foregoing. If sown at the same time, will maintain a succession. Height $1 \frac{1}{2}$ feet.

423 Little Marvel-Pkt. 10c; $1 / 2$ lb. 20c; 1b. 35c; 5 lbs., \$1.50, postpaid. By express, 10 lbs. or more, at 21 cer lb. An extra fine dwarf, sweet flavored Pea. Foliage and pods very dark green; pods 3 inches long, nearly round, and square ended; very productive; height 14 inches.

424 Notts Excelsior-Pkt. 10c; $1 / 2$ 1b. 20c; 1b. 32e; 5 lbs. \$1.40, postpaid. By express, 10 lbs. or more, at 20c per lb. A very early dwarf growing variety, of branching habit. The pods are small, blunt ended, while the peas are of a delicious flavor. A heavy cropper. Height $1 \frac{1}{2}$ feet.

426 Richard Seddon-Pkt. 10c; 1/2 1b. 20c; 1b. 35c; 5 lbs. $\$ 1.50$, postpaid. By express, $10 \mathrm{lbs}$. or more, at $22 \mathrm{c}$ per lb. A dwarf growing, productive variety, of excellent quality. Height 15 inches.

456 Sugar Dwarf White Edible PoddedPkt., 10c; 1/2 lb., 20e; lb., 35e; 5 lbs., \$1.50, postpaid. By express, 10 lbs., or more, at "3e per 1b. Differs from other peas, in that the pods can be used similar to string beans, 2 feet high, pods light green, $2 \%$ inches long, pointed and narrow, very early.

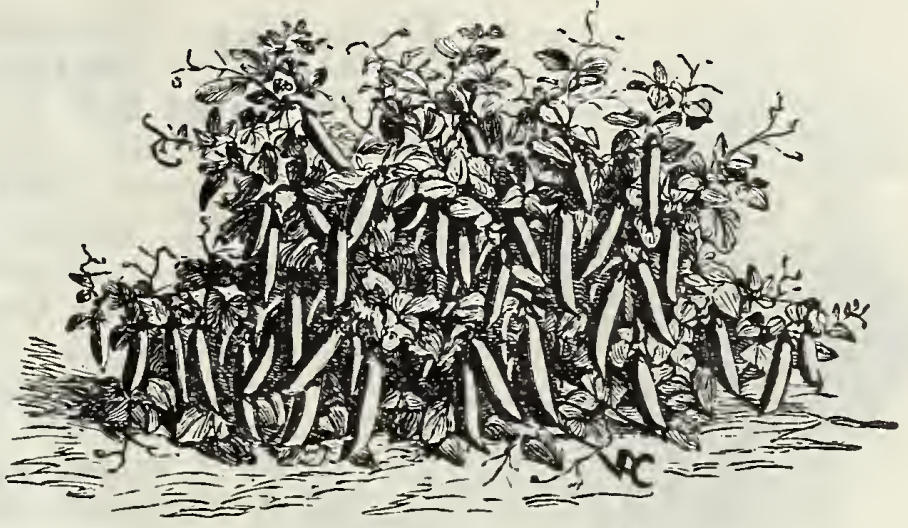

Little Marvel 423

SECOND EARLY VARIETIES

440 Daisy-Pkt. 10c; 1/2 1b. 20e; 1b. 32e; 5 los. \$1.40, postpaid. By express, $10 \mathrm{lbs}$. or more, at 20c per lb. May be best described as an early Stratagem; fairly productive and of excellent quality. Height 2 feet.

442 Thomas Laxton-Pkt. 10c; $1 / 2$ 1b. 20c; 1b. 36e; 5 lh. $\$ 1.50$ postpaid. By express, 10 lbs. or nore, at $24 c$ per lb. An excellent Second Early, coming into use almost immediately after "Gradus" and much more productive than this excellent variety. Height $2 \frac{1}{2}$ feet. Haulms moderately stout. medium green in color; pods usually between 3 and 4 inches long; straight; nearly round and square ended; the peas are a beautiful dark green color, of excellent quality.

\section{MAIN CROP VARIETIES}

440 Duke of Albany-Pkt., 10c; $1 / 2$ lb., 30c; lb., 34c; 5 lbs., \$1.50, postpaid. By express, 10 lbs., or more, at azc per lb. The earliest Main Crop Variety, coming into use immediately following the last of the Second Earlies; vigorous growing and unusually productive; pods beautiful dark green, nearly 5 inches long, broad and pointed; excellent for exhibition and a splendid market sort.

450 Rentpayer-Pkt., 10c; 1/2 1b., 20c; 1b., 36e; 5 los., sil.50, postpaid. By cxpress, 10 lbs., or more, at "4c per 1b. This is undoubtedly one of the finest peas in cultivation; quality is beyond compare, and an excellent cropper; height $2 \frac{1}{2}$ feet.

451 Iniproved Stratagen-Pkt., 10c; 1/2 1b., 20c; 1b., 35e; 5 lbs., \$1.50, postprid. By express, 10 los., or niore, at 23 per 11.. One of the best known Main Crops, and the most popular. Vines stout, of a dark green color; pods usually $4 \frac{1}{2}$ inches long; slightly curved; pointed and dark green.

452 Telephone-Pkt., 10c; 1/2 1b., 20c; 1b., 35c: 5 los., \$1.50, postpaid. By express, 10 lbs., or nore, at $23 e$ per $1 b$. An old favorite, popular in Great Britain for many years; grows to a height of 4 feet and produces a great wealth of podded peas which are borne on strong haulms. To obtain the maximum results, they should be rodded or brushed with rods not less than from 5 to 6 feet high. If this is carefully attended to, the plants will bear excellent pods for quite a long period. The pods average $4 \frac{1}{2}$ inches long, are straight, broad and pointed. usually containing 8 large light green peas of delicious flavor. 


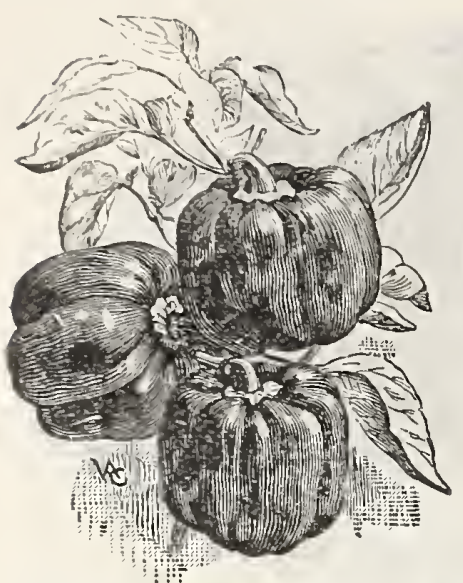

Pepper Bull Nose 465 Pepper splendid for seasoning and for making chow chow

465 Large Bell or Bull Nose-Pkt. óc; oz. 3อc; 14 1b. $\$ 1.25$; lb. $\$ 4.00$, postpaid. This first early variety is very popular in the Northwest, being well adapted for pickling purposes; the scarlet fruits are 2 inches in diameter, 3 inches long, blunt at the end, while the flavor is mild and sweet.

466 Long Red Cayenne-Pkt. 5c; 0z. 35c; $1 / 4$ Ib. $\$ 1.00 ; 1 \mathrm{~b}$. $\$ 3.50$, postpaid. A very popular variety; the fruits average 4 inches long and $3 / 1$ inches in diameter; they usually grow in a peculiar curved and twisted manner; are a bright red color. The name is rather apt as they are unusually hot and pungent.

467 Neapolitan-Pkt. 5c; oz. 35c; $1 / 4$ Ib. $\$ 1.25$; lb. $\$ 4.50$, postpaid. The earliest and most productive large variety and one of the sweetest. Fruit bright red; 4 inches long and 2 inches thick.

468 Red Cherry-Pkt. 5c; oz. 35c; 1/4 1b. $\$ 1.25 ; 1 b . \$ 4.50$, post-

paid. Fruits small, round or cherry-shaped; rich scarlet and very hot.

Peanuts Contrary to the opinion expressed by many, Peanuts can be successfully grown in the Northern States. The main thing is to sow seed of a hardy type which has been northern grown, and consequently acclimatized.

460 Early Sweet-Pkt. 10c; Ib. 35c, postpaid. We believe this to be without exception the best variety to sow in the Northern States; it stands both heat and drought admirably and is the earliest variety to ripen. The nuts are deliciously sweet. Can be grown in any light, sandy soil where potatoes succeed well.

Instead of giving cultural directions in this Catalog we have printed a special Leaflet, containing much useful information, which accompanies every order for seeds. In addition we gladly mail any of the Free Booklets to customers.

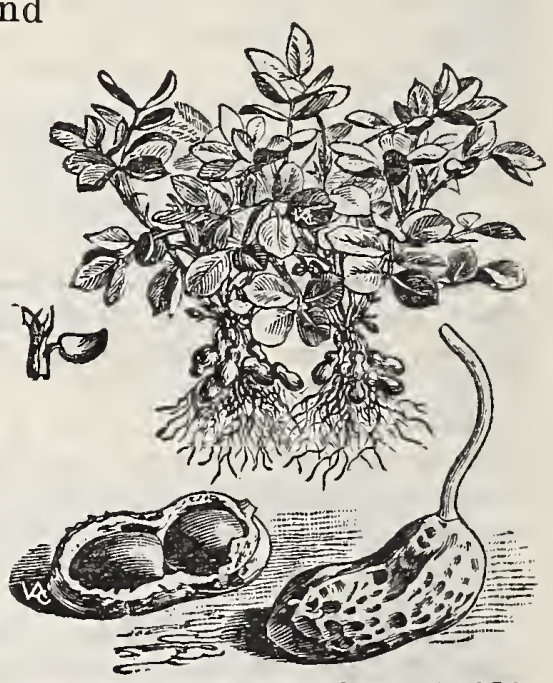

Peanut Farly Sweet 460

\section{Pumpkin}

Always in demand for pies; easily grown. Our stocks of pumpkin, like everything else, are especially selected for the Northwest.

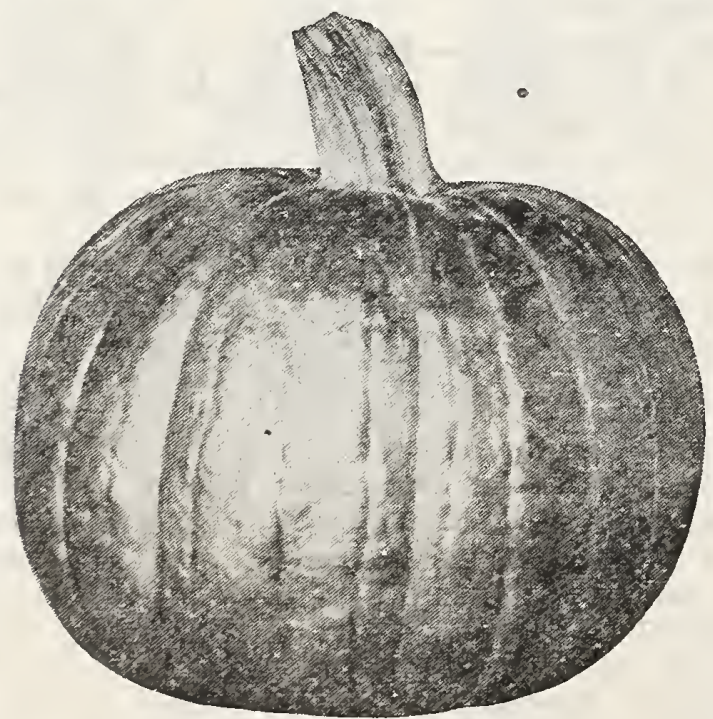

Early Sugar Pumpkin 480

480 Early Sugar-Pkt. 5c; 0z. 10c; 1/4 lb. 30c; Ib. 90c, postpaid. Fruits small, round, flattened at the ends and slightly ribbed; skin and flesh deep orange yellow; flesh very thick and of good quality.

481. Japanese Pie-Pkt. 5c; 0z. 20c; 1/4 lb. $60 \mathrm{c} ; 1 \mathrm{lb}$. $\$ 1.50$, postpaid. Grows to a large size; skin deep green with dark stripes; flesh deep yellow and of high quality; the seeds are sculptured like Chinese letters.

482 King of the Mammoths-Pkt. óc; oz. 10c; $1 / 4$ llb. 40c; lb. $\$ 1.40$, postpaid. This well known variety is without doubt the giant among pumpkins; specimens having been grown weighing as high as 250 pounds and measuring 2 feet or even more in diameter; the fruits are round and flattened, slightly ribbed, while the skin is a salmon-orange; the flesh being bright yellow and very thick. Useful alike for pies or stock feeding. An excellent keeper.

483 Large Cheese or Kentucky FieldPkt. 5c; 0z. 10c; 14 1b. 25c; 1b. 70c, postpaid. Large, round, flattened fruits, much ribbed and creamy buff in color; flesh yellow and very deep; of fine quality and one of the best canning sorts.

484 Connecticut Field-Plit. 5c; oz. 10c; 1/4 1b. 20c; lb. 65c, postpaid. The most popular variety for planting in corn for stock feeding and also for making pies, fruit oblong flattened at the ends, smooth hard, reddish orange skin, with orange yellow flesh.

All Vegetable and Flower Seeds prepaid unless otherwise stated 
Radish $\begin{aligned} & \text { Welcome at every meal, and being } \\ & \text { so easily grown, there is no excuse }\end{aligned}$ for their absence.

TURNIP OR ROUND SHAPED VARIETIES.

491 Rosy Gem-Pkt. 5c; oz. 10; 1/4 lb. 25c; lb. 75c, postpaid. Deep scarlet on the top, blending into white at the bottom. A very fine sort either for forcing or open ground culture.

492 Scarlet Globe-Pkt. 5c; oz. 10c; 1/4 1b. 25c; 1b. 90c, postpaid. A bright red variety, with firm, crisp, tender flesh; grows to a large size without becoming pithy.

493 Scarlet Turnip White Tipped-Plat. 5c; oz. 10c; 1/4 lb. 25c; 1b. 65c, postpaid. Extra early forcing variety, valuable also for ordinary outdoor use.

494 Non Plus Ultra-Pkt. 5c; oz. 10c; 14́ lb. 30c; lb. $\$ 1.00$, postpaid. Very early, bright scarlet, with short top; useful for forcing; crisp and tender.

495 White Globe-Pkt. 5c; oz. 10c; 1/4 lb. 30c; 1b. \$1.00, postpaid. A beautiful white skinned variety; tender and crisp.

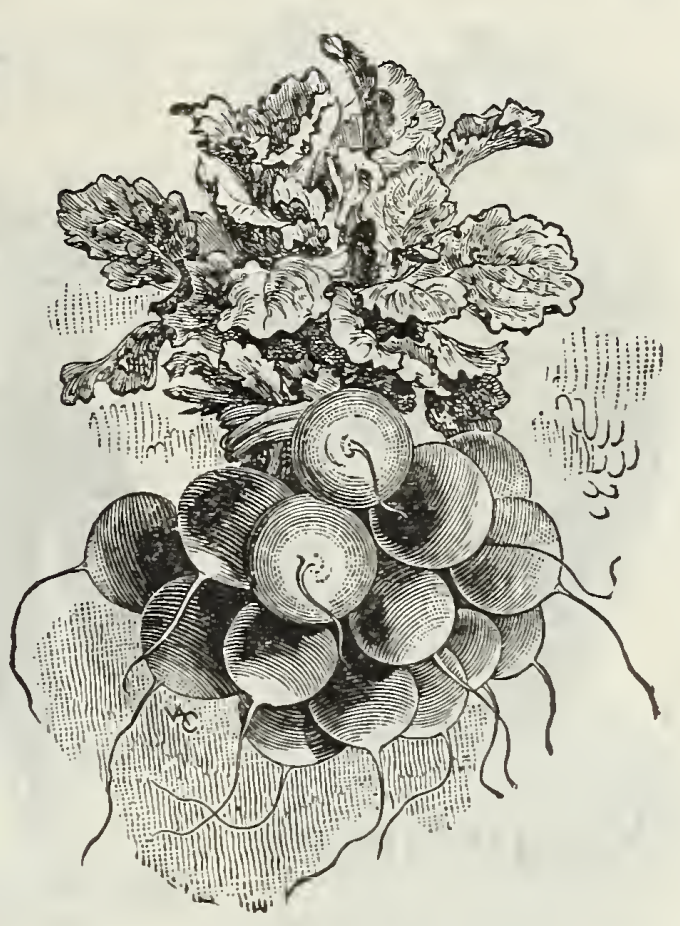

496 Turnip Varieties-Pkt. 5c; oz. 10c; 14 1b. 25c; lb. 65c, postpaid. For home use, sowing in mixture is very desirable, and recommended, as it enables one to have a varied selection at small cost and in a small space.

\section{OLIVE, OR OVAL SHAPED}

497 French Breakfast-Pkt. 5c; 0z. 10c; 1/4 1b. 25c; 1b. 7oc, postpaid. The most popular variety of radish; oblong in form, small and quick growing; color bright rose scarlet, with small white tip.

498 Early Scarlet Olive Shaped-Pkt. 5c; oz. 10c; 14 ll). 30c; 1b. $\$ 1.00$, postpaid. Very early, bright scarlet; flesh white and crisp.

499 Early White Olive-Shaped-Pkt. 5c; oz. 10c; 1/4 lb. 30c; Ib. \$1.00, postpaid. Handsome, small, white, quick growing variety; mild, crisp and tender.

\section{LONG SHAPED VARIETIES.}

500 Chartier-Pkt. 5c; oz. 10c; 1, 1b. 25c; 1b. 65c, postpaid. A very handsome variety; roots 7 to 8 inches long, and rather thick; deep scarlet at the top, shading off to pure white at the tip.

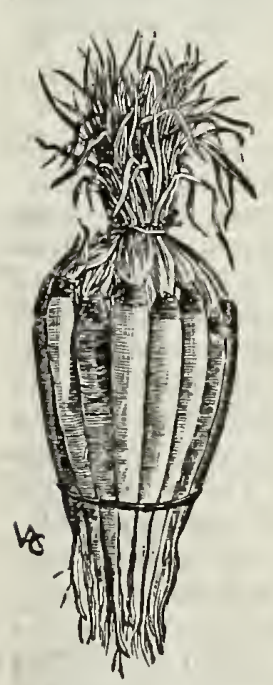

Salsify 525

501 Icicle-Pkt. 5c; oz. 10c; 14 1b. 25c; 1b. 70c, postpaid. The leading long white radish and one of the earliest; beautiful quality, and remains fit for use a long time.

504 Long Brightest Scarlet-Pkt. 5c; oz. 10c; 14 lb. 25c; lb. 75c, postpaid. One of the best and earliest of the long scarlet radishes, crisp and tender until full grown.

503 Mixture-Pkt. 5c; oz. 10c; 1/4 lb. 25c; 1b. 60c, postpaid. A mixture of all summer varieties for home use; the selection is $\mathrm{A}-1$.

\section{SALSIFY, OR VEGETABLE OYSTER}

525 Mammoth Sandwich Island-Pkt. 5c; 0z. 15c; 1/4 lb. 45c; lb. $\$ 1.50$, postpaid. Cultivated for the sake of its yellowish white roots which are stored for use as a winter vegetable. The leaves of this new variety may be used as a salad.

\section{RHUBARB OR PIE PLANT}

521 Victoria-Pkt. 5c; 0z. 10c; 14́1 1b. 25c; lb. 80c, postpaid. Well known standard variety. Good for general use.

For remainder of Radish see next page.

Our Radishes will surely please you. 


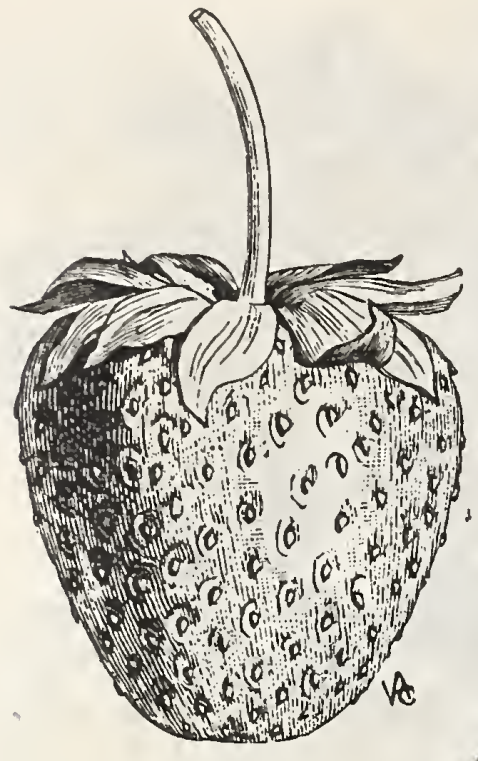

\section{Strawberry}

The raising of Strawberry Plants from seed is very simple; they are easily grown. Sow the seed thinly, in a small box or seed pan, cover very slightly and press down firmly. Water by dipping in a bucket or other vessel so as not to disturb the seed. Thin out as soon as young plants are fit to handle.

570 Large Fr it ed Perpetual Saint Fiacre -Pkt., 10c, postpaid. Fruit oblong or heartshaped, large size; of a good red color; flesh salmon pink; very juicy, slightly acid, of excellent flavor.

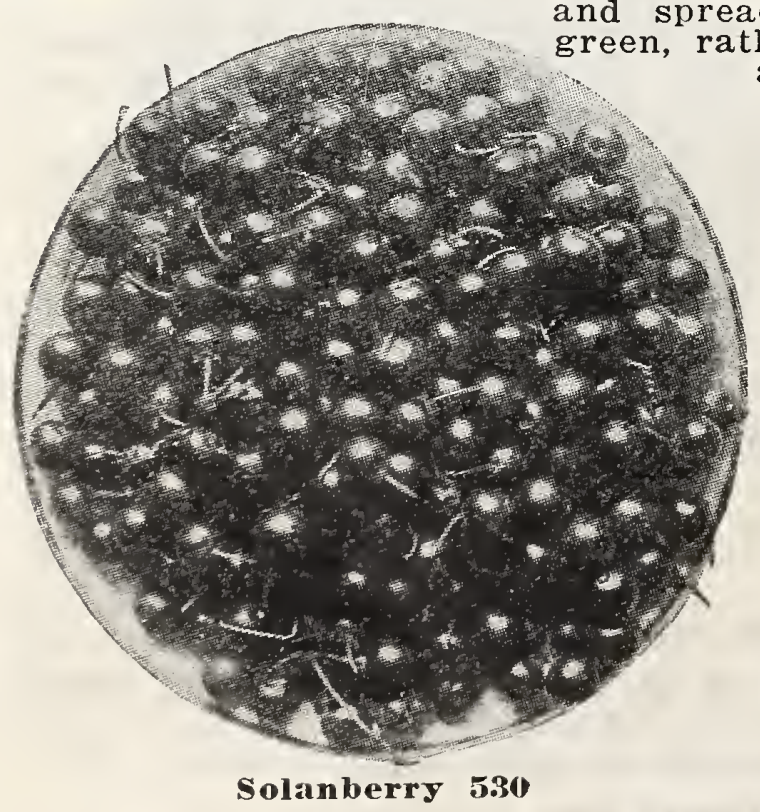

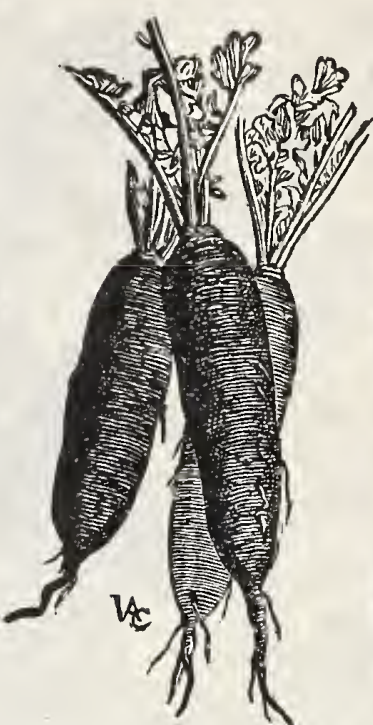

Long Black

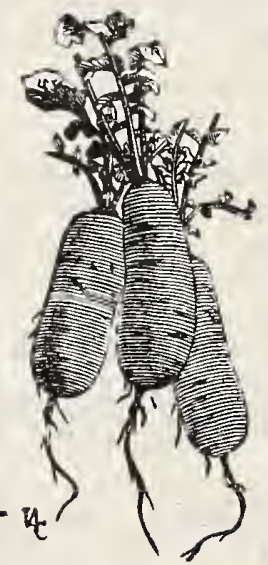

China Rose 512
FALL OR WINTER VARIETIES This type of radish is not grown as extensively as it ought to be, considering its excellence. The foreign born non-English speaking settlers seem to have appreciated its usefulness. Sown in June or July, they will grow 6 inches long and 2 inches in diameter, and will keep all winter if stored in sand in a cool celar free from frost. Try them.

510 Black Spanish, Round-Pkt. 5e; oz. 10c; $1 / 4$ 1b. 25e; 1b. 90c, postpaid. Roots round, 3 to 4 inches in diameter; skin almost black; flesh white, crisp and pungent.

511 Black Spanish, Long ShapedPkt., 5c; oz., 10c; $1 / 4$ 1b., 25e; 1b., 90c, postpaid. One of the latest and hardiest varieties for winter use, roots 8 to 9 inches long, to 3 inches in diameter, and nearly black in color.

512 China Rose (Scarlet China) Pkt., 5e; oz., 10e; $1 / 4$ lb., 25e; 1 b. Doc, postpaid. One of the best winter sorts; skin smooth, and bright deep rose color; flesh white, crisp and pungent; the roots grow 4 to 5 inches long and 2 inches thick.

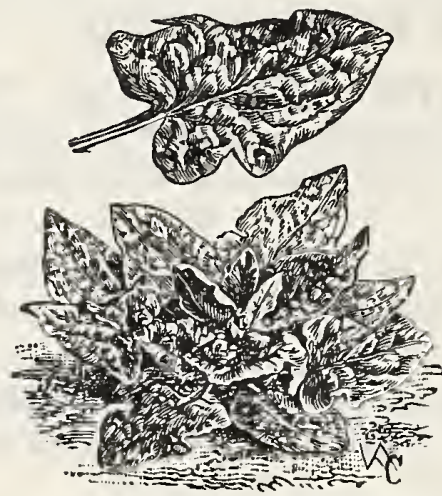

Spinach Very easily grown, and ply of tasty, healthful greens throughout the season.

585 Bloomsdale or Savoy-Pkt., 5c; oz. 10c; 1/4 1b., 20c; lb., 60c, postpaid. Very early and haray and one of the best for market and canning; plant of upright growth; Petiole (Stem) 3 inches long: leaves medium size; color glossy green

536 Long Standing, Round SeededSpinach, Long Stand- Pkt., 5c; oz., 10c; $1 / 4$ 1b., 20e; 1b., 60c, posting $\mathbf{5 3 6}$ paid. Slower growing than Bloomsdale. but stands much longer before running to seed; leaves very large and of good substance. 540 New Zealand-Pkt., 5e; oz., 10c; 1/4 lb., 30c; lb., 90c,
postpaid. Entirely distirct from the true Spinach; plant tall ding, with numerous side shoots; leaves mediun and under adverse conditions.

For Spinach Beet or Swiss Chard, see page 18.

\section{Solanberry Pkt., 10c. This, as} belongs to the Solanum family, and is closely allied to the Tomato, being sometimes described as the Black Currant Tomato. We recommend it very highly, have been watching it for several years, and believe it to be one of the best acquisitions of its kind for the Northwest. It is perfectly hardy, will stand frost that puts Beans, Corn, Tomatoes, etc., entirely out of business. Ripe fruits can be gathered from August 15 th till late in October. Easily grown; the main thing is to give them plenty of room, one plant will occupy a space of 3 to 4 feet square. Can either be sown in pots or boxes like Tomatoes and then transplanted to the open or sown in the open ground whenever it is fit, and thinned out. Useful for pies, pickles, sauces etc., either alone, or mixed with other fruits.

We specialize in hardy, early varieties 
Squash The Squash is one of the most nutritious and varieties come to the table early in the season, while the fall and winter varieties from August till spring.

558 Delicious-Pkt., 5c; oz., 20c; $1 / 4$ lb., 50c; $1 b$. , $\$ 1.40$, postpaid. A winter variety of medium size, pear-shaped, of a dark green color, flesh orange, very dry and fine flavor.

550 Extra Early Orange Marrow-Pkt., 5c; oz., 20c; $1 / 41 \mathrm{lb.}$ 50c; lib., \$1.50, postpaid. The earliest of the Marrow Squashes and of fair size; color orange red; very prolific; a good keeper, and of highest quality.

551 Giant Summer Crookneck-Pkt., 5c; oz., 10c; $1 / 4$ 1b., 35c; lb., \$1.20, postpaid. The largest and one of the earliest summer varieties; fruits often 2 feet long; very warty; and deep orange in color.

552 Golden Hubhard-Pkt., 5c; oz., 10c; 1/4 1b., 35c; 1b., \$1.25, postpaid. Quite like the old Hubbard in form and haibit, but decidedly earlier; the shell is moderately warted, hard, strong and of rich orange red color; flesh deep orange, dry and of best quality.

553 Improved Hubbard-Pkt., 5c; oz., 10c; 1/2 1b., 35c; 1b., \$1.25, postpaid. The standard Winter Squash; fruits large, heavy and moderately warted; shell dark bronze green; flesh bright orange yellow; fine grained, thick and dry.

554 Warted Hubbard-Pkt., 5c: oz., 10c; $1 / 4$ 1b., 35c; $1 b$, \$1.25, postpaid. This variety of the Hubbard is a great favorite with the market men. It is very striking in appearance, the warty knobs draw general attention. Grows to nearly double the size of the common Hubbard.

555 Early White Bush Scallop-Pkt., 5c; oz., 10c; 1/4 1b.,

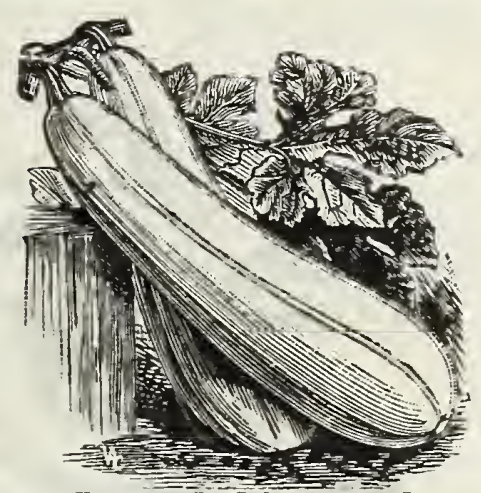

Long White Bush Marrow 556

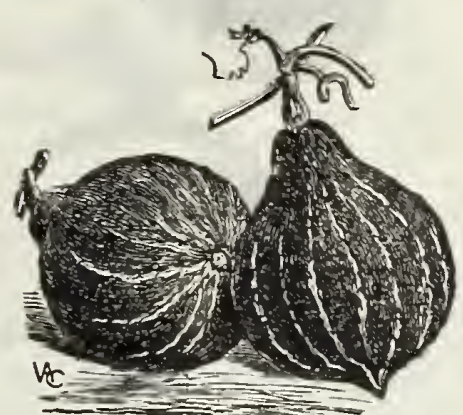

Improved Hubbard 553 35c; lb., \$1.20, postpaid. Very early summer; fruit flattened and scalloped, comparatively smooth on the surface and creamy white color.

559 Mammoth Whale-Pkt., 5c; oz., 20e; 3/4 1b., 35c; 1b., \$1.25, postpaid. Fruit 2 to 3 feet long, thick in the middle and narrowed at the stem end, sometimes weighing 75 pounds; skin gray green; flesh orange yellow, of excellent quality.

556 Vegetable Marrow, Long White Bush-Pkt., 5c; ox., 25c; 1/4 1b., 60c; 1b., \$2.00, postpaid. The well known Long White English Vegetable Marrow; the fruits are smaller than the trailing variety, but the plants take up much less space and can be planted closer.

557 Vegetable Marrow, Long White Trailing-Pkt., 5c; oz., 25c; 1/4 1b., 60c; 1b., \$2.00, postpaid. Fruits larger and a more abundant cropper.

TOMATO

A most popular and wholesome vegetable; can be easily grown if attention is paid to cultural instructions, supplied free with every order.

581 Bonnie Best-Pkt., 5c; oz., 25c; $1 / 4$ lb. 00c; 1 b., \$3.00, postpaid. A very early variety; fruits medium size; good market sort; free from liard core.

582 Crimson Cushion-Pkt., 5c; oz., 25e: $1 / 4$ lb., 90c; lb., \$3.00, postpaid. The largest of the bright red colored tomatoes; heavy cropper, of excellent quality.

583 Disco Earliana-Pkt., 5c; oz., 30c; $1 / 4$ lb., \$1.00; lb., \$3.00, postpaid. Our strain of this excellent variety is second to none and is, we believe, the earliest and best tomato in cultivation; unusually productive for an

\section{SMALL FRUITED VARIE'TIES}

590 Pear Shaped Red-Pkt., 10c; oz., 40e; postpaid. Useful for preserves. Fruits distinctly pear-shaped, beautiful bright red color.

591 Pear Shaped Yellow-Pkt., 10c; oz., 40c, postpaid. Similar to the Red Variety, with exception color.

592 Red Cherry-lkt., 10c; oz., 45c, postpaid. Fruits very small, about the size of a large cherry; smooth and round; for preserves.

593 Strawberry (Ground Cherry or Husk)Pkt., 5c; oz., 35e, postpaid. The true Golden Husk Tomato; esteemed for preserves.

s94 Yellow Plum-Pkt., 10c; oz., 40c, postpaid. A small yellow fruited variety, resembling a plum in size and form. early sort; the fruits are of a medium size, round; very smooth and solid; the color is a bright scarlet; the flesh is of excellent quality and has, by careful selection, been developed so as to be as free as possible from seeds.

584 Golden Queen-Pkt., 5c; oz., 30c; 1/4 1b., 80c, postpaid. Beautiful golden yellow color; ripens early; produces a large, smooth. solid fruit; very attractive and admirable for mixing with the Red variety for salads.

585 John Baer-Pkt., 5c: oz., 25c; 1/4 1b., 00c; 1b., $\$ 3.00$, postpaid. Our stock of this excellent variety is of very uniform type; early, productive and of excellent quality. Splendid variety for shipping.

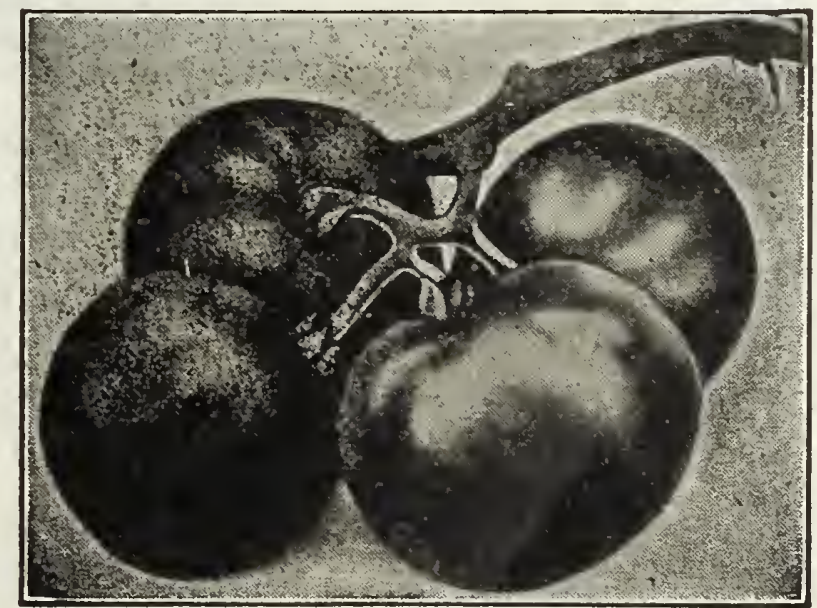

Disco Earliana 583

Disco Earliana is a wonderful cropper 


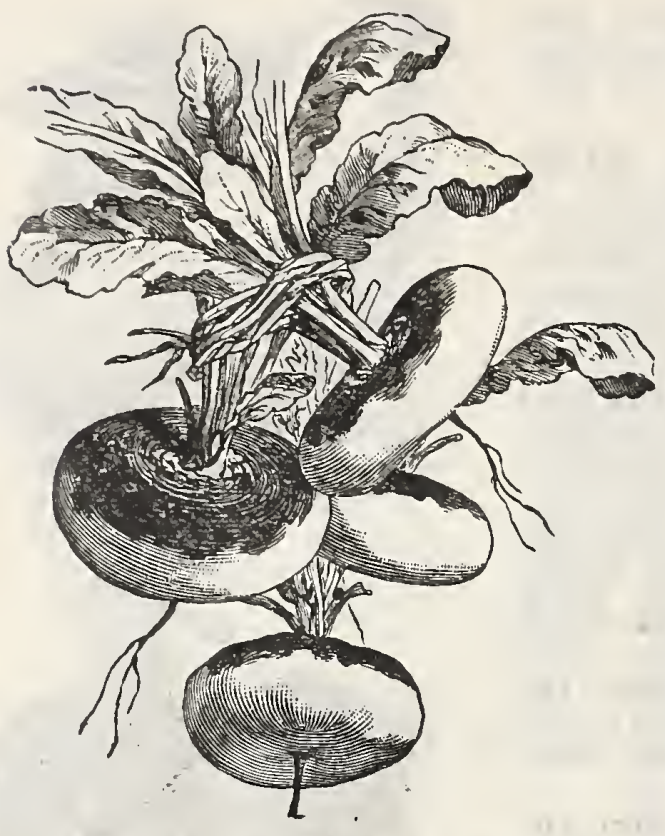

Purple Top Strap Leaved 611
Turnip If grown quickly and used as soon as small garden turnips are a they become stringy, the late use, DISCO Garden Surede is

610 Purple Top Strap Leaved-Pkt., 5e; oz., 10c; 1/4 Ib., 20c; lb., 60e, postpaid. A very early productive variety. Roots are flat shaped, medium size, purple or dark red above ground, white below; flesh is white, exceedingly tender and fine grained. The most widely cultivated and best known variety on the American continent.

G11 Puple Top White Globe-Pkt., 5e; ox., 10e; 1/4 Ib., 20e; lb., 60e, postpaid. Very similar to the above in every particular excepting in shape, being a perfect globe shape, whereas the other variety is somewhat flat. A very superior sort and we highly recommeñ̄ it.

\section{Swede or Rutabaga}

614 DISCo Special Garden or Table Swede-Pkt., 5e; oz., 10c; $1 / 4$ lb., 25e; lb., 75c, postpaid. Recommended for garden purposes, being very compact in top, with small, clean, neat, well shaped roots, thick skin and sweet tender flesh.

\section{Herbs $\begin{gathered}\text { Pot Sweet and } \\ \text { per } \text { pht., sc. }\end{gathered}$}

630 Anise. Used as a condiment for flavor-

ing.

635 Balm. An old fashioned seasoning.

636 Basil Bush. In demand for flavoring. 637 Basil Sweet. Very aromatic for flavoring.

638 Borage. A beekeeper's plant.

639 Caraway. The seeds are used for flavoring.

640 Catnip. Grown for bee pasture; also seasoning.

641 Coriander. The seeds are used for flavoring.

\section{Tree}

Surround your house wiih trees, shrubs, and a hedge here and there, plant them judiciously, not too close, so that in time they will darken the house and be a nuisance, but close enough to afford shelter and privacy and make your place more homelike.

The most economical and in the long run the most successful method of raising trees and shrubs, whether for hedges, wind breatis or as ornamental trees around the home, is to raise them from seed, right at your own home. The list offered by us is a careful selection, easily raised, grow quickly and well adapted for the Northwest and Middle West States.

Those marked with an asterisk * are suitable for hedges and should be sown thinly either in 2 or 3 rows 9 inches apart, according to whether a narrow or wide hedge is desired, just where you want the hedge, the ground having been previously well prepared, no transplanting or thinning will be required. If clipped carefully when about 12 inches high, this will encourage branching and so ensure a close growing, nice appearing hedge: Caragana makes the best hedge.

Trees for transplanting should be sown in drills 12 inches apart and the young trees transplanted as soon as large enough to handle, lift carefully so as to disturb the roots as little as possible.
642 Dill. For flavoring pickles.

643 Fennell. For garnishing and flavoring sauces.

650 Horehound. Very useful for coughs.

651 Hyssop. Great medicinal value.

655 Lavender. Very fragrant perfume.

660 Marjoram Sweet. For seasoning.

670 Roscmary. Leaves very fragrant.

671. Rue. Used medicinally.

680 Sage. Most useful aromatic herb.

681 Savory Summer. Useful aromatic herb. 690 Thyme. Useful aromatic herb.

695 Wormwood. Good poultry medicine.

\section{Seeds}

Tree, Ornamental Shrub and Fruit Seeds

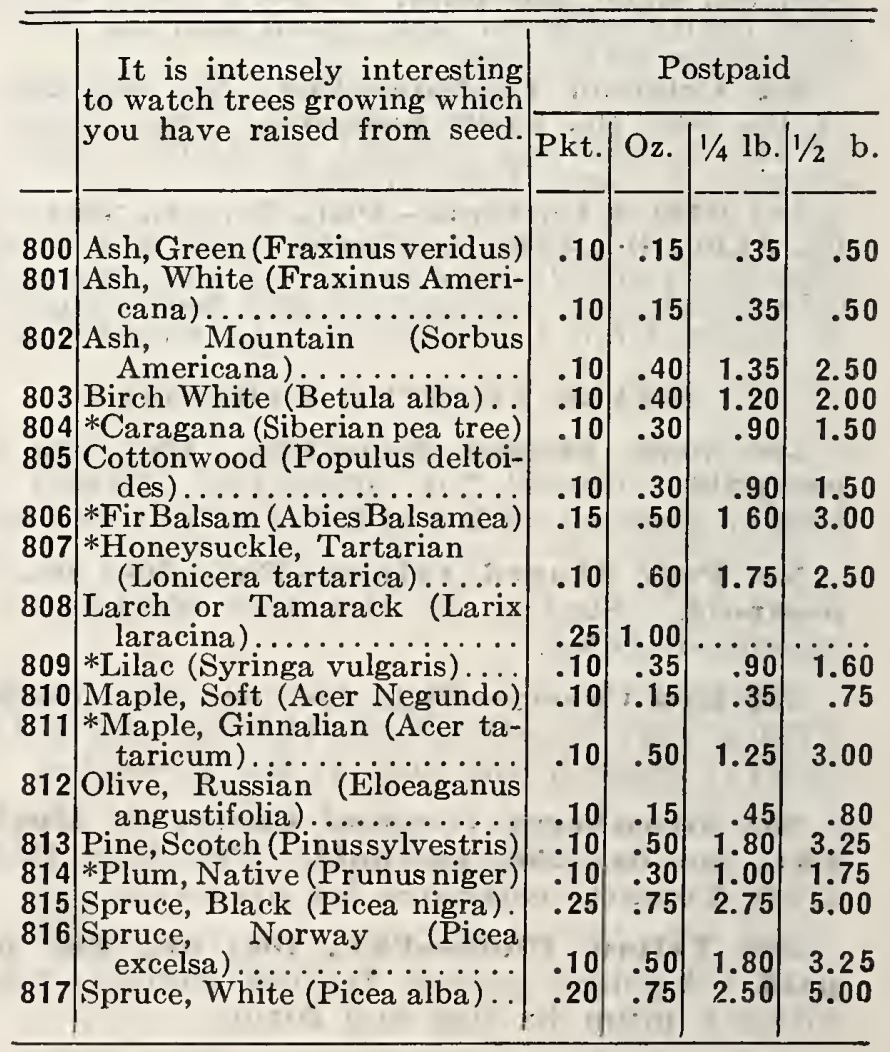




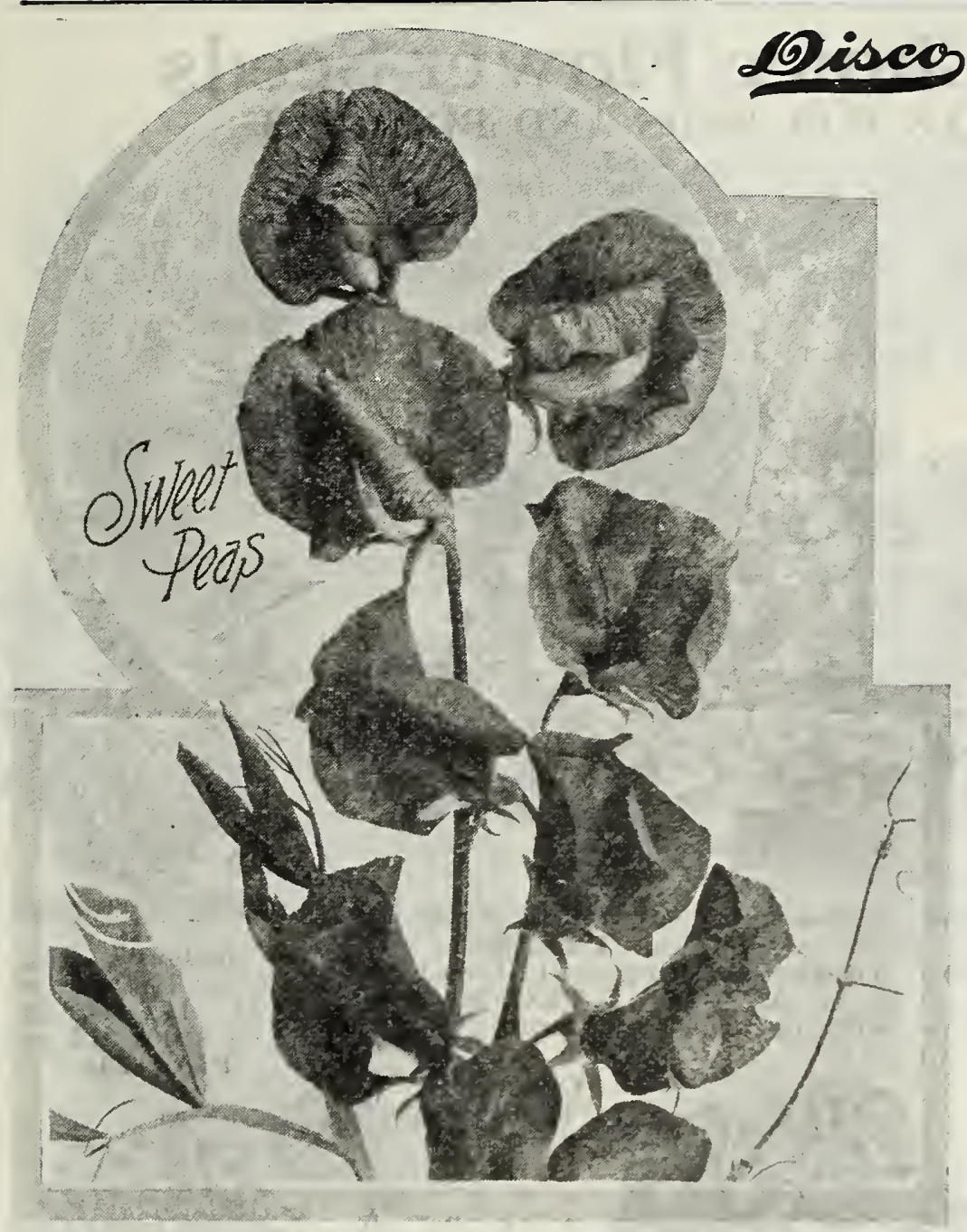

Select List, Large Packets 10c each. 2010 Barbara-Large salmon orange. 2021 Cherub-Rich cream edged rose. 2022-Constance Hinton-White, of enormous size and fine Spencer form.

2030 Dainty Spencer-Large white edged with clear rose pink.

2031 Dobbie's Cream-The best primrose self, grand color.

2032 Don Alvar-Large light lavender, pleasing color.

2040 Elfrida Pearson-Large shell pink, a leader in its class.

2051 Fiery Cross-Bright red orange cerise, very beautiful.

2060 George Herbert-Bright rosy carmine, of large size.

2070 Helen Pierce-White mottled and marbled bright blue.

2071 Hercules-Mammoth rosy pink, fine form and color.

For the convenience of our customers who desire to grow Sweet Peas for. Hospital work or for marketing or mailing to friends, we offer the following Unwin varieties which have more substance than the spencers and travel infinitely better.

2053 Frank Dolby-Pinkish mauve and lavender, fine substance. 5c pkt.

2061 Gladys Unwin-Clear bright light pink, free flowering. 5c pkt.

2132 -Norah Unwin-Pure white, splendid market variety. 5c pkt.

\section{Giant or Butterfly Spencers}

We are certainly well pleased with reports we have received from our customers who tried our Sweet Peas last year for the first time. "The best we ever had" or "as good as we got anywhere," were the remarks we heard. We are satisfied that you cannot beat our Sweet Peas, no matter what price you pay or where you get them. Disco Sweet Peas will measure up to your entire satisfaction. Large packets 10c each.

2080 Illuminator - A glorious. orange salmon, overlaid with cerise pink.

2100 King Edward-Rich crimson self, vigorous grower.

2101 King Manoel-Giant chocolate maroon'self.

2102 King White-A s $u$ pe r b white, the best for the Northwest.

2110 Lord Nelson-Dark blue.

2120 Margaret Atlee - Apricot pink on cream ground.

2121 Mrs. Cuthbertson-P i n k and white bicolor, best of its class.

2123 Mrs. Hardcastle SykesDelicate blush pink, a great favorite.

2130 New Margaret MadisonTrue lavender, a very dainty flower.

2131 New Miriam Beaver-S of t shell salmon pink on cream ground.

2140 Orchid-Lavender suffused pink.

2160 Rosabelle-Bright rose, one of the very best, fine form.

2171 Royal Purple - The very best purple variety, aptly named.

2180 Senator-Claret and chocolate stripe on light heliotrope.

2191 The President-Dazzling or a $\mathrm{ng}$ e scarlet, fine flower.

2200 Vermilion Brilliant-Fine $\mathrm{l}$ a $\mathrm{rge}$ scarlet, the best of its class.

2210 Warrior-Rich chocolate and maroon, a fine type.

2211 Wedgewood-Clear, a z u r e blue, with mauve tint.

2220 DISCO Spencer or Butterfly Mixture -Pkt. 10c; 0z. 25c; 14 1b. 75c. A beautiful blend of 75 Spencers including many new varieties. The choicest mixture to be had.

2225 DISC0 Grandiflora Mixture-Pkt. sc; 0\%. 15c; 14 1b. 50c. A splendid assortment of finest colors, blended to harmonize and insure a fair proportion of all.

New Early Flowering Long Season Spencers

We have pleasure in offering a choice selection of this new race of Spencers. 2295 Early Choice Mixed-B e a u t if u $\downarrow$ colors. 10c pkt. 


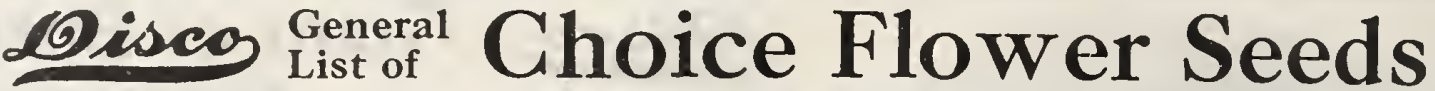 SHOWY ANNUALS FOR BEDS AND BORDERS}

Easily raised from seed.

Those marked "H. H. A." signify Half Hardy Annuals, are best sown in pots or boxes indoors and transplanted to their flowering quarters when the weather is favorable. Those marked "H. A.," Hardy Annuals, may be treated in the same manner but may also be sown right out of doors. If sown lightly and the plants thinned out after they have germinated, they will give excellent results.

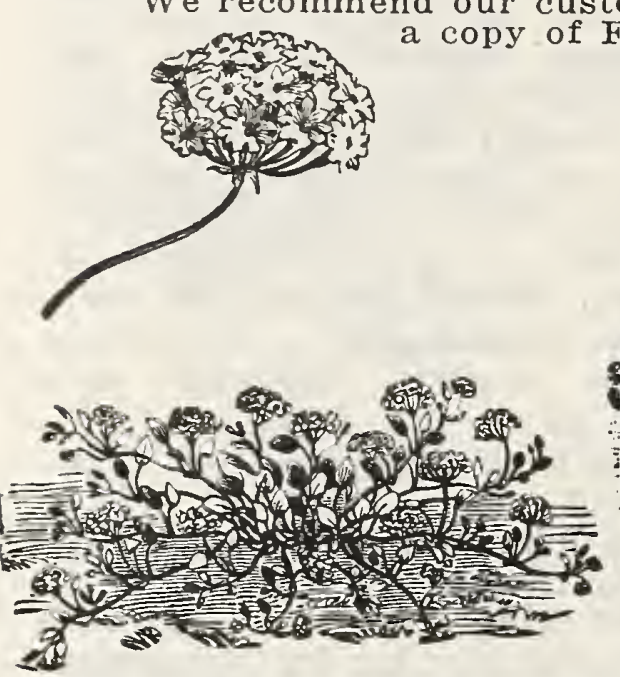

2500 A b r o ni a, umbellata, lilac fragrant, H. H. A., 3-inch. Sand verbena, grows well in

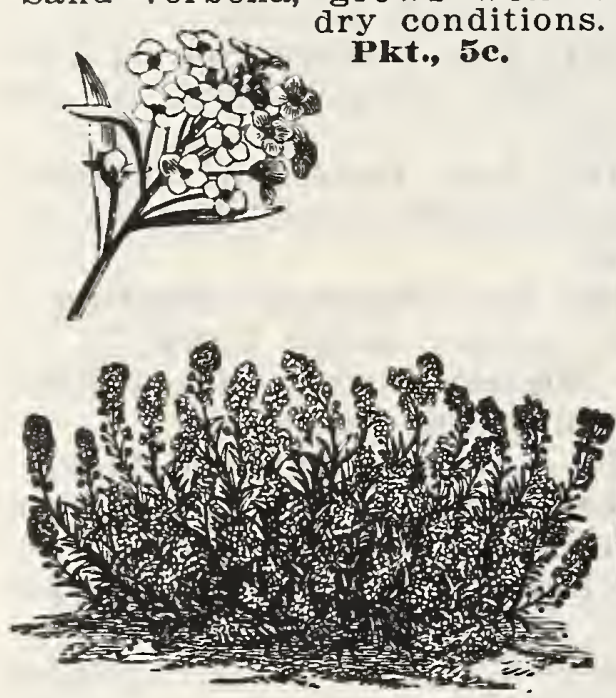

2512 Alyssum, Benthami Sweet Alyssum, H. A., 4inch. Valuable for edgings. Pkt., 5e.

2513 Alyssum, Benthami Compactum, H. A., 4-inch. Little Dorrit, very dwarf. Pkt., 10c.

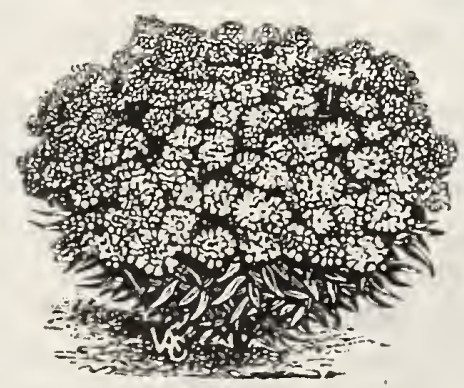

\section{Candy tuft}

H. A., 12-in. each. Pkt., 5c. One of the brightest and easiest grown hardy annuals. Gives a gorgeous display through the season. 2576 Empress White, $H$. 2578 Dunnett's Crimson. 2581 mixed, extra choice.

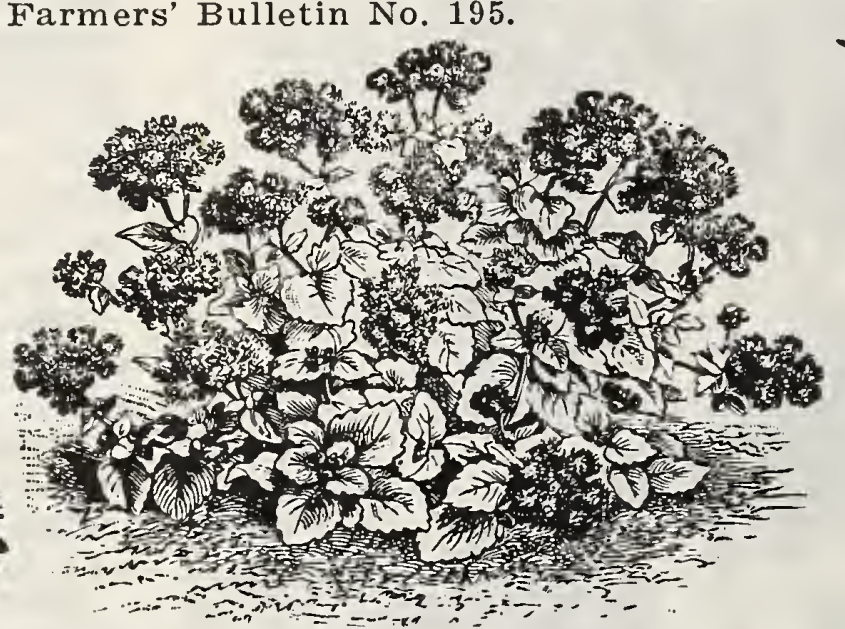

2506 Ageratum, Imperial Dwarf Blue, H. H. A., 6-inch. Pkt., 5c. 2507 Ageratum, Imperial Dwarf White, H. H. A., 6-inch. Pkt., 5c.

ered, $H$. Fine bedding plants, blooming till inch. A splendid pot
late in Fall.

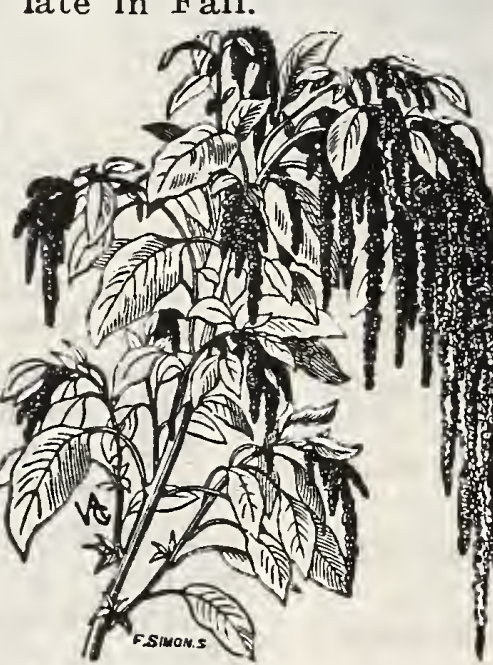

2515 Amaranthus, cau datus, H. A., 24-inch. Love-lies-bleeding red. Pkt., 5c.

\section{Calliopsis} Fas i l y g r o w n s u cceed a $n$ y wh e re : $\mathrm{s} h \circ \mathrm{w} \mathbf{y}$ i n $t h$ e fl o w e $r$ b o r d e r and pro$v$ i d e g raceful, a t t r a ctive $\mathrm{cut}$ bloom of unique colors.

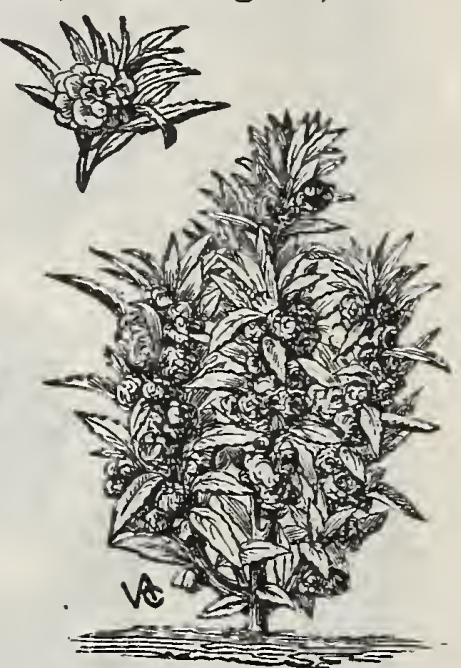

2559 Balsam, Doub le Camellia - flow plant. Pkt., 10c.

2569 tinctoria (bi-color), H. A. 24-inch. Pkt., 5c.

2571 tinctoria nana "Golden Ray," H. A., 12-inch. Pkt., 5c. 2574 Dwarf mixed, H. A., 9inch. Pkt., 5e.

2575 Drum., Golden Wave. $H$. A., 18-inch. Pkt., 5e.

\section{A STERS}

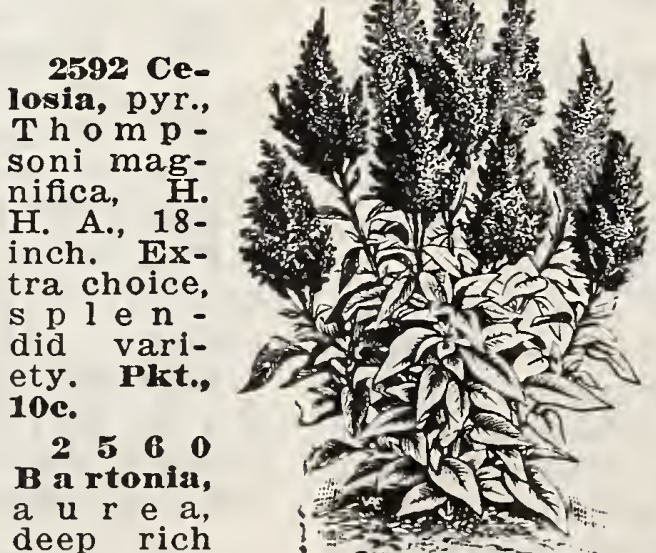

deep rich

yellow, $\mathrm{H}$.

Beautiful poppy-like. Pkt., 5c. 2565 Brachycome, iberidi-

folia, blue, H. H. A., 6-inch. Swan River Daisy, lovely. Pkt., 10e.
H. H. A. each. Pkt., 10e Our selection of Asters is the finest ever offered to the garden lovers of the Western States. Easily grown, provide abundance fut flowers.

2531, Comet, mixed, 18inch.

2534, Comet, Giant mixed, 18-inch.

2537, Dwarf Chrysanth. mixed, 9-inch.

2539, D w a f Victoria, mixed, 9-inch.

2542, Sinensis, Mauve, 18nch.

2543, Sinensis, 18-inch. Lovely single forms of the original $\mathrm{Ch}$ in ese Aster. 2565 Calendula, offcinalis $\mathrm{A}$. pl. Meteor, H. A., 12-inch. Scotch Marigold, double. Pkt., 5e. You simply must try our Asters this year. 


\section{Showy Annuals-Continued}

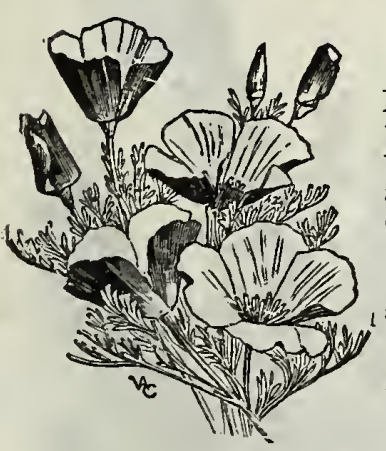

2682, Rose Cardinal, Pkt 10c.

268:, Crocea, Pkt., ioc.

2684, Golden West, Pkt., 10c.

2685, mixed, Pkt., 5c.

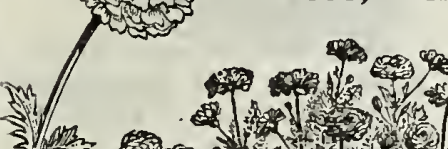

$\left\{\begin{array}{l}30 \\ 4\end{array}\right.$ 7.1.5.

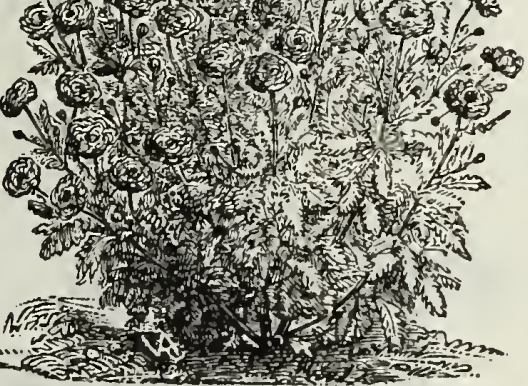

259s Chrysanthemum, cor'onarium, mixed, double, $H$. A. 18-inch. Splendid for cut flowers. Pkt., 5c.

2600 Inodorum d o u ble white, H. A., 18-inch. Very showy for border. Pkt., 10c.

2601 Tricolor album (carinatum), H. A., 18-inch. White with yellow ring. Pkt, sc.

2604 Tricolor, mixed, H. A., 18-inch. Bright and effective colors. Pkt., 5c.

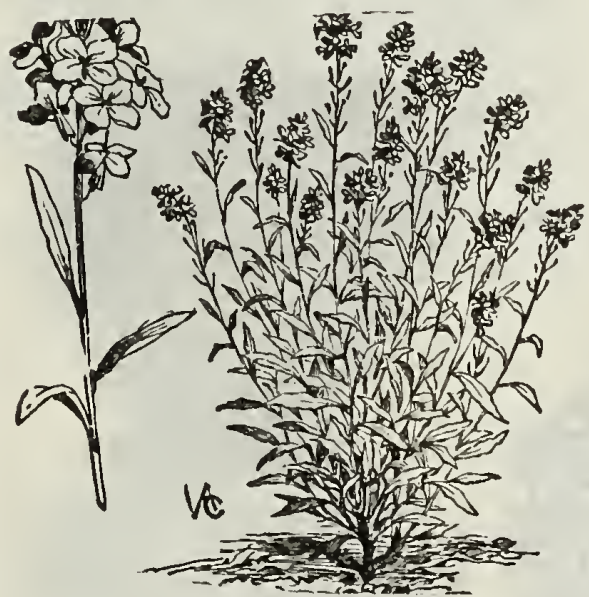

2678 Erysimum, Peroffskianum, H. A., 18-inch. Bright Orange. Very fragrant. Pkt., 5e.

2623 Cosmea, bipinnata, Empress, mixed, H. H., 42inch. Pkt., 5e.

2624 Cosmea, Mammoth Giant, mixed, H. H. A., 42inch. Pkt., 5e. charm.

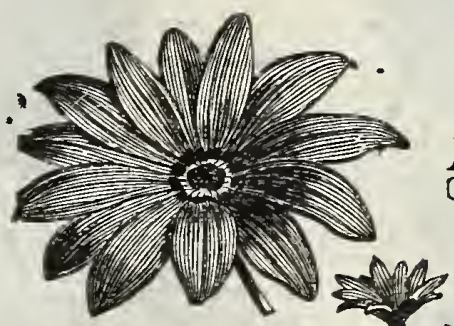

2662 Dimorphotheca, Aurantiaca hybrid, $\mathrm{H}$. A., 15-inch. African Orange Daisy. Pkt., 10c.
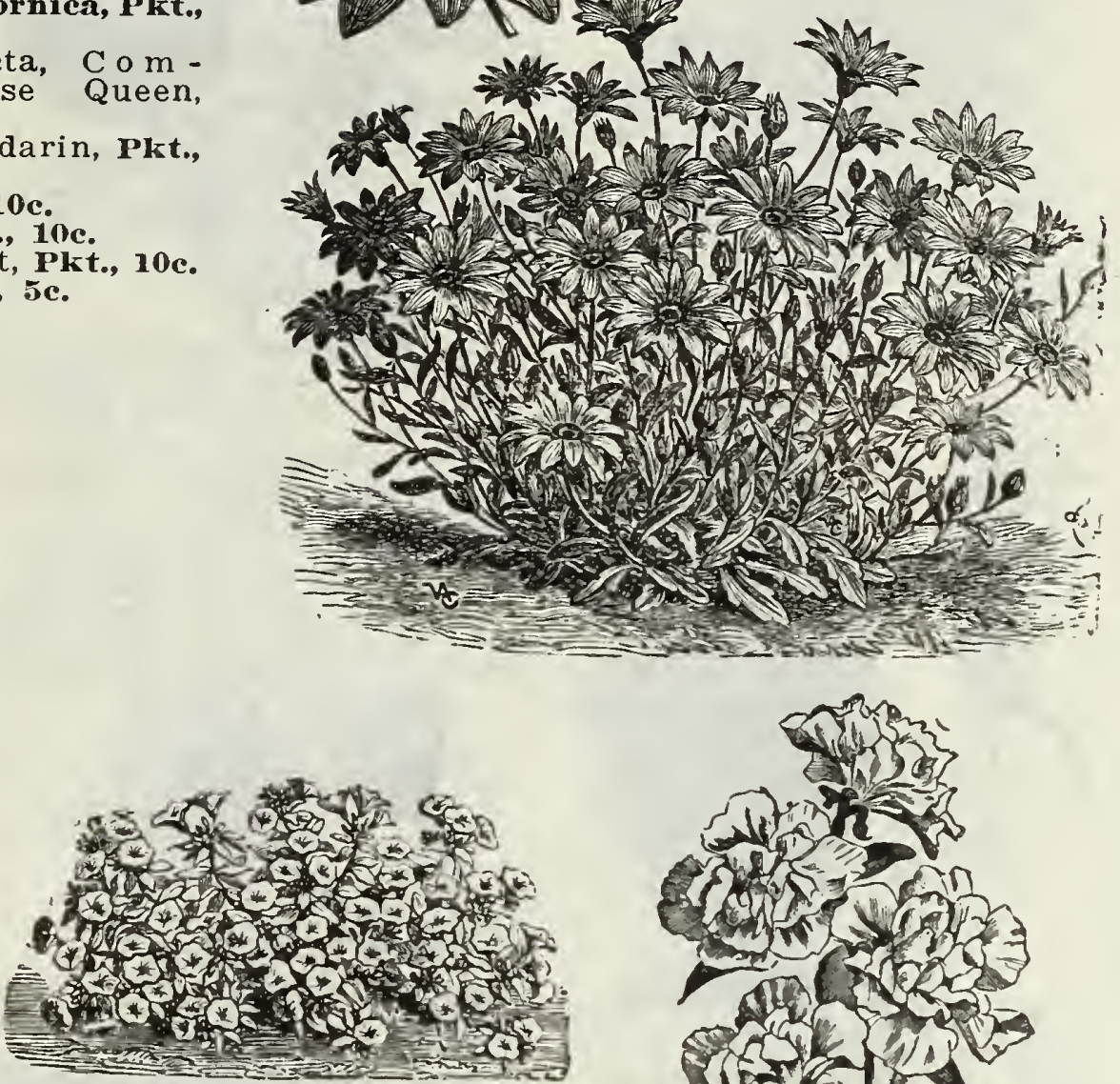

26:20 Convolvulus, Minor mixed, H. A., 12-inch. Dwarf Morning Glory. Pkt., 5e.

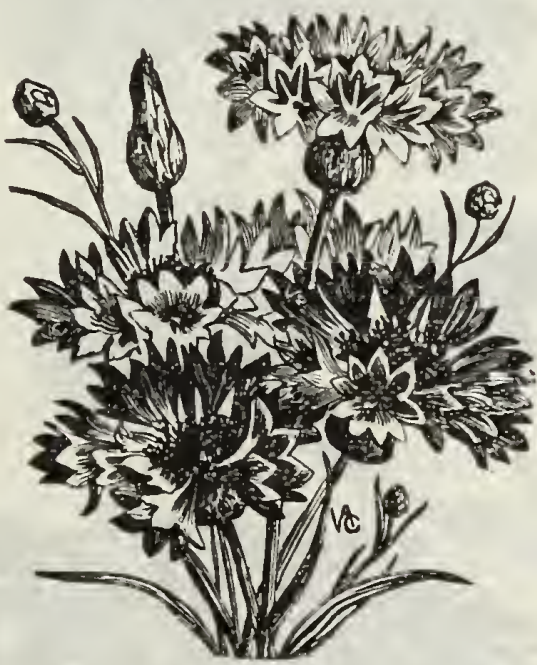

2632 Cyanus, Minor, blue, H. A., 24-inch. Pkt., 5e.

2633 Cyanus, Minor, mixed, H. A., 24-inch. Pkt., 5e.

The popular Cornflower or Bachelor's Button.

2625 Cosmea, Lady Lennox, H. H. A., 42-inch. Giant Orchid flowering. Pkt., 10c.

Cosmos do particularly well in the Northwest; their feathery foliage add to their

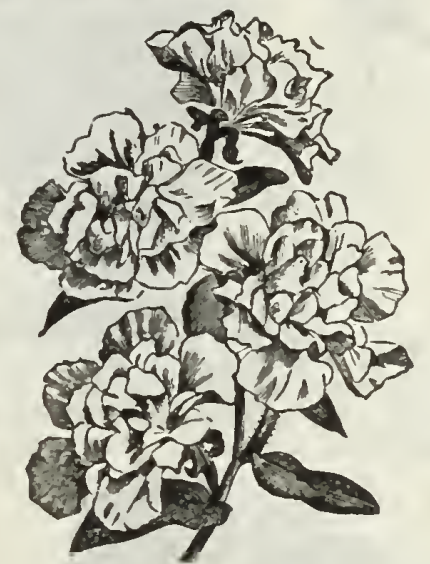

Clarkias should be in every garden; easily grown; make a gorgeous display.

a611, elegans. Pkt., 5c.

2612, elegans, d o u b le mixed, H. A., 24-inch. Pkt., 5c. 2613, pulchella, mixed, Pkt. 5e.

2614, puchella, d o u b l e. mixed, H. A., 24-inch. Pkt., 5c.

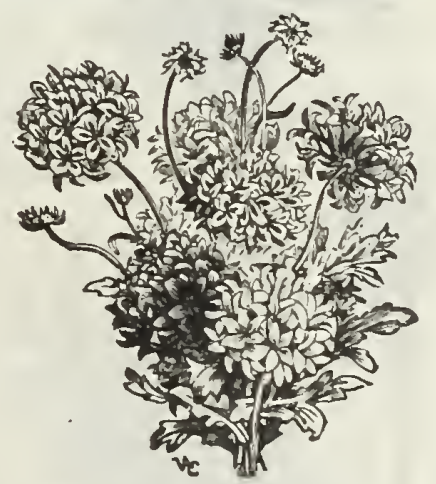

2689 Gaillardia, $p$ i c t a Blanket Flower, H. A., 12 inch. Yellow and Scarlet. Pkt., 10c.

2000 Gaillardia, Lorenziana, H. A., 12-inch. Red and Yellow. Pkt., 10c.

California Poppies make a lovely display 


\section{Showy Hardy Annuals-Continued}

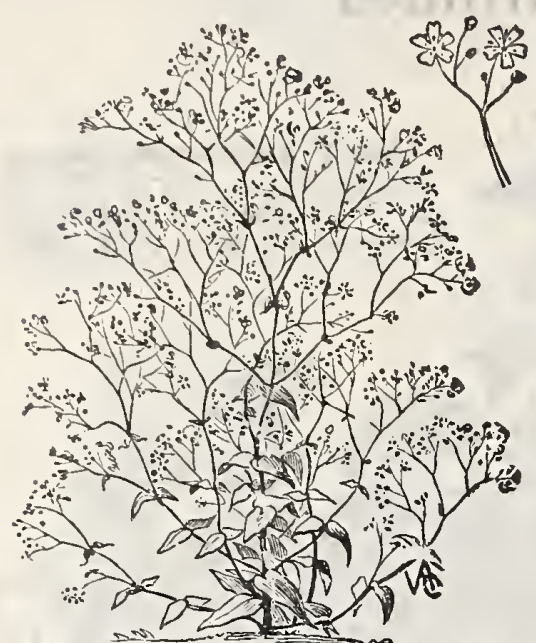

2714 Gypsophila, el e ga ns alba, H. A., 18-inch. Known as Baby's breath. Pkt., 5c.
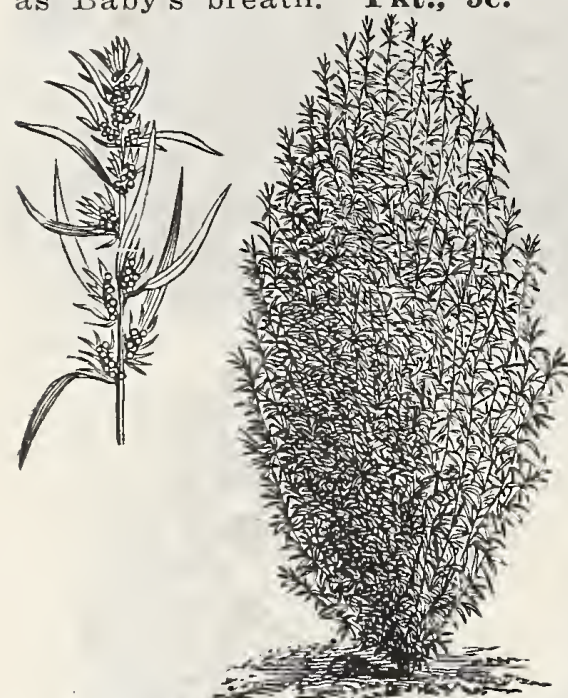

2767 Kocul cricophyla (Summer Cypress), H. A., 24 inch. The Mexican Fire Bush; beautiful foliage. Pkt., 5c.

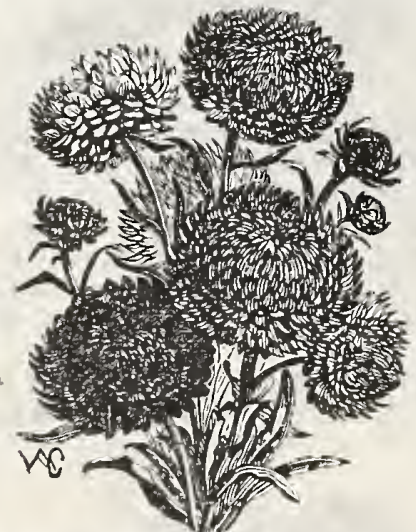

2733 Helichrysum, $m$ o $n s$, double mixed, H. A., 18 inch. Useful everlasting. Pkt., 5c.

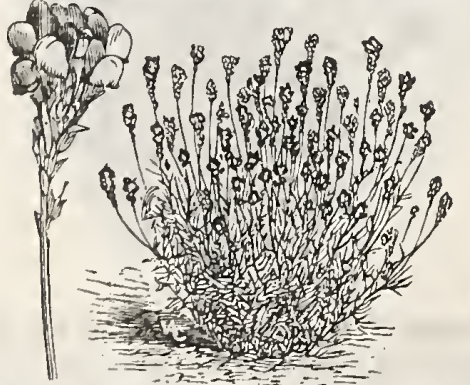

2784 Linaria, $r$ eticulat a,

H A 12-inch. Dark violet. l'kt.. 5c.

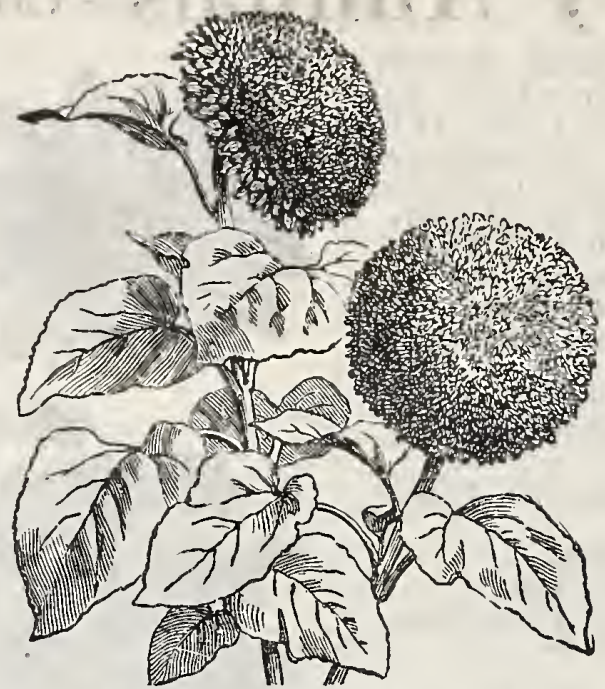

2730 Helianthus, globosus fistulosus, $H . A .72$ inch. Lemon colored, intensely double quilled. Pkt., 10c.

2728 Californicus, double, $H$. A., 60-inch. Tall double Golden Yellow. Pkt, 10c.

$2 \% 29$ Cucumerifolius Stella. $H$. A., 36 - inch. Miniature starshaped single flowers. Plt., 10c. 2731 New Red or Gaillardia flowered. Rich chestnut red color. H. A. 60-inch. Pkt., 10c.
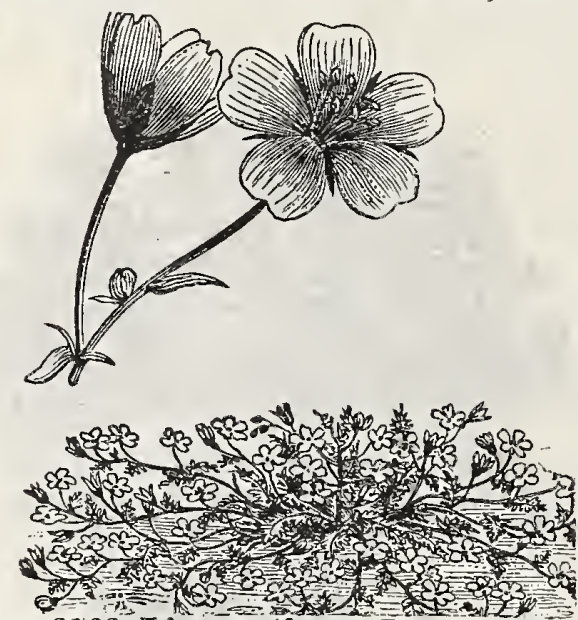
2782 Limnanthes, Douglassi fragrant, H. A., 6 inch. Beautiful perfume; early. Splendid for bees. Pkt., 5c.

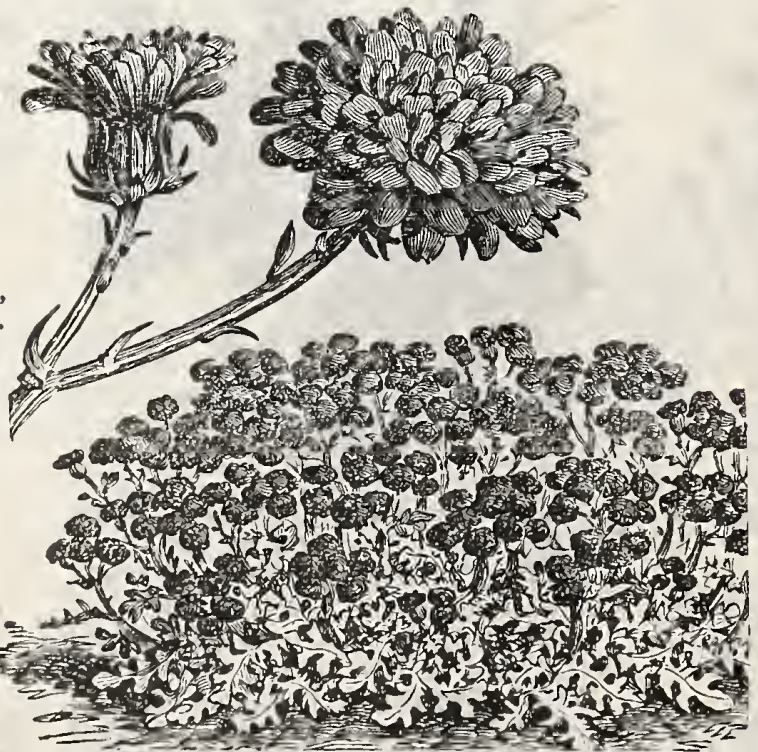

2765 didculates Uwal Uuunte tulied, H. A., 20 inch. Beautiful double flowers, useful for cutting. Pkt., 10c.

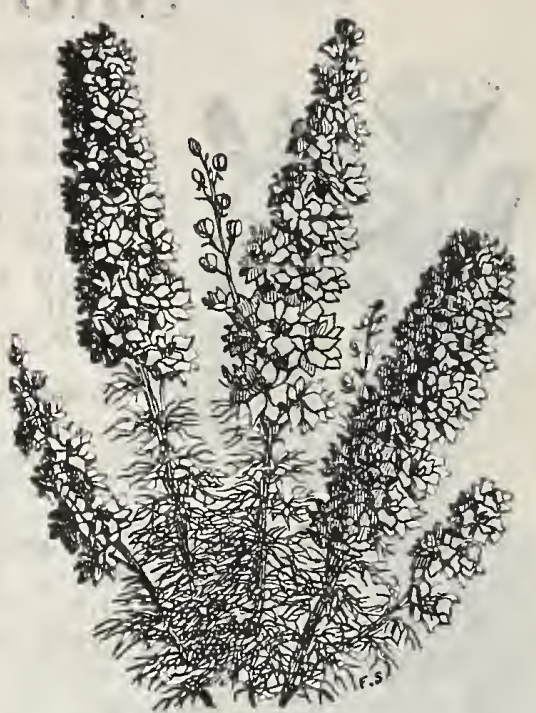

2776 Larkspur, tall branching mixed, H. A., 12 inch. Plit., 5 c. $27 \%$ Larkspur, d o u b l e tall rocket mixed, Pkt., 5c.

$27 \% 8$ Larkspur, dwarf hyacinth flowered, H. A., 12-inch. Pkt., 5c. Beautiful annuals, succeed anywhere and give charming effect.

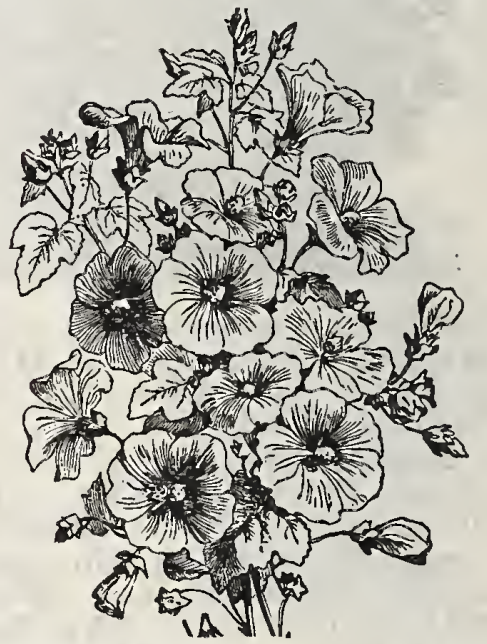

2780 Lavatera, $t \mathrm{rim}$ estris, white H. A. 36 inch. Pkt., 10c.

2781 Lavatera, $t \mathrm{r}$ i mest $\mathrm{r}$ is red, H. A., 36 inch. Pkt., 10c. Handsome profuse flowering.

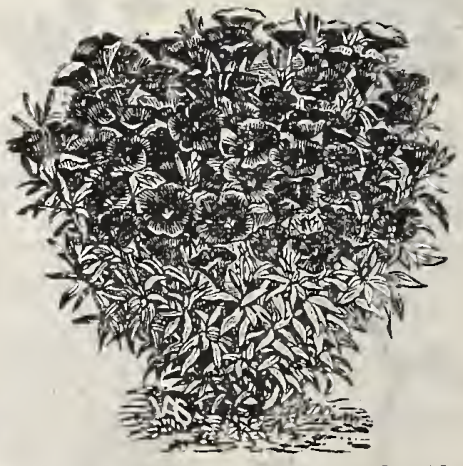

Nothing can equal the Godetia for quickly producing a blaze of flowers. Our selection will give a ma nnificent display.

$2703 \mathrm{~L}$ a d y Albemarie,

H. A. 12 inch. Pkt., 5c.

2704 L a d y Satin Rose,

H. A., 12 inch. Pkt., 5c.

2705 Mixed Tall Varieties, H. A., 18-inch. Pkt., 5c.

$2706 \mathrm{D}$ w a $\mathrm{f}$ Varieties.

H. A., 12-inch. Pkt., 5e.

"Say It With Flowers" of your own growing 


\section{Showy Hardy Annuals-Continued}

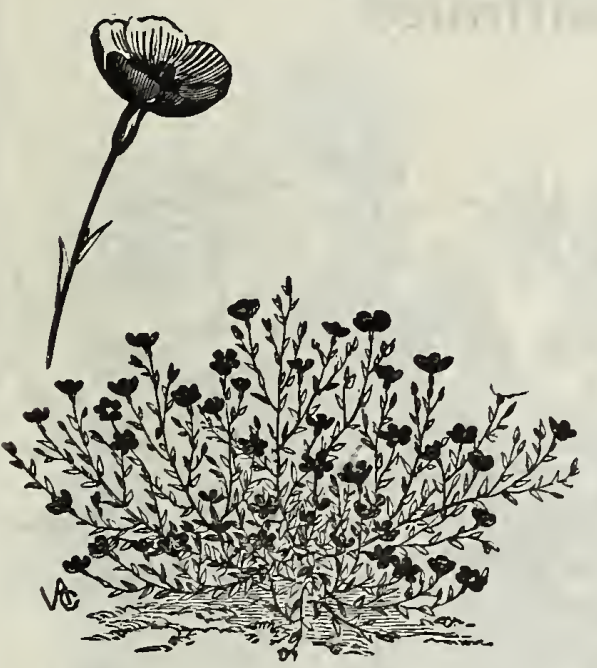

2786 Linum, grandiflorum rubrum H. A. 18 inch. Old fashioned Scarlet Flax, Pkt., 5c.

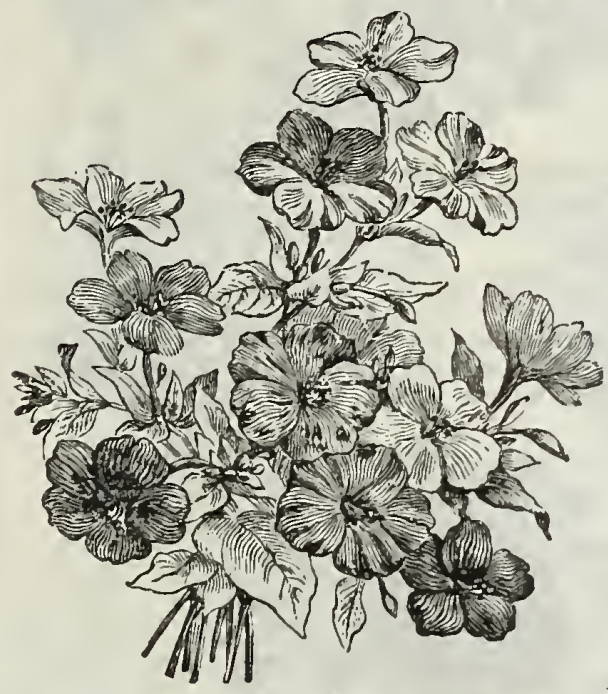

2821 Marvel of Peru (Four O'Clock) H. A. 30 inch. Ea
grown; very showy. P'kt., 5e.

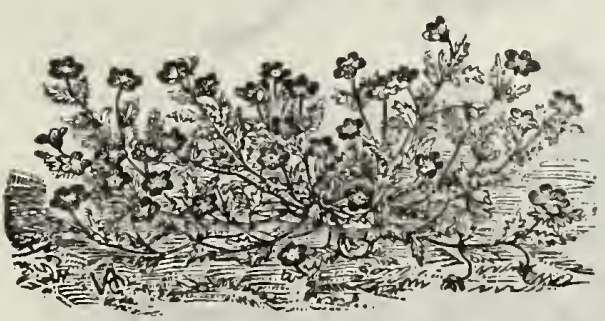

2864 Nemphila, Insignis, Bright Blue. H. A. 6 inch. Old fashioned edging plant. Plit., 10c.

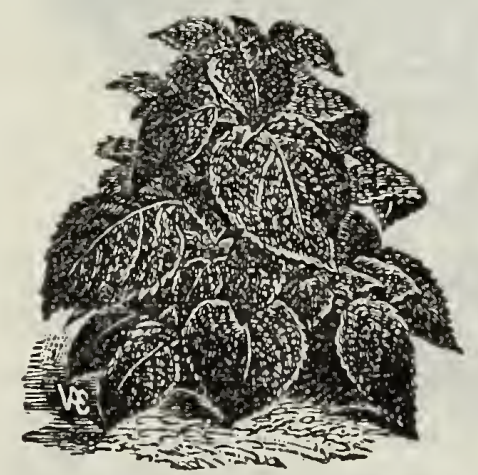

2894 Perilla, Nankinensis H. H. A. 18 inch. Beautiful wine colored foliage. Pkt., 10c.

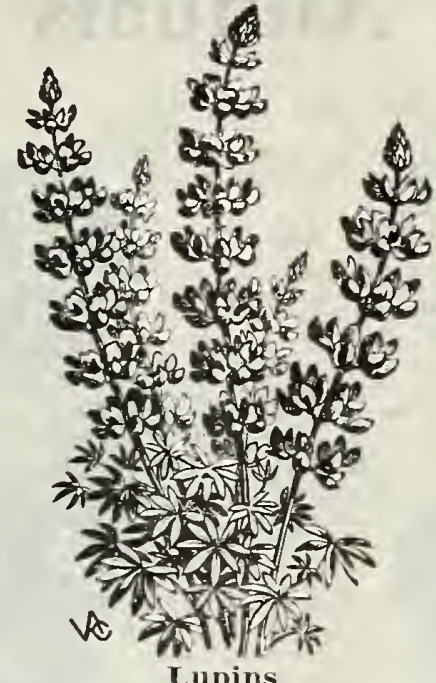

H. A. 30 inch Each pkt., 5c $279 \%$ Large Blue.

2798 Large White

2799 Large Rose.

2800 Large Yellow.

Lupins with their silvery foliage and sprays of pea like fowers, make a splendid background for a flower border.

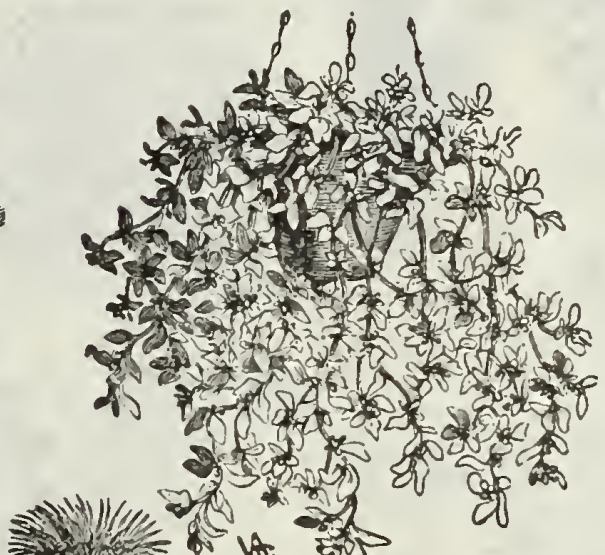

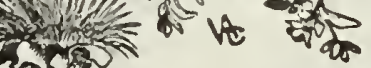

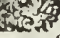

2827 Mesembryanthemum, Crystallinum H, II, A. 3 inch. Ice Plant, easily grown: most interesting. Plit., 5c.

2996 Inpinus. Annual Varieties, Mixed H. A. 18 inch. Foliage and flowers make gorgeous display. Plkt., 5c. $\$ 813$ Malope, Grandiflora $H$ A. 24 incli. Old fashioned Scarlet Mallow. Pkt., 5c

2822 Matthiola, bicornis. (Evening scented Stock) H. A 1\% incli. Emits an exquisite perfume after sundown. Ilit. 5c.

\section{Nasturtium}

Our selection of Nasturtiuns will be found to contain a very choice assortment of colors. The dwarf varieties are splendid for edgings or borders, and the tall, for covering unsightly corners or trellises. See also Hardy Annual Climbers.

Tom Thumb. H. A. 12 inch each. Pkt., sc.

2850 Aurora Rosy Apricot.

2851 Enu. of India, Crimson Scarlet.

2853 King Theodore, Dark Foliage.

2854 Queen, Maroon, Crimson variegated leaves.

2856 Mixed, Choice Selection.

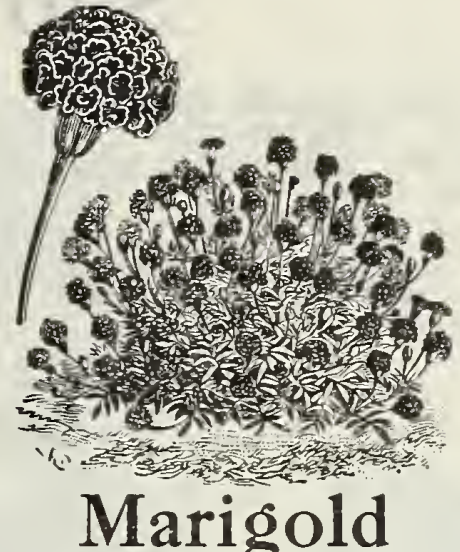

H. H. A. Each pkt. 10c

Our strains of Marigolds are exceptionally fine; will produce a large percentage of double flowers of exquisite colors, quite distinct from almost anything else you can grow in the garden.

2814 African Orange. 24 inch. 2815 African Lemon. 24 inch.

2816 French MIixed. 18 inch. 2817 French Dwarf Mixed. 6 inch.

2818 French Gold Striped Selected. 18 inch.

2819 Frencl Legion of Honor. 6 inch.

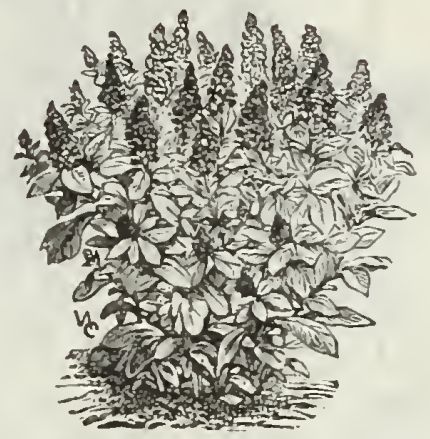

\section{Mignonette}

Our strains of the old fashioned Mignonette are very fine large fowers, and deliciously scented. Goliath and Machet varieties are splendid for indoor culture in pots, as well as outdoor use. 12 inch

2828 Large flowering. Pkt., 5e. 2829 Golden Queen. Plit., 10c. 2830 Goliath. Pkt., 10c. 2831 Machet. Pkt., 10c.

2823 Matricaria, Eximia, Double White H. H. A. 12 inch. Plit., 10c.

282t Nana Golden Ball, Double H. I. A. 12 inch. I'kt., $10 \mathrm{c}$

Beautiful daisy-like flowers; form nice shaped bushy plants.

2861 Nemesia, Compacta. Blue Gem H. H. A. 12 inch. 2862 Compacta, White Gen H. II. A. 12 inch. Pkt., 10c. 2863 Strumosa Nana Conpacta H. II. A. 12 inch. Splendid plants for pots or borders.

Charming bushy plants for border; beautiful butterfly flowers, each pkt., 10c.

2865 Nicotiana, Affinis, Pure White H. H. A. 36 inch. Pkt.,10 2866 Affinis, Hydrids. Mixed H. H. A. 36 inch. Pkt., 10c.

The flowering Tobacco Plant: very fragrant and beautiful.

Try our Nasturtium. They will please you. 


\section{Showy Annuals-Continued}

2868 Nigella, damascena, double. H. A. 18incli. Pkt., 5c.

2869 Miss Jekyll, azure blue. H. A. 18-inch. Plit., 5c.

28\%0 Hispanica. H. A. 18-inch. Pkt., 5c.

Love-in-a-mist; curious and interesting plants, splendid for mixing with California Poppy and Godetia.
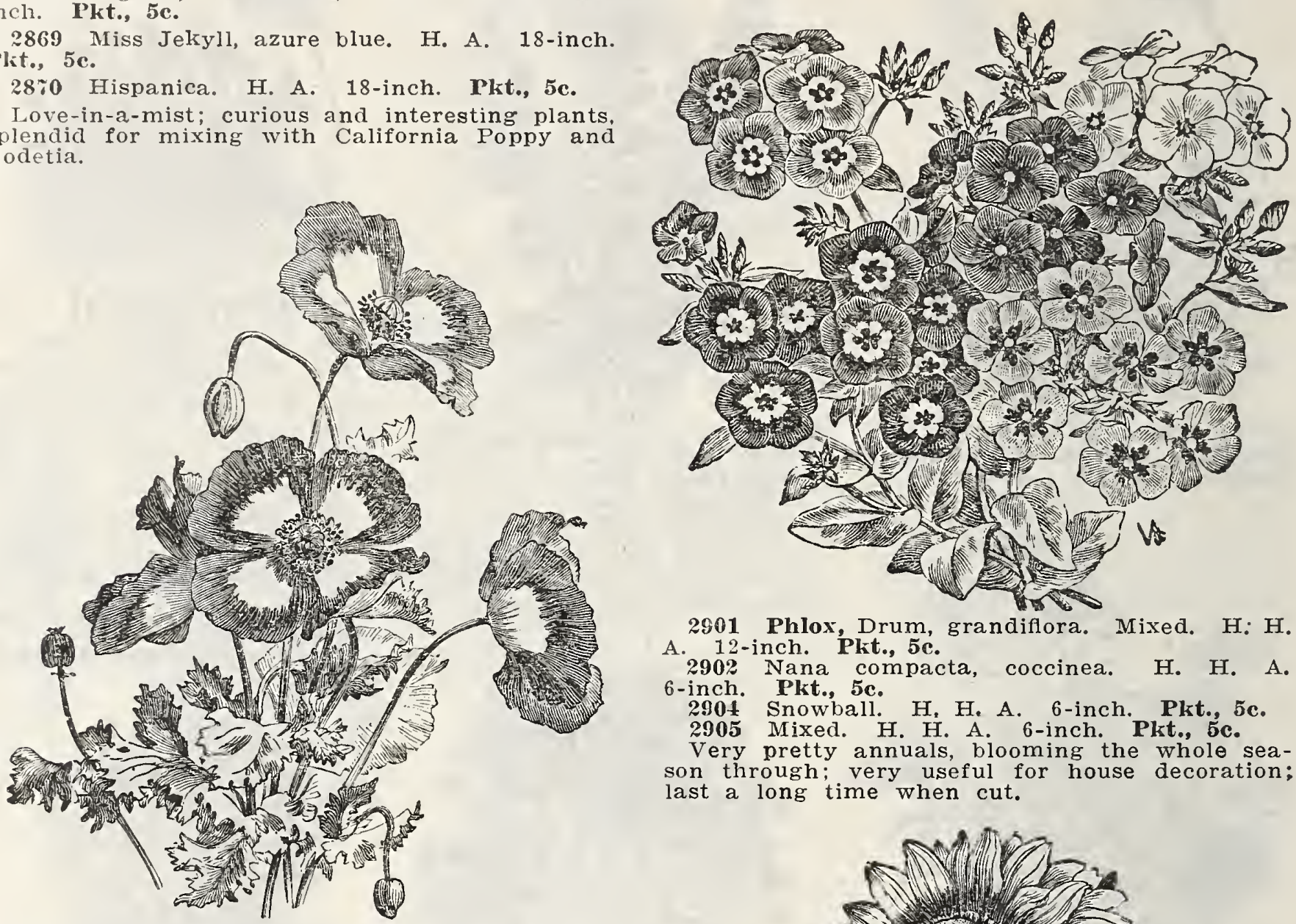

2901 Phlox, Drum, grandiflora. Mixed. H: H. A. 12-inch. Pkt., 5c. 6-inch. Pkt., 5c.

2904 Snowball. H, H. A. 6-inch. Pkt., 5c.

2905 Mixed. H. H. A. 6-inch. Pkt., 5c.

Very pretty annuals, blooming the whole season through; very useful for house decoration; last a long time when cut.

2911 Poppy, Danish Flag. H. A. 24-inch. Single flowered. White with red band. Pkt., 10c. 2908 Carnation, flowered. Mixed. H. A. 24-inch. Choice double flowers. Pkt., 5c.

2909 Ranunculus flowered. H. A. 24-inch. Sometimes called the French poppy. Beautiful. Pkt., 5c.

2912 Japanese Pompon, mixed. H. A. 24-inch. Small; double; perfectly formed flowers. Pkt., 5c.

2914 The Shirley, mixed colors. H. A. 24inch. An exquisite strain of this chaste flower. Pkt., 5c.
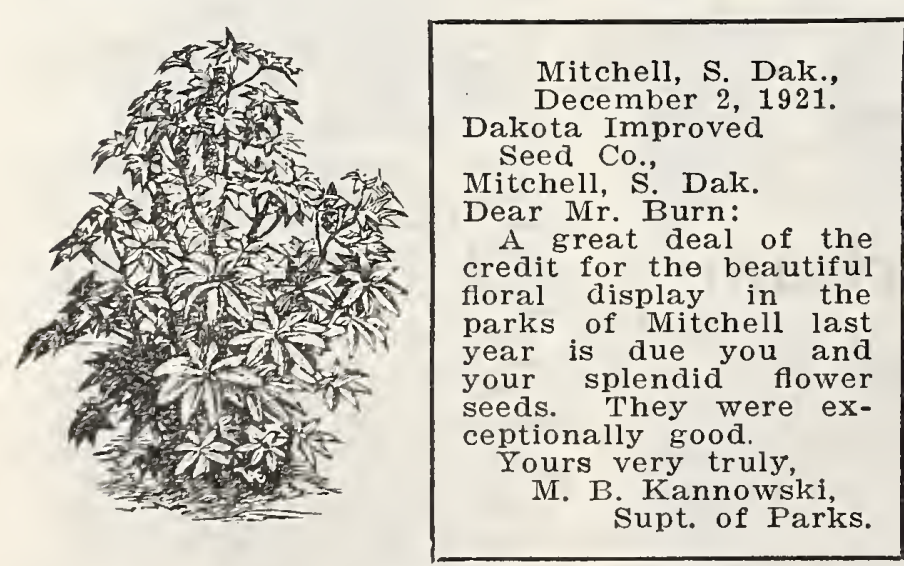

2938 Ricinus Gibsonii. H. H. A. 60-inch.

Pkt., 5c.

2939 Sanguineus. H. H. A. 60-inch. Pkt., 5c. 2940 Zanzibariensis, mixed. H. H. A. 60-inch. Pkt., 5c.

The beautiful large colored leaves produce a nice effect, popularly known as Castor Oil plant.
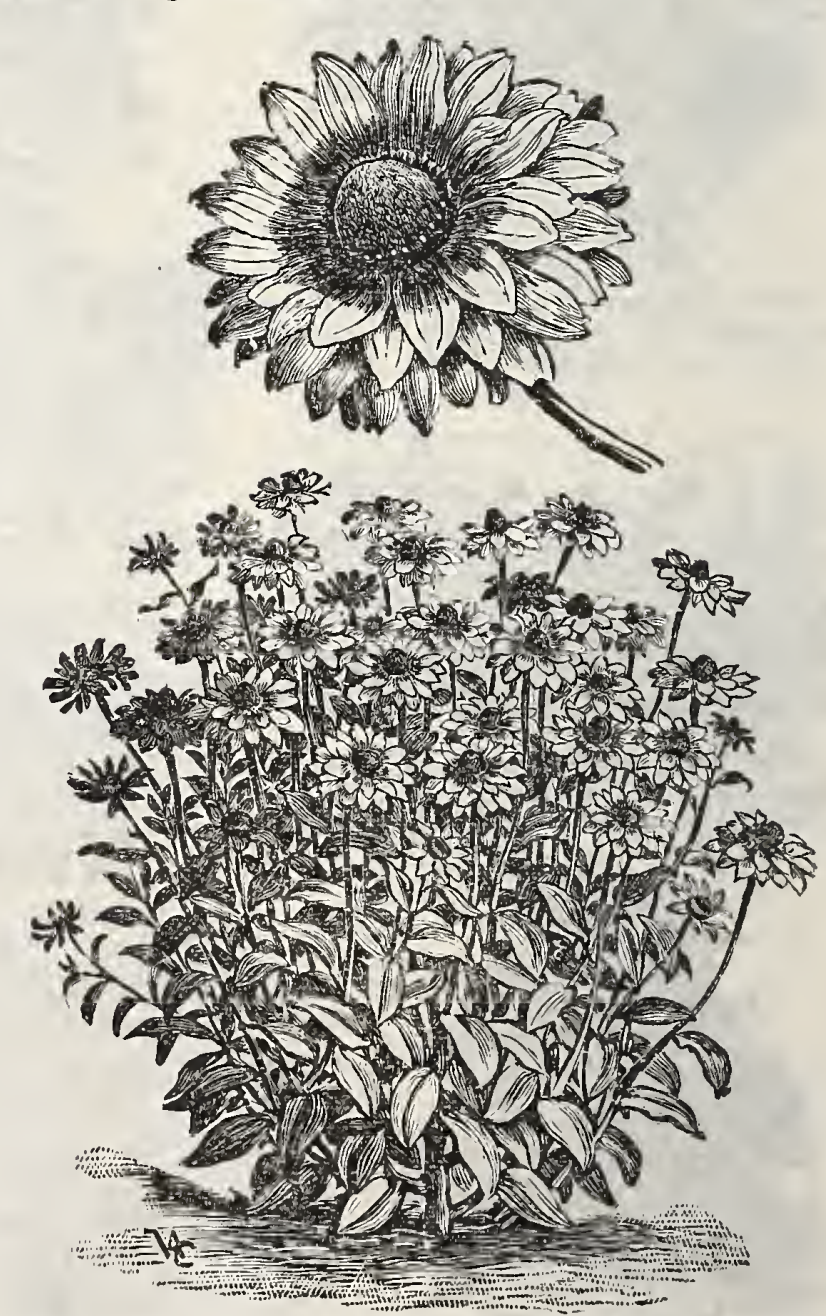

2941 Rudbeckia, bicolor superba hybrida. Produces deep golden flowers. H. A. 24-inch. Pkt., 10c.

What about a bed of Poppies. this year 


\section{Showy Annuals-Continued}
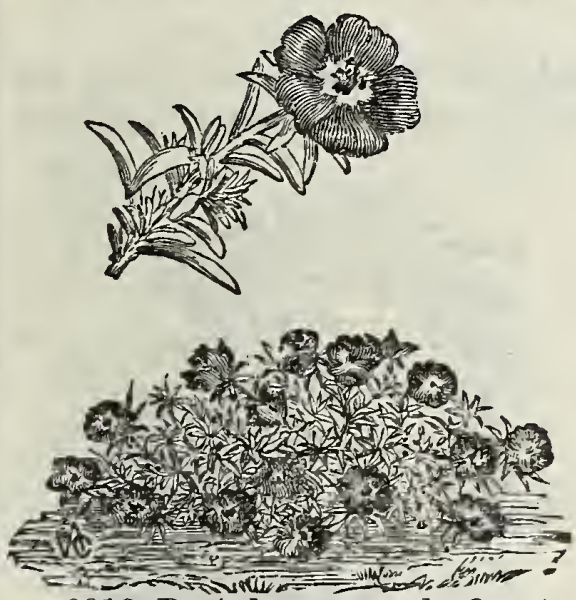

2916 Portulaca grand, finest large flowers. H. H. A. 6-inch. Plt., 5c.

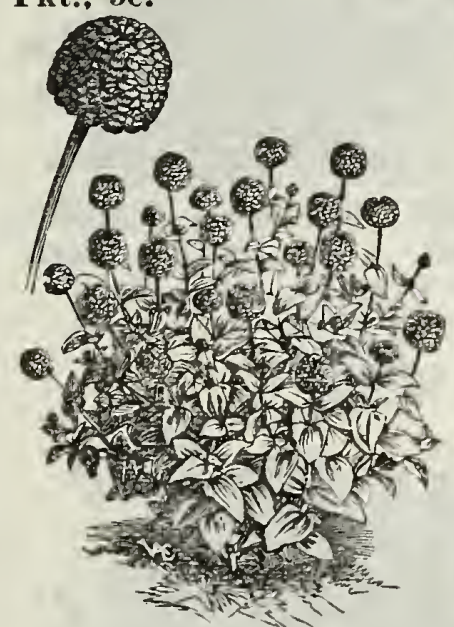

3026 Zinnia elegans, double. Mixed. H. H. A. 24-inch. Pkt., 10c.

3033 Elegans, Liliput. Mixed. H. H. A. 12-inch. Pkt., 10c.

Zinnias do exceptionally well in the Northwest. Our strains are magnificent. By planting the large at the back and smaller in front, a grand show can be had.

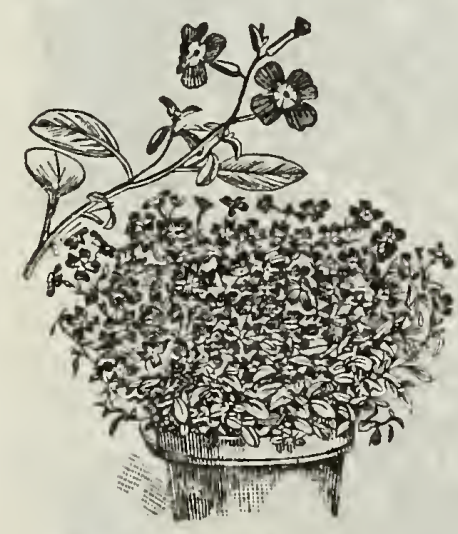

3015 Virginian Stock. Mixed. H. A. 9-inch. Very useful for edging. Pkt., 5c.

2960 Schizanthus papilionaceaus. H. A. 18 inch. Lilac and white spotted. Pkt., 10c.

2961 Wisetónensis. $H$. H. A. 18-inch. Valuable as a house plant. Pkt., 10c.
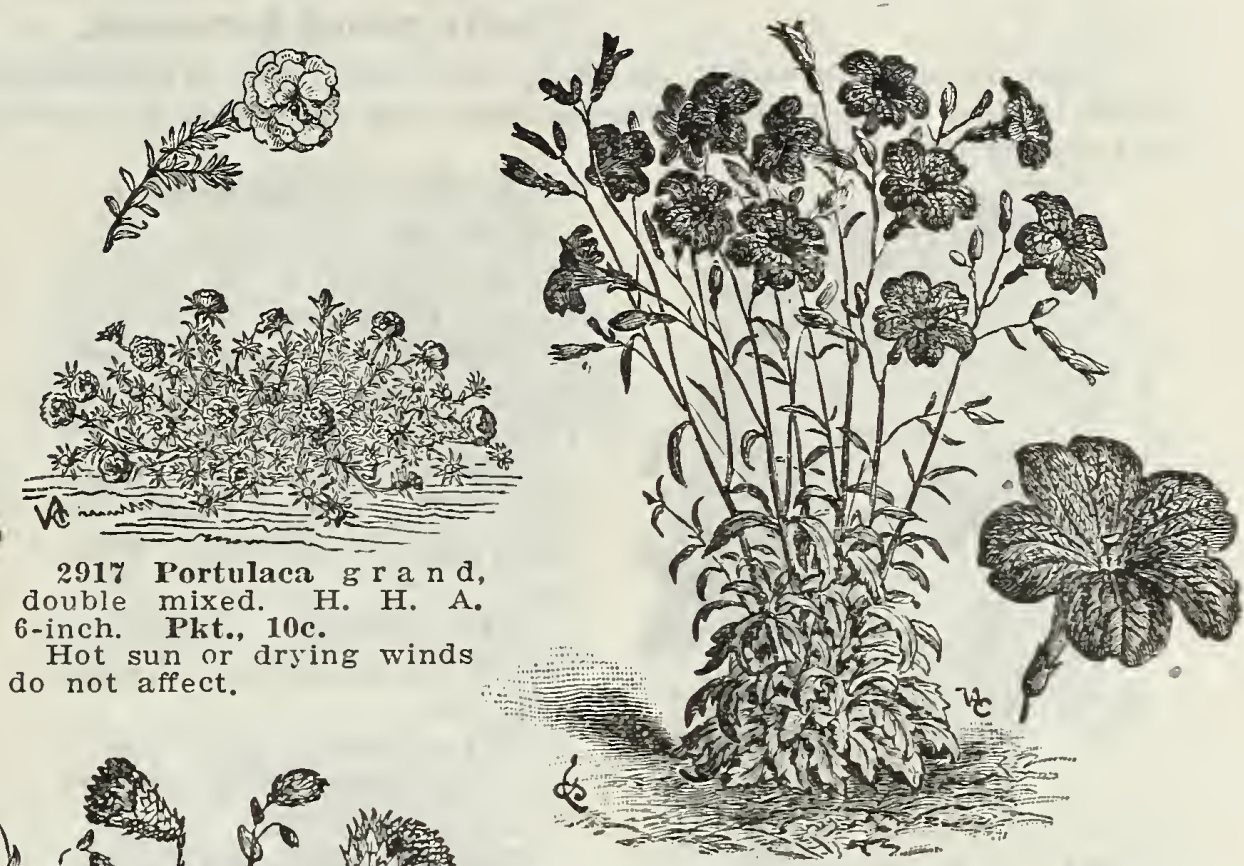

291 ry Portulaca g r a $\mathrm{n}$, double mixed. H. H. A. 6-inch. Pkt., 10c.

Hot sun or drying winds do not affect.

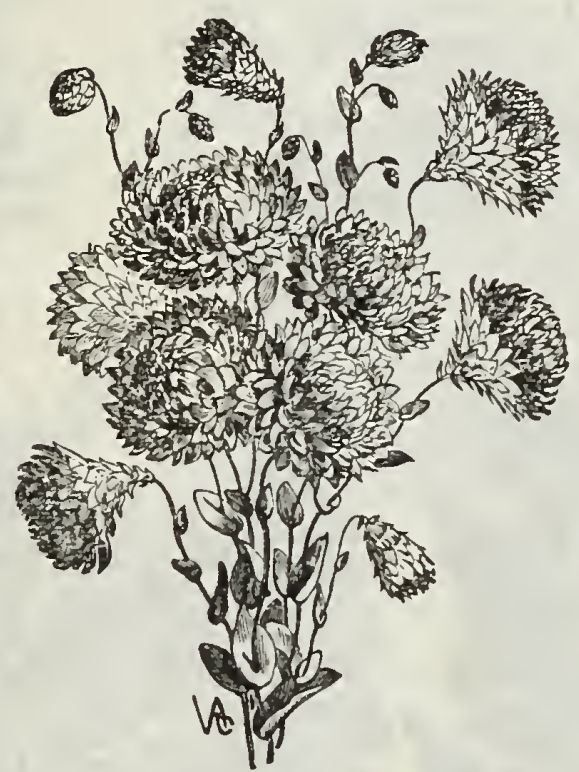

2937 Rhodantho Manglesii, rose. H. H. A. 12-inch. useful everlastings. 5c.
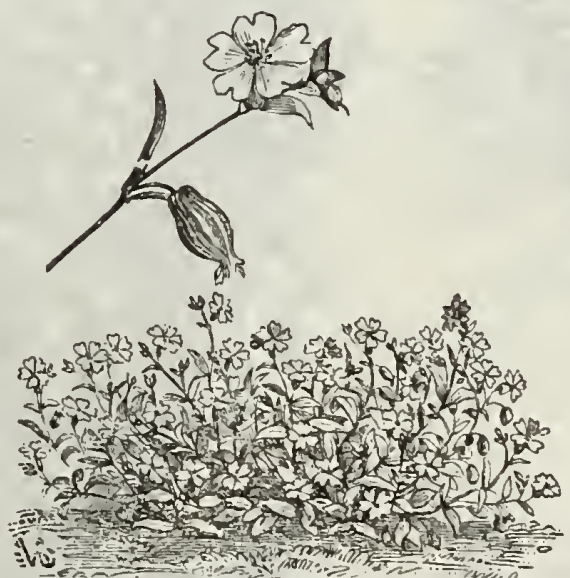

2963 Silene, pendula compacta, pink. H. A. 6-inch. Charming for edging or rockeries. Plkt. 5c.

3035 Zea Japonica, variegata. H. A. 48-inch. Leaves beautifully striped. Plit., 10c.

3023 Wallfower, annual. Single mixed. H. A. 12-inch. Can be grown like other annuals. Pkt., 10c.

For Sweet Peas see page 35
2952 Salpiglossis grandiflora, mixed.
H. H. A. 24-inch. One of our most

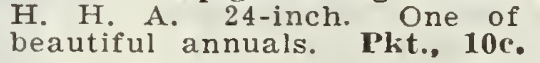

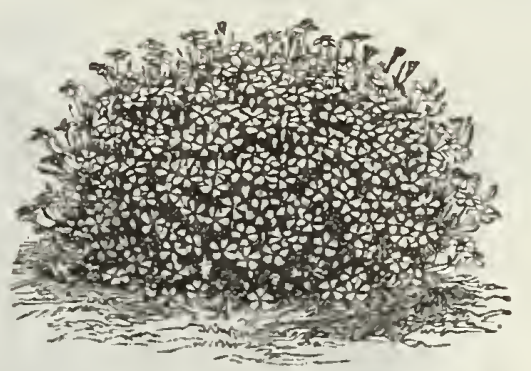

2993 Tagetes, signata pumila. rellow. H. H. A. 6-inch. A gem for edging or pots. Pkt., 5̃c.

\section{Stocks}

Our stocks are saved from one of the finest strains in Europe, and will delight and satisfy you.

29\%0 Dwarf, large nowering, ten week, white. H. H. A. 12-inch. Pkt., 10c.

2971 Flesh pink. H. H. A. $12-$ inch. Plkt., 10c.

2972 Crimson. H. H. A. 12 inch. Pkt., 10c.

2973 Violet. H. H. A. 12-inch. Pkt., 10c.

2974 Mixed. H. H. A. 12-inch Plit., 10 c.

2975 Frincess Alice. H. H. A. 12 -inch. Pearly white, very early. I'kt., 10c.

2980 Sweet Sultan, purple. H. A. 24-inch. Pkt., 5c. 2981 White. H. A. 24-inch. Pkt., 5̃c.

2982 Yellow. H. A. 24-inch. Pkt., 5c.

2983 Mixed. H. A. 24-inch. Pkt., 5c.

Graceful feathery flowers. One of the most useful annuals for cut flower decorations. 


\section{Hardy Annual Climbers}

Easily raised from seed.

May be either sown in pots or boxes and transplanted, or if preferred, may be sown in the open ground where they are intended to flower. Gourds are easily grown and very interesting.

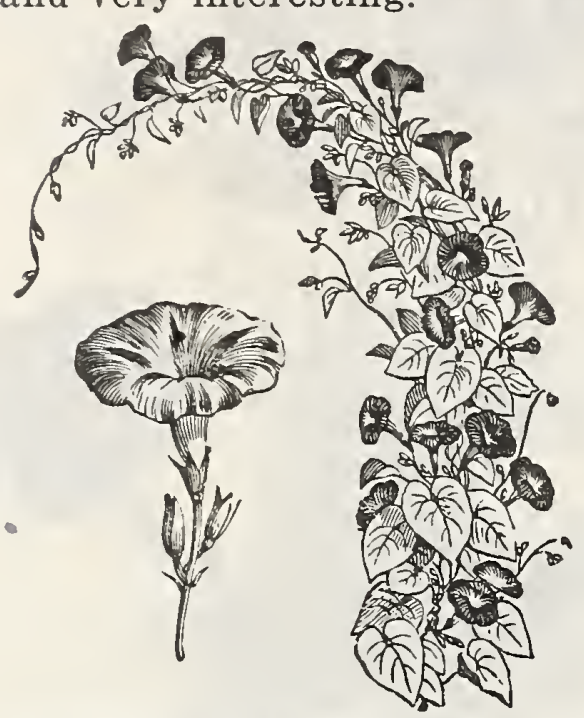

2621 - Convolvulus Major, mixed. Tall Morning Glory. Pkt,, 5c.
Gourds-Ornamental

2707-H e r c u les Club Fruit grows 3 to 4 feet long. Pkt., 5c.

2708-P ow d e $r$ Horn. Very interesting Go $\mathrm{u} \mathrm{rd}$. Pkto, 5c.

2709-Bottle, the original Thermos. Used by pilgrims in the East. Pkt., 5c.

2710-Dipper. M a kes really an excellent dipper. Pkt., 5c.

2711-Dishcloth. Fru it makes a dishcloth, always sweet. Pkt., 5c.

2712 - Egg - s h a p ed, white. Fruit may be used as nest egg. Pkt., 5c.

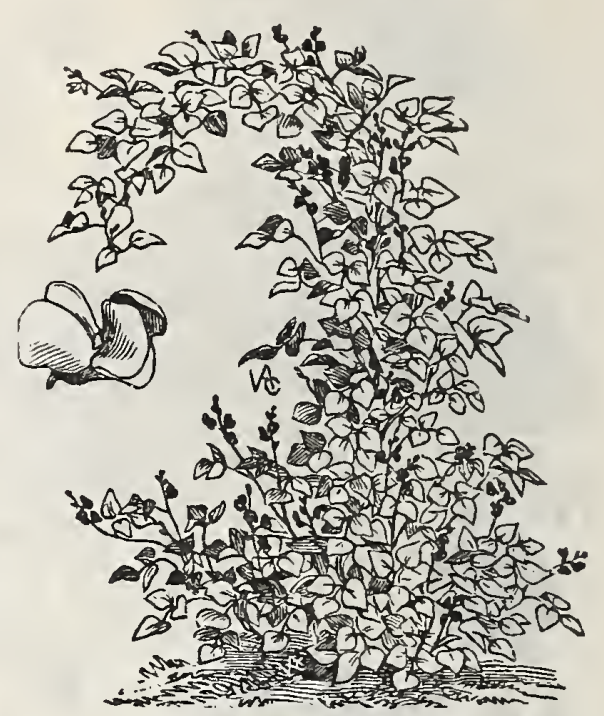

2663 Dolichos - Lablab, mixed. Hyacinth Bean, very pretty. Plkt., 5c.

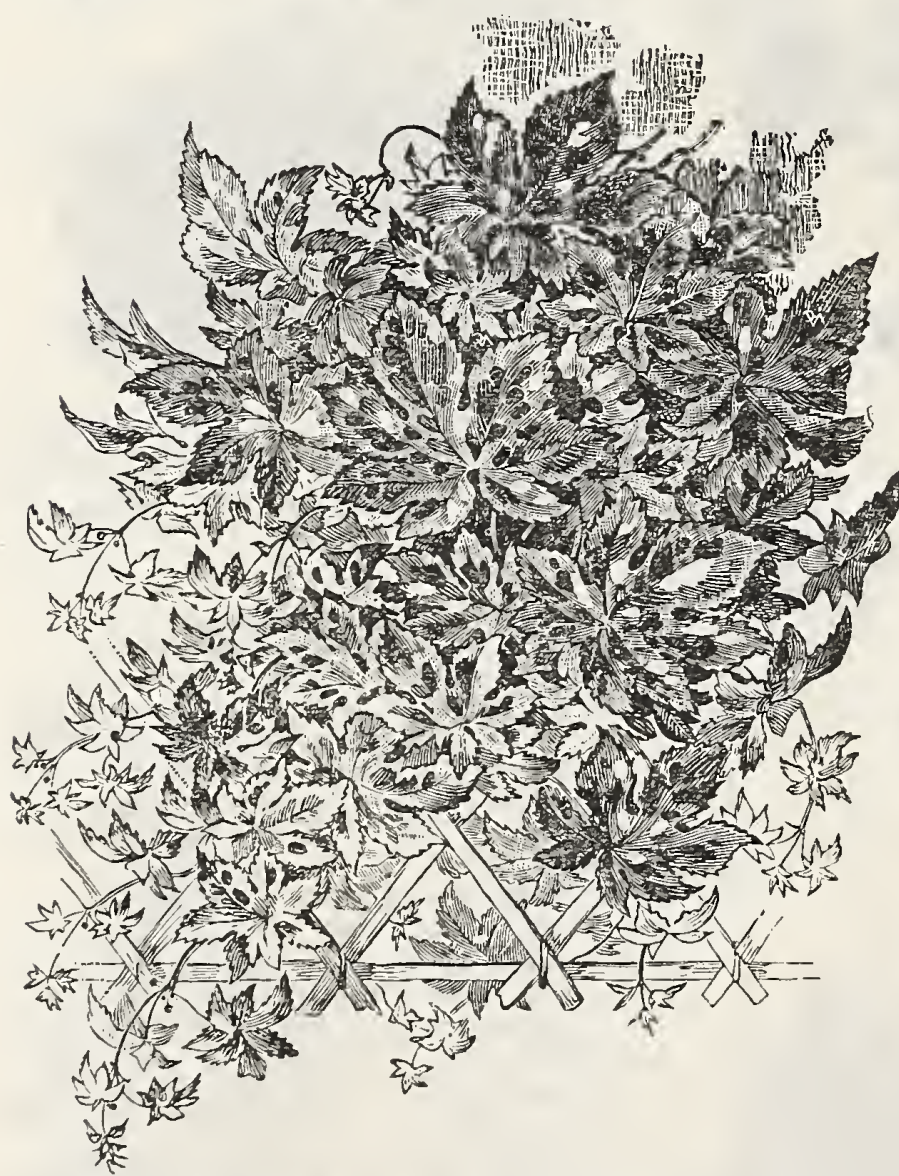

2740 Humulus-Japonicus, $\mathrm{J}$ a $\mathrm{p}$ a $\mathrm{n}$ e s e Hop. A very rapid growing climber. Pkt., 5s.

2741-Variegated. Fine silver striped leaves. Pkto 10c.

2674 Echinocystis-Wild $\mathrm{Cu} \mathrm{c} \mathrm{u} \mathrm{m}$ b e r. Splendid for verandahs. Pkt., 5c.

2860 Nasturtium-Tall, mixed. Fine for trellis or covering unsightly corners. Pkt., 5c.

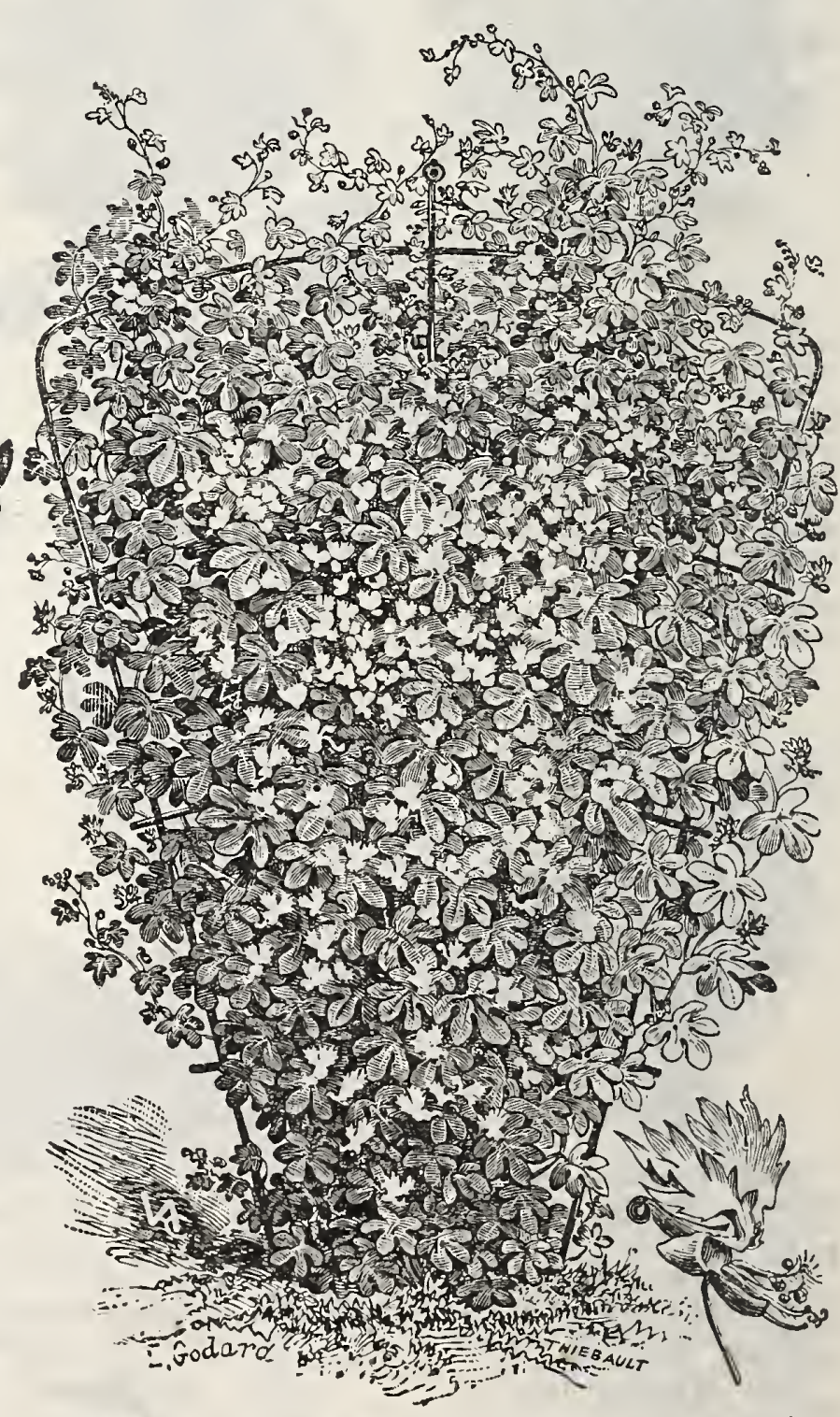

2996 Tropaeolum, canariense-The $\mathrm{Ca}$ nary Bird Flower. Pkt., 5c. 


\section{Hardy Perennials and Biennials $\begin{gathered}\text { Easily Raisced } \\ \text { rirm } \text { secd }\end{gathered}$ \\ Those marked "H. P." are perennials and "H. B." biennials. Can both be treated} in the same way. May be sown in the Spring indoors and transplanted. If this method is adopted will be in bloom the first year. They may be also sown in June or July out of doors and will remain out all winter if given slight covering and can be transplanted

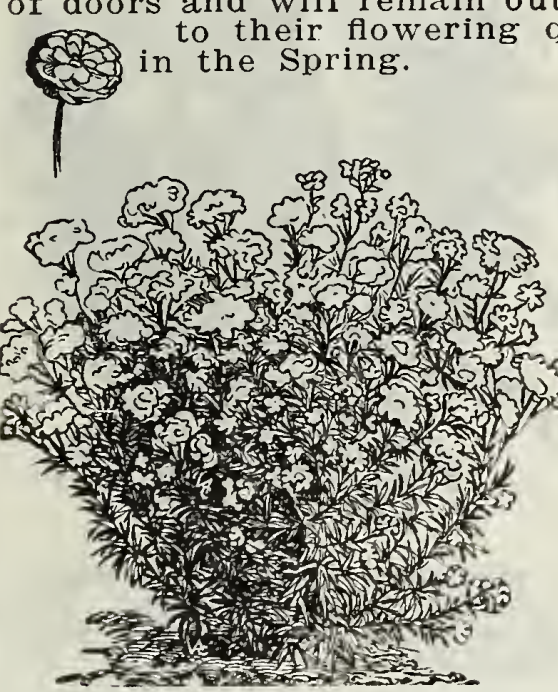

2502 Achillea, ptarmica, f. pl. The Pearl, H. P., 18 inch. Double White, splendid for cutting. Pkt., rne.

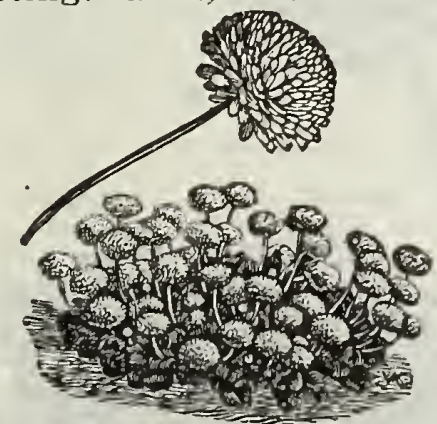

2561 Bellis Perennis, mons, double, mixed, H. P., 6 inch. Double Daisies; sow early. Pkt., 10c.

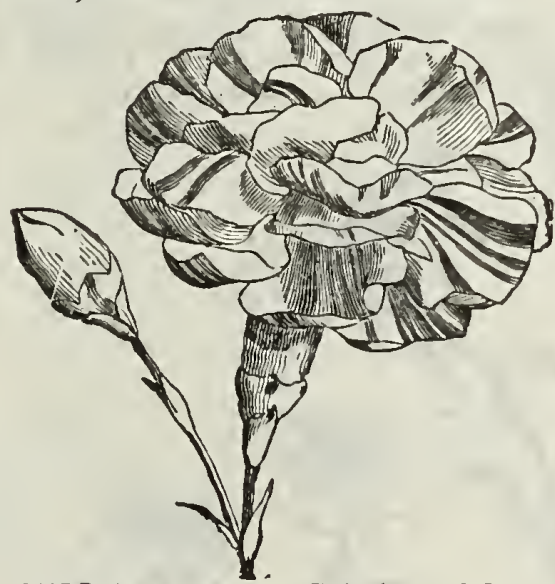

258s Carnation, Riviera Market, H. P., 24 inch. Pkt., 15 . Beautiful double flowers, extra early, free blooming, flower six months after sown. 2589 Carnation, Grenadin, double, H. P., 18 inch. Pkt., 10c.

2590 Carnation, Chabaud's or Earliest French, H. P., 24 inch. Pkt., 15e.

2591 Carnation, Margarita Semi Dwarf, mixed, H. P. 9 inch. Pkt., 10c.

Sown indoors in February will bloom in August.

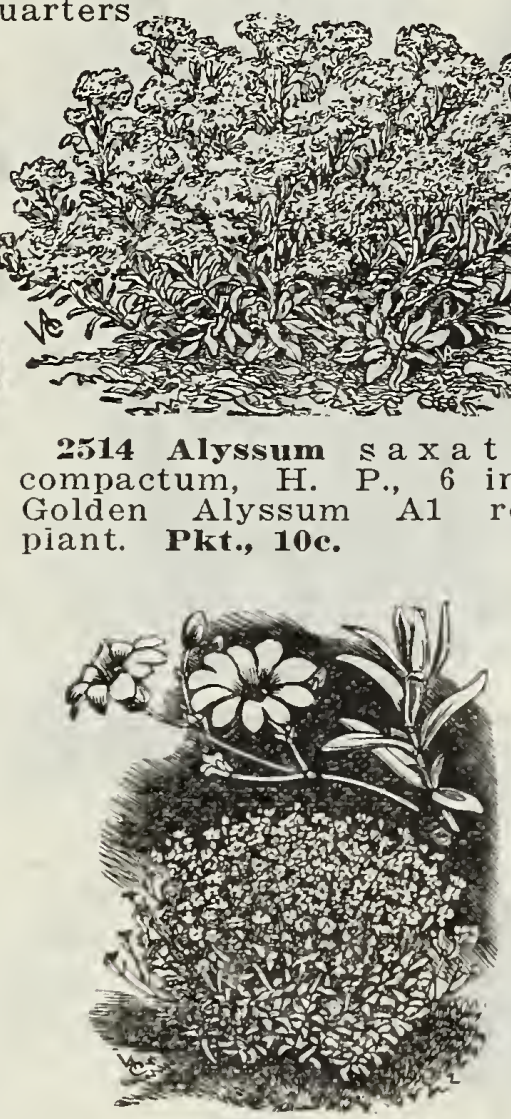

2597 Cerastium, Tomentosum, H. P., 6 inch. Silvery foliage; fine for ribbon. P'kt. 10e.

2520 Antirrhinum, majus, mixed, H. P., 24 inch. Pkt. 10c.

25:21 Antirrhinum, majus, dwarf, mixed, H. P., 12 inch. Pkt., 10c.

252. Antirrhinum, majus, Tom Thumb, mixed, H. P., 6 inch. Pkt., 10c. Three of the very finest types and strains of the old fashioned Snapdragon, everyone should grow these.

2523 Anuilegia, new single hybrids, H. P., 24 inch. Columbine, magnificent spurs Pkt., 10c.

2524 Aquilegia, mixed, double, H. P., 24 inch. Very beautiful colors. Pkt., 10c.

2525 Arabis, Alpina (Mountain Snow), H. P., 6 inch. Beautiful whit e flowel. Pkt., 10e.

2605 Chrysanthemum, maximum, King Edward VII, $H$. P., 18 inch. Grand for cutting and borders the "White Marguerite." Pkt., 10c.

Try our beautiful Carnations

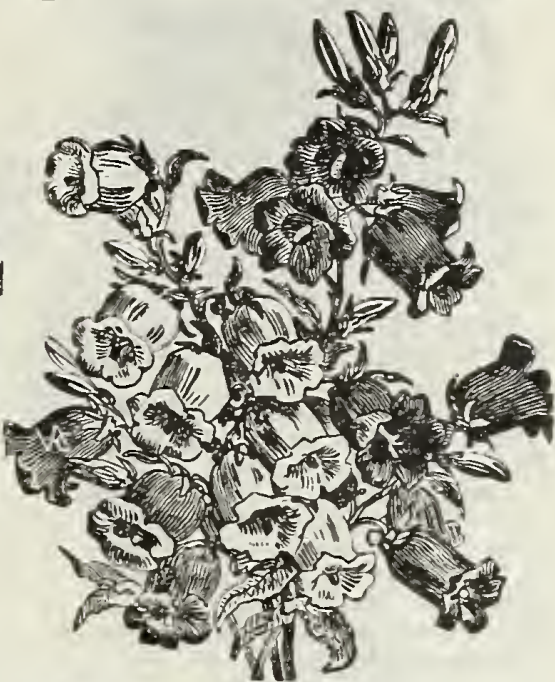

2584 Canterbury Bells, single mixed, H. P., 30 inch. The old fashioned single Pkt., 10c.

2585 Canterbury Bells, double, mixed. H. P., 30 inch. The old fashioned double. l'kt., 10c.

2586, Calycanthema, H. B. 30 inch. Cup and saucer variety. Pkt., 10c.

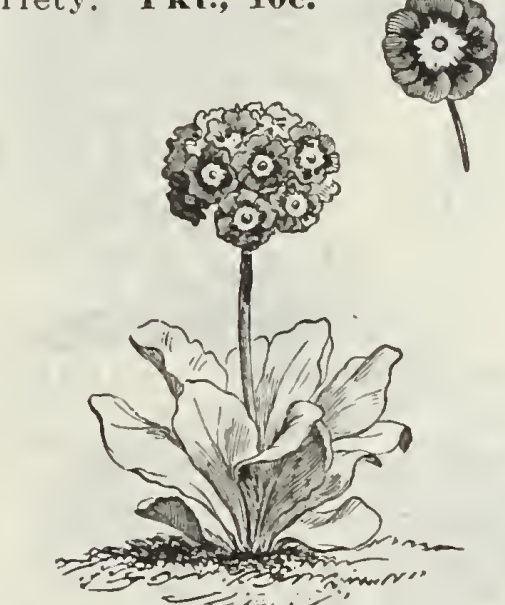

2548 A uricula, Alpine, mixed H. P., 6 inch. Grand bordel strain. Pkt., 10e.

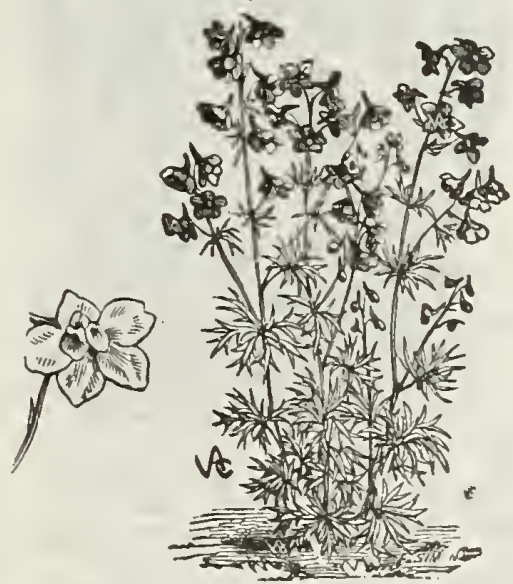

2652 Delphinium, grand, single, mixed, H. P., 36 inch. A stately border plant. Pkt. 10c. 
Dakota Improved Seed Co., Mitchell, S. D.

\section{Hardy Perennials and Biennials Continued}
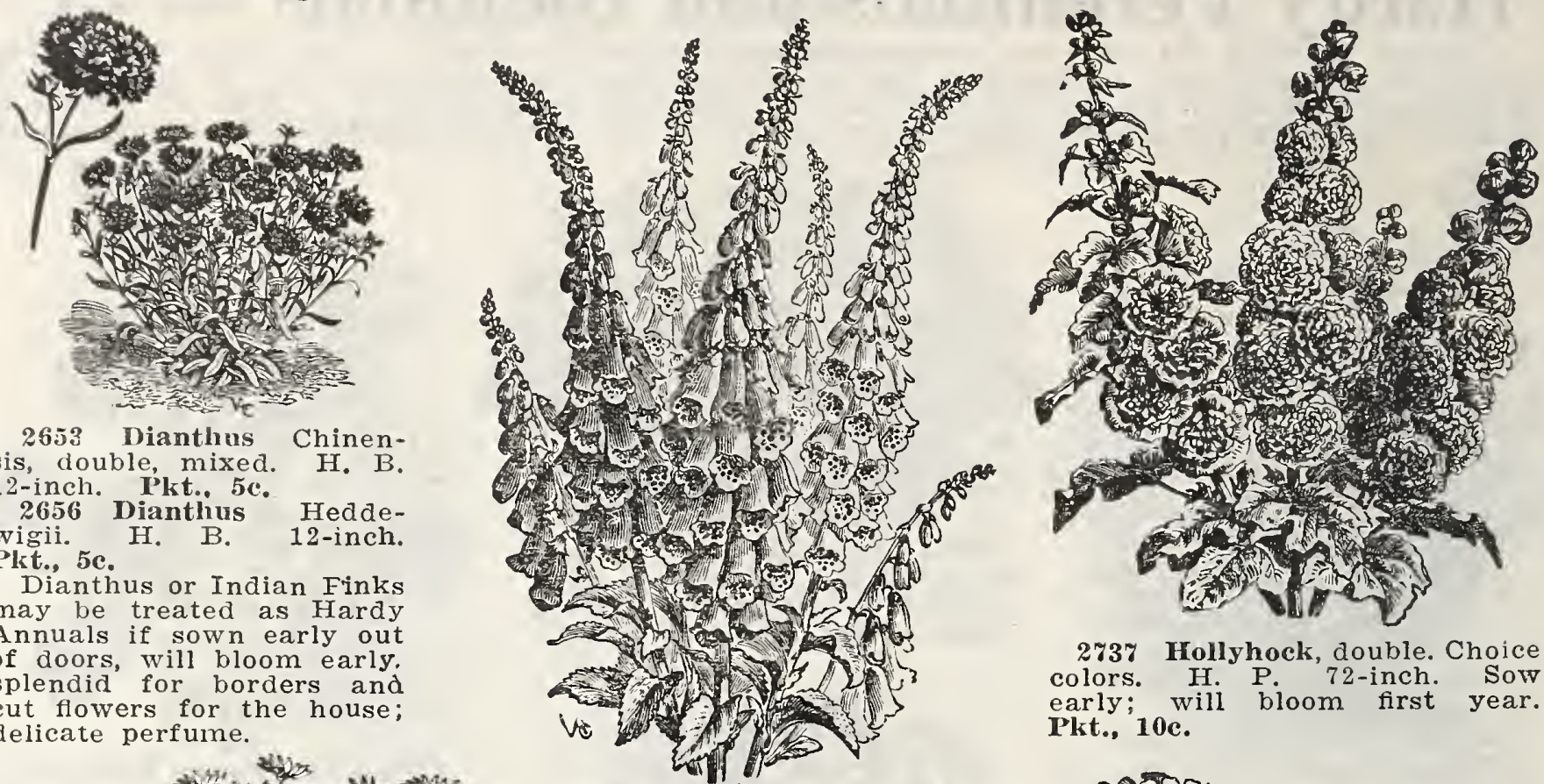

2653 Dianthus Chinen-

sis, double, mixed. H. B. 12-inch. Pkt.. 5c.

2656 Dianthus HeddePkt., 5c.

Dianthus or Indian Finks may be treated as Hardy Annuals if sown early out of doors, will bloom early. splendid for borders and cut flowers for the house delicate perfume.

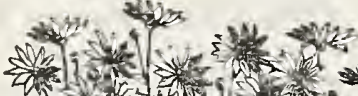

1.

2661 Digitalis monstrosa. Giant foxglove. H. P. 36-inch. Magnificent giant strain; fine colors. Pkt., 10c.

s. - 50 p

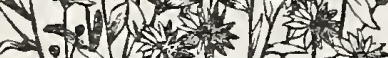
N.W.
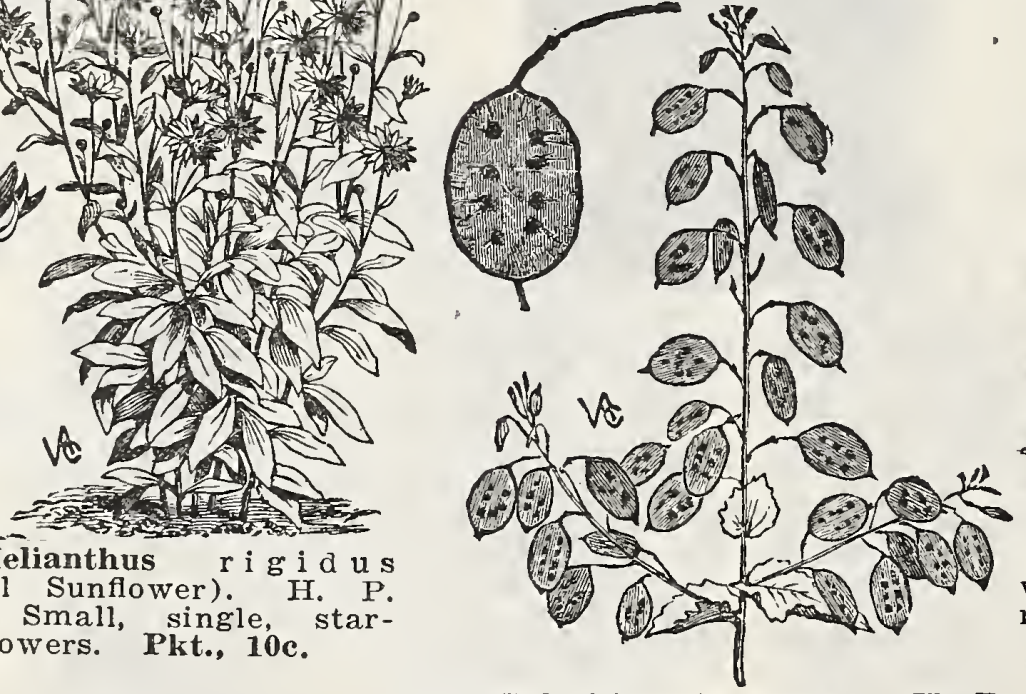

2738 Honesty, mixed $\mathrm{H}, \mathrm{B}$ 36 -inch. The silvery seed pods are very pretty. Pkt., 10c.

2732 Helianthus $r$ i g i d us (Perennial Sunflower). H. $P$. 72-inch. Small, single, starshaped flowers. Pkt., 10c.

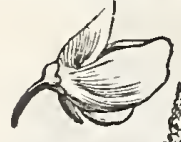

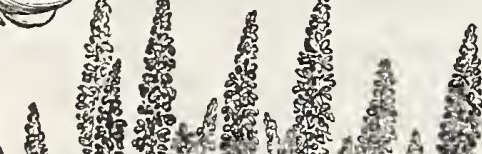

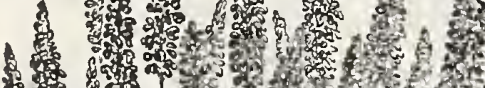

留

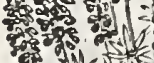

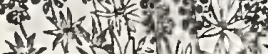

H 71 - 10 n

-

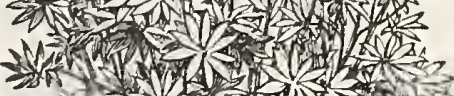

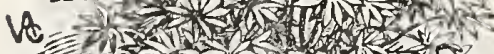

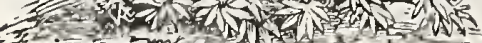

2795 Luminus, polyphyllus. H. P. 36-inch. Stately spikes of blue flowers. Pkt., 10c.

2660 Dianthus, Plumarius, single garden pink. H. P. 12-inch. The old-fashioned perennial pink. Pkt., 10c.

2691 Gaillardia, grandiflora. large flowers. Pkt., 10c.

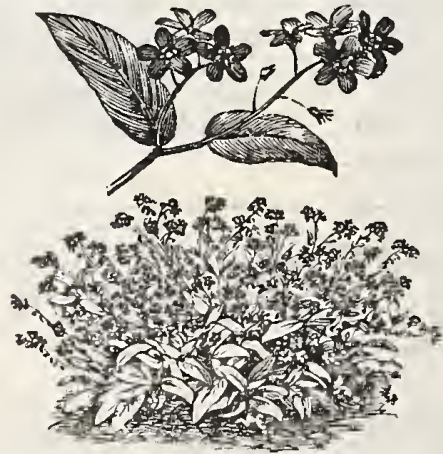

2842 Myosotis, dissitflora Perfection, blue. H. P. 6-inch. Pkt., 10c.

2843 Myosotis, palustris, blue. H. P. 6-inch. Pkt., 10c. The old fashioned Forget-Me-Nots are favorites with everyone. If sown in the spring and potted up in the fall, will bloom indoors all winter. Sown in June will bloom early following spring.
9737 Hollyhock, double. Choice colors. H. P. 72-inch. Sow early; will bloom first year. Pkt., 10c.

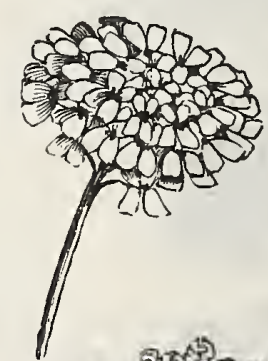

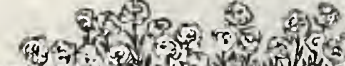
ReOH

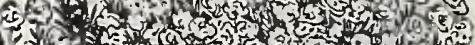

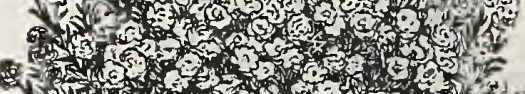

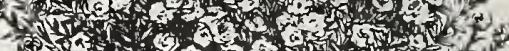
gen 2752 I b e r is, sempervirens, H. P. 6-inch. Perennial candytuft. Pkt., 10c.

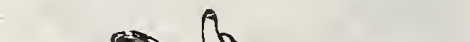

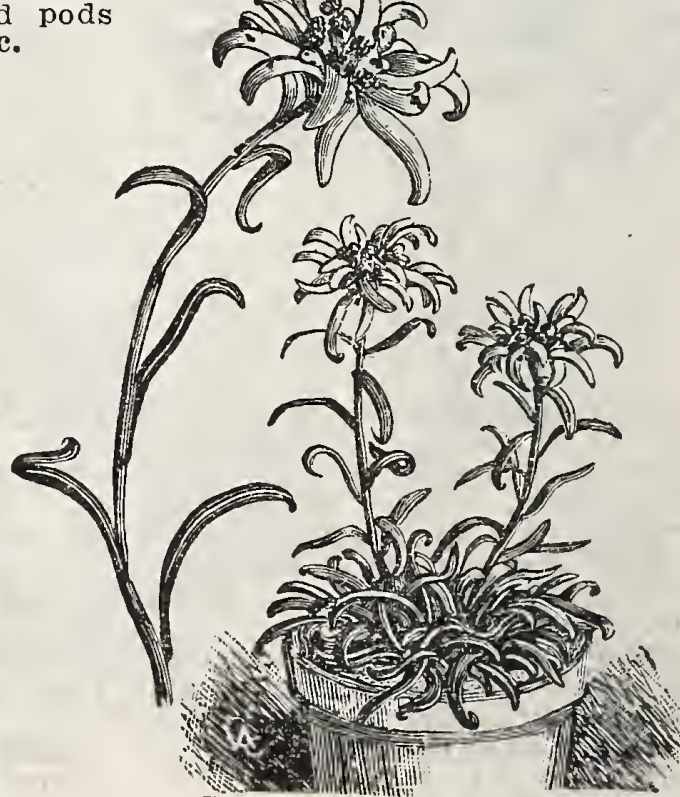

2676 Gnaphalium Leontopodium. H. P. 6-inch. Swiss Edelweiss.

Pikt., 10c.

Flowers Are a Never Ending Source of Delight 


\section{Hardy Perennials and Biennials-Continued}

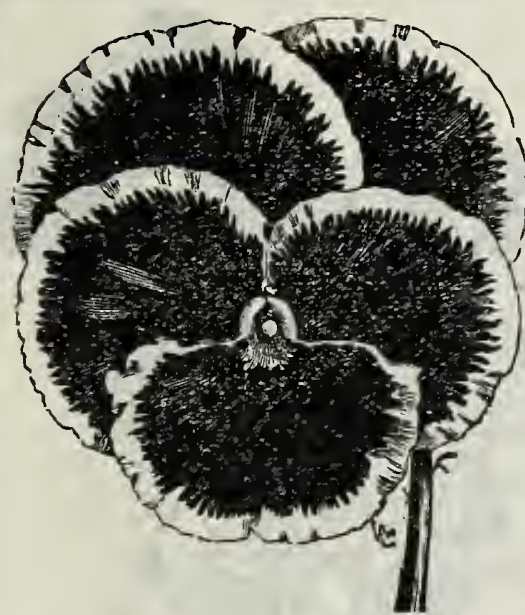

2881 Pansy, $B$ u g n o t's Giant, H. P., 6 inch. Beautiful large flowers. Pkt., 10c.

2887, Mixed colors, H. P., 6 in. Fine for general use. Pkt., 5c.

2888, Trimardeau, Giant, Mixed, H. P., 6 inch. Superb strain; enormous flowers. Pkt., 10e.

2924 Pyrethrum, aureum (Golden Feather), H. P., 6 inch. Beautiful plant for edging. Pkt., 10c.

2889 Papaver, bracteatum, Scarlet, H. P., 36 inch. The true perennial Scarlet Poppy. Pkt., 10c.

2890 Papaver, nudi-aule, Single, Mixed, H. P., 12 inch. The popular Iceland Poppy. Pkt., 10c.

2891 Papaver, Orientale, brilliant colors,

3013 Viola, Tufted, or bedding varieties, Mixeri, H. P. 6 inch. Sown early will bloom first year. Pkt., 10c.

3014 Viola, o d o rat a, Mixed, Sweet Violet, $H$. $P$. 6 inch. Choice mixture of best sorts. Pkt., 10c.

3019 Wallfower. Choice Double Dwarf, Mixed, H. P., 12 inch. Pkt., 10c.

3020 Wrllfower. Choice Single Dwarf, Mixed, H. P., 12 inch. Pkt., 10c.

If sown in July and given slight protection to hold the snow, will bloom early, in spring.

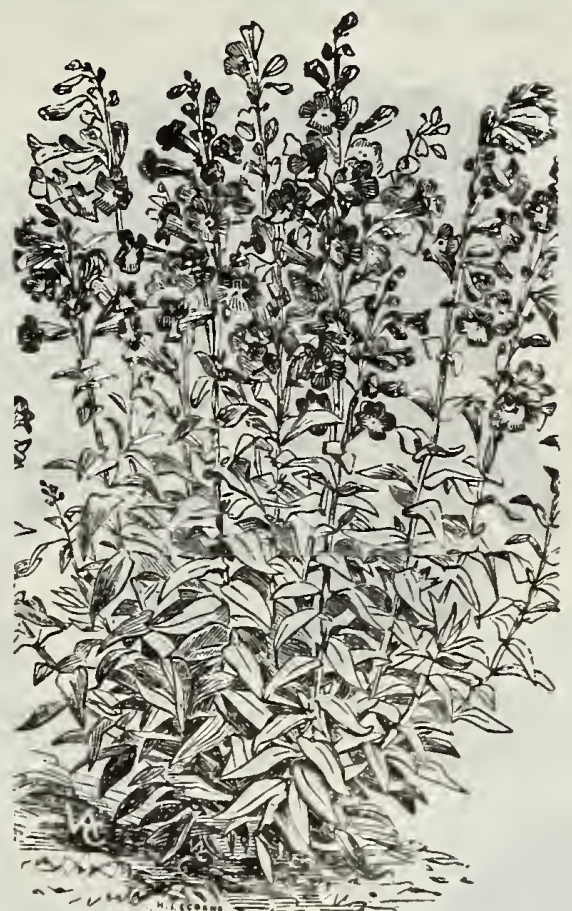

2893 Pentstemon, la $\mathrm{r}$ g e flowered hydrids, H. P., 18 inch. Will bloom first year from seed. Pkt., 10c.

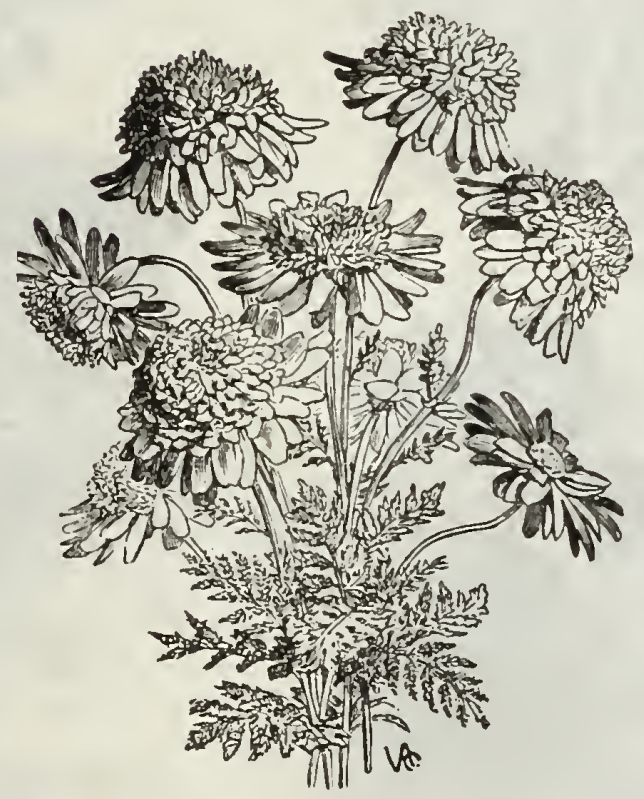

2925 Pyrethrum, roseum hybridum, Single, H. P., 24 inch. Beautiful Marguerite, like flowers. Pkt., 10c.

2926 Pyrethrum, roseum hybridum, Double, H. P., 24 inch. Splendid for early cut flowers. Pkt., 10c.

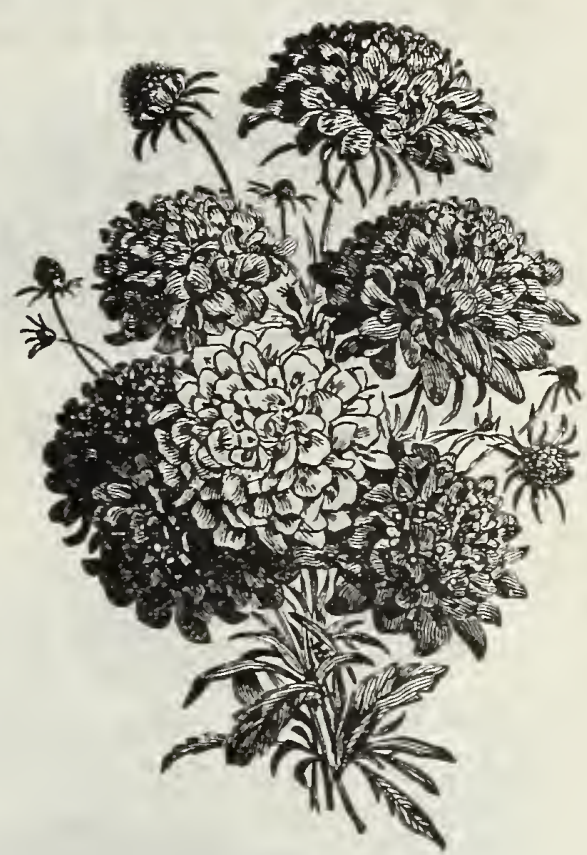

2956 Scabiosa, Caucasica Blue. H. P., 36 inch. Pkt., 10c.

2957, Caucasica alba, white, H. P., 36 inch. Pkt., 10c.

2959, Double large flowered, Mixed, H. P., 12 inch. Very handsome plants for perennial border. Sown early will bloom first year. Pkt., 10c.

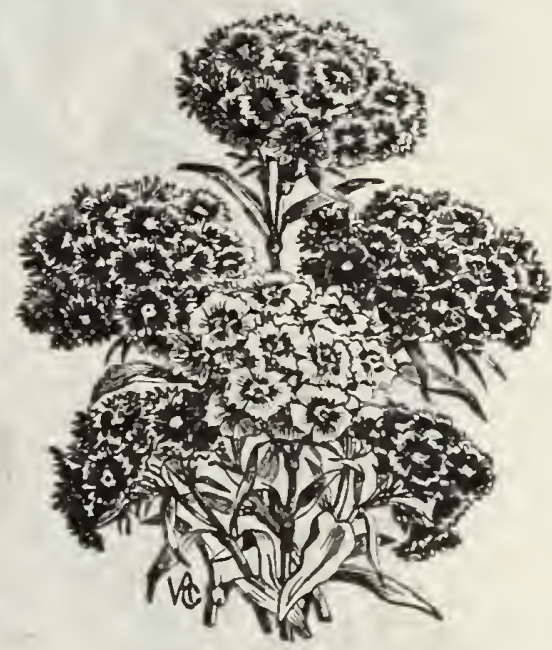

2984 Sweet William auricula eyed, H. P., 18 inch. Splendid for cutting. Pkt,, 10c.

$\mathbf{2 9 6 4}$ Shamrock, True Irish Variety, H. P., 6 inch. Sow this for St. Patrick's Day. Pkt., 10c.

2976 Stock, Brompton, Mixed, H. P., 6 inch. Sown early will bloom outdoors. Pkt., 10c.

Try our Pansies, they are superb 
Those marked "G. P" are perennials and "Ged from seed. should be sown indoors in small pots and when the plants are large enough to handle, transplanted into small pots singly and

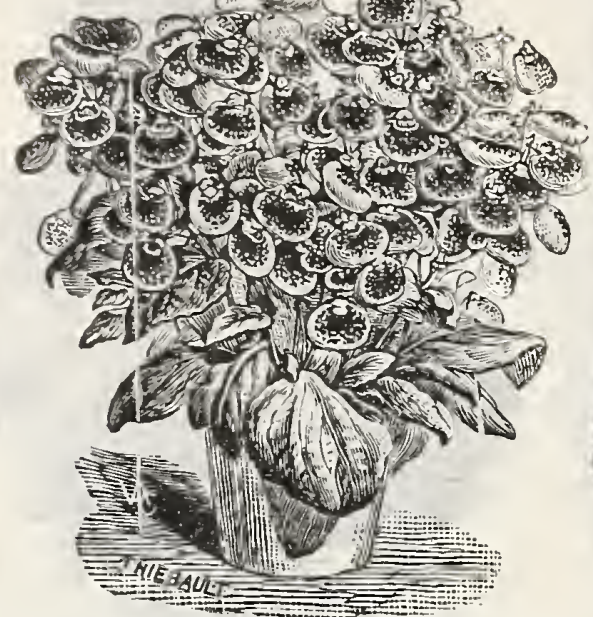

2566 Calceolaria, choice strain G. A., 18-inch. Spotted, blotched and self colored. Pkt., 25c.

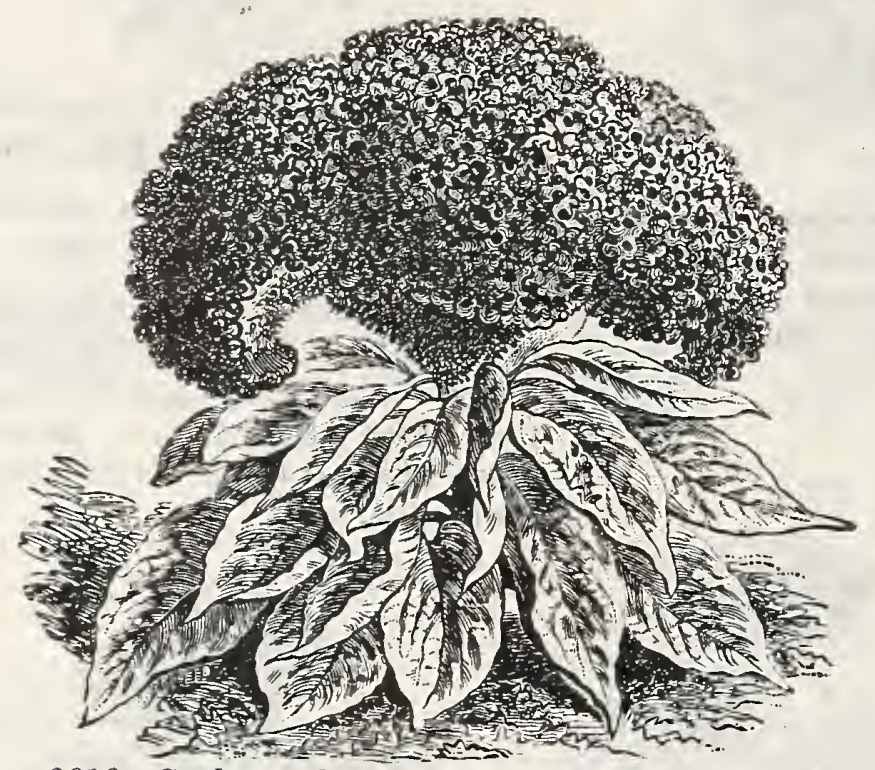

2616 Cuckscomb, Glasgow prize. G. A. $12-$ inch. Beautiful crimson comb. Pkt.. 1ne.

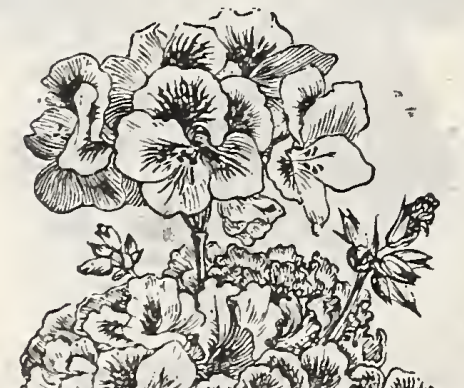

约, (1)

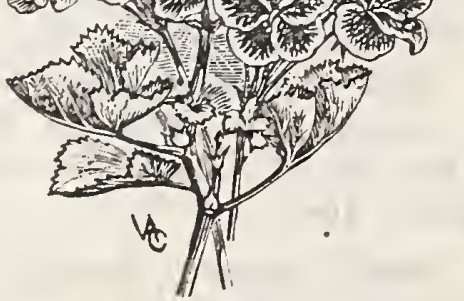

2892 Pelargonium, fancy G. P. 18-in. Splendid for window and house decoration. Pkt., 25c.

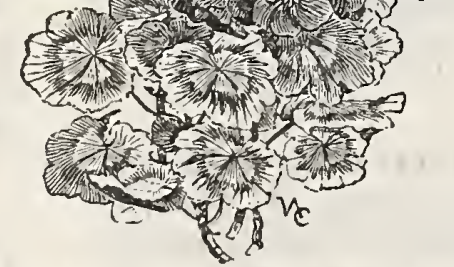

2694 Geranium, Zonale, choice, single, mixed. G. P. 18-inch. Easily lightful colors. Pkt., 25c. 2695 Geranium, Apple. $\mathrm{S}$ c e $\mathrm{n} \mathrm{t}$ e d odoratissima. G. P. 18-inch. Delicious

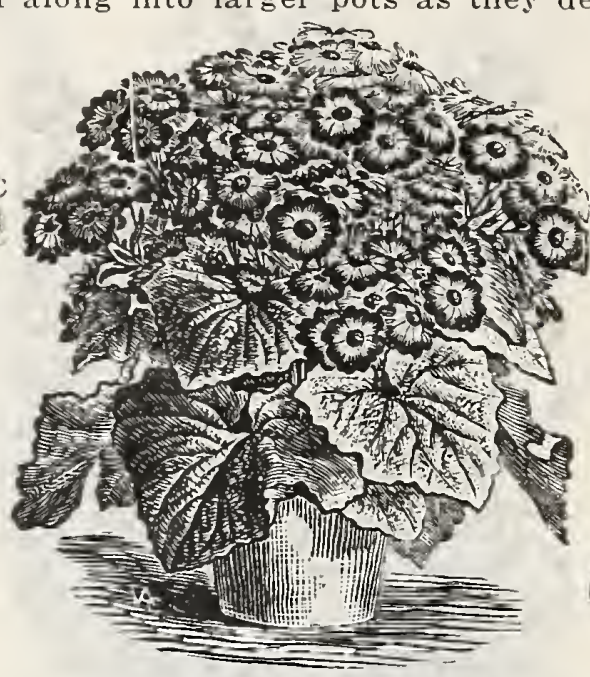

2607 Cineraria, hybrida grandiflora G. A., 18-inch. Gorgeous iflora G. A., 18-inct.
colors. Pkt., 25c.

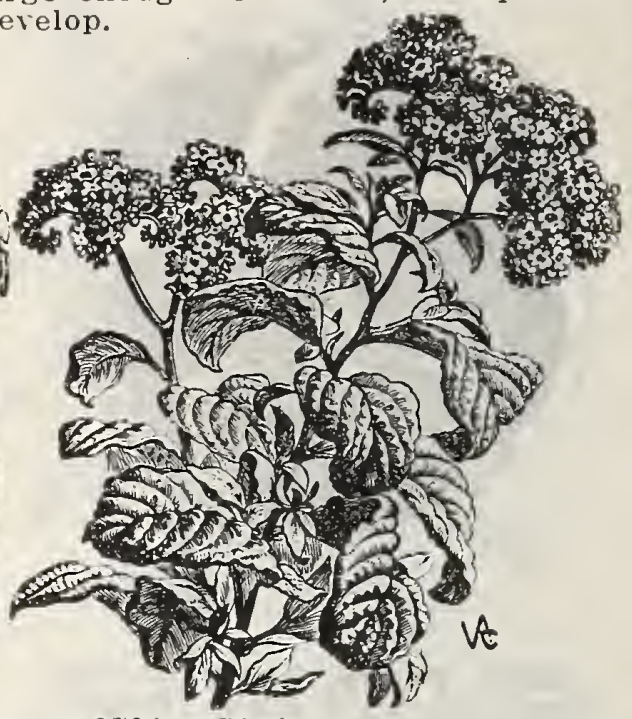

2734 Heliotropium, largest Howering giant mixed G $P$. 24 -inch. Heliotrope or Cherry
Pie Plant. Pkt., 10c.

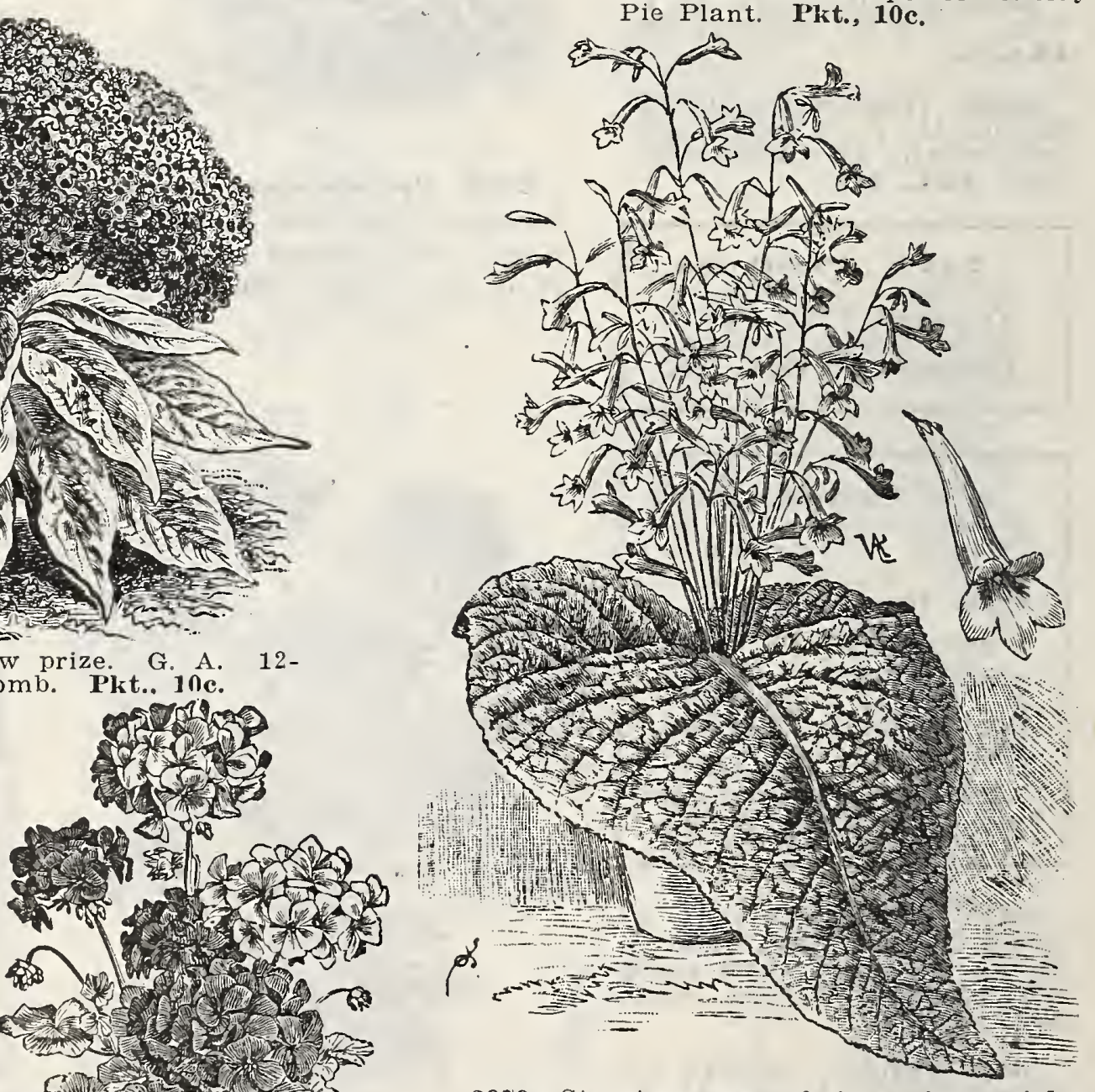
2979-Streptocarpus, choicest $\mathrm{h}$ y $\mathrm{b}$ r i d s.
G. P. 9-inch. Distinctive; easily grown house plant. Pkt., 15c.

\section{Various Plants}

2527 Asparagus, plumosus nanus. G. P. 18-inch. Asparagus fern. Pkt., 25c.

2528 Asparagus Sprengeri G, $\mathrm{P}$ 12-inch. rdeal basket plant. Plt., 15c.

2562 Begonia, tuberous rooted. Beautiful large G. A. 18-inch. Double flowers. Brilliant colors. Plkt., 15c.

2686 Eucalyptus, globulus (Blue Gum). G. P. 60-inch. Makes a nice pot plant. Antidote for "flu." Pkt., 10c.

2688 Fuchsia, a splendid variety. G. P. perfume. Pkt., 25c. 48-inch. Fopular house plant. Pkt., 25c. Grow your own house plants from Seed 


\section{Seeds of Plants Suitable for Greenhouse and House Decoration}
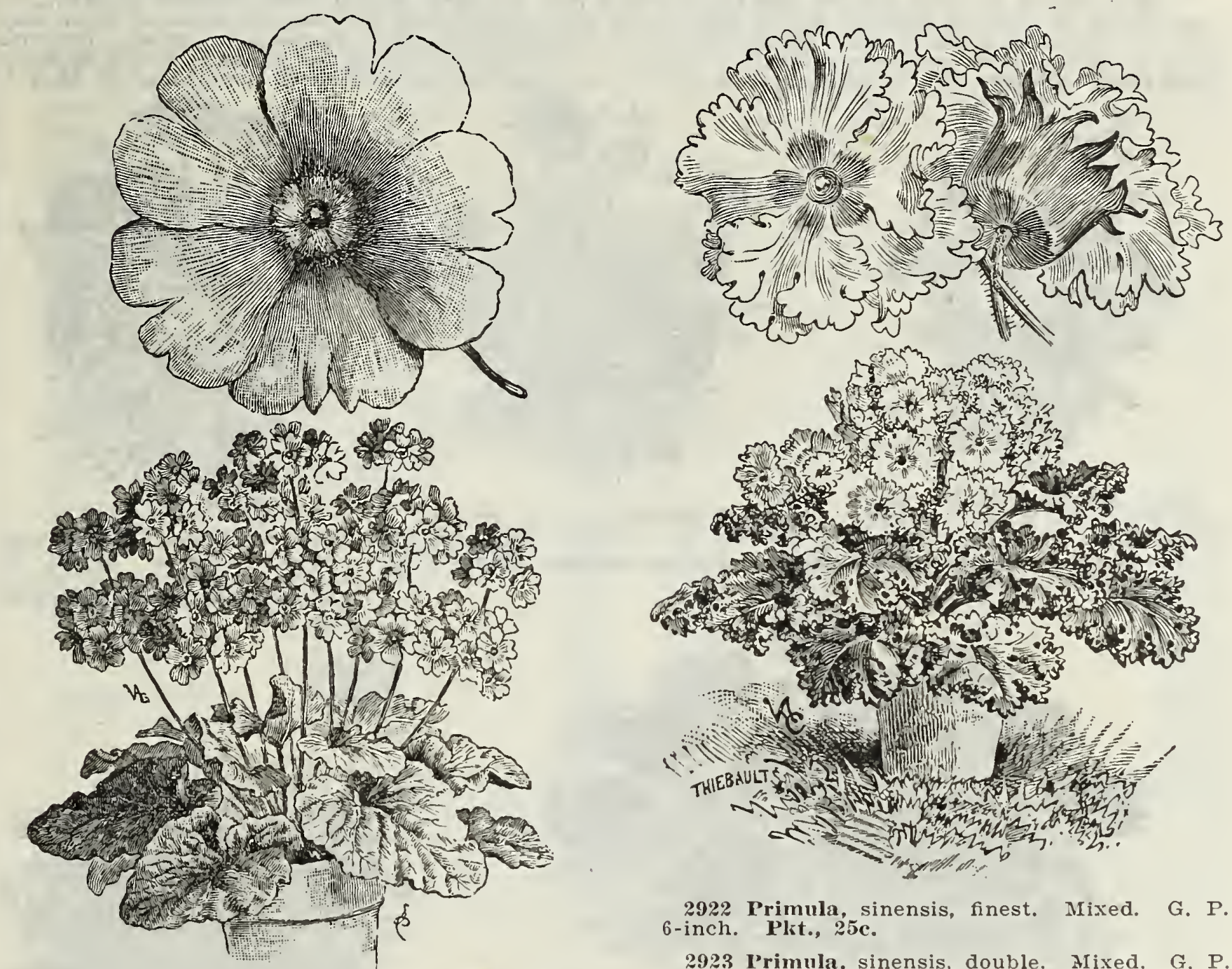

2922 Primula, sinensis, finest. Mixed. G. P. 6 -inch. Plit., 25c.

2923 Primula, sinensis, double. Mixed. G, P. 6-inch. Splendid for winter flowering in the 2921 Primula, obconica grandiflora hybrida. G. P. 12-inch. One of the best window plants. Pkt., 15c.

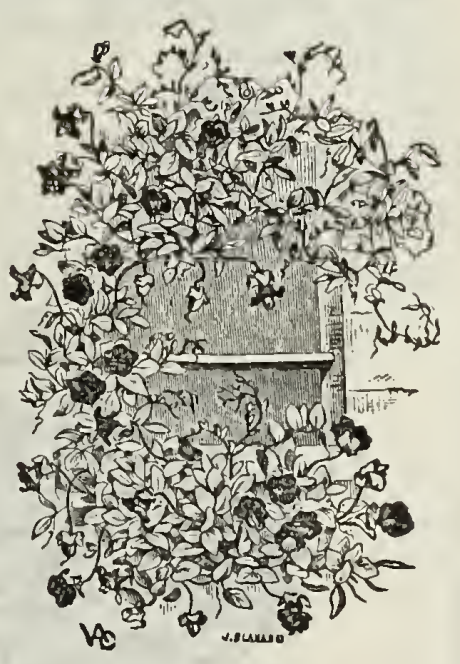

2615 Cobaea, scandens, Mixed. H. H. C. Makes a splendid house plant. Pkt., 10c.

\section{Various Plants}

2713 Grevillea Robusta (fern like). G. P. 36-inch. Beautiful house plant; easily grown from 2835 Mimosa, pudica (sensitive plant). G. A. 18-inch. A most interesting plant phenomena.

3011 Verbena, lemon scented. G. P. 36-inch. Deliciously perfumed leaves. Pkt.. 15c. You will have better plants and they will be more interesting 


\section{Half Hardy Perennials Easily raised from seed}

They should be sown indoors and transplanted into the open ground when weather is favorable and should be lifted in the Fall if it is intended to save them during the Winter. Some of these may also be treated as house plants. For instance, Mimulus moschatus, the old-fashioned Musk. Petunias may be also treated as house plants or may grow in the same manner as half hardy annuals. Half hardy climbers ( $H$. H. C.) may be treated in the same way as half hardy perennlals ( $H$. $H$. P.).

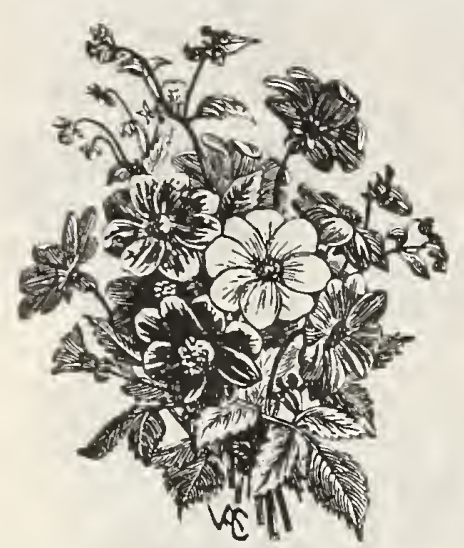

2645 Dahlia, single, large flowered. H. H. P. 48-inch. Plit., 10c.

Dahlias grow freet than from cuttings.

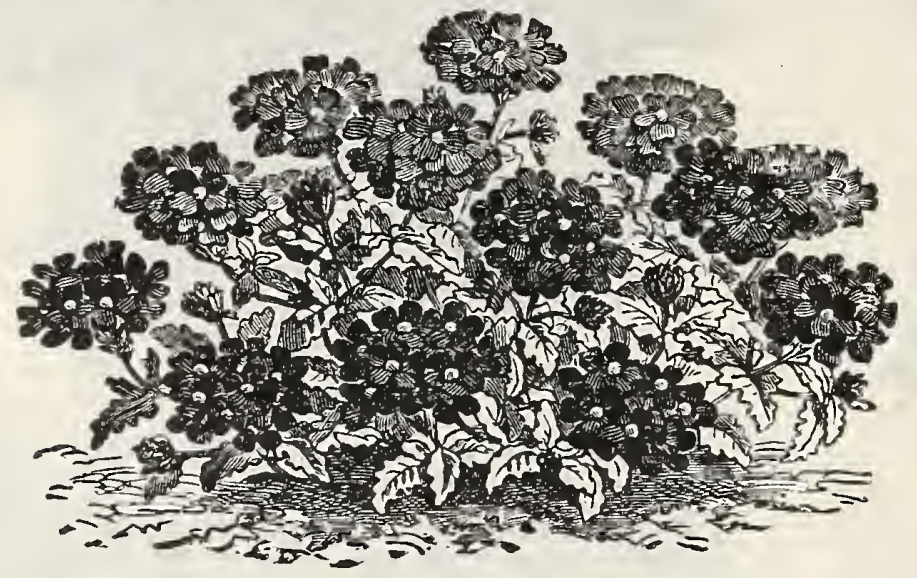

3009 Verbena, hybrida, mammoth mixed. $H . \quad H . P$. 6-inch. Enormous fowers; colors fine. Pkt., 10c.

\section{Lobelia}

2790 Alba White, H. H. P. 3-inch. Well known edging plant. Plkt., 10c.

2\%91 Speciosa Crystal Palace. H. H. F. 3-inch. Makes a nice pot plant. Plit., 10c.

2792 Tenuior, intense blue. H. H. P. 9 -inch. Lovely for pots or hanging baskets. Pkt., 10c.

\section{Petunia}

Nothing beats Petunias for giving a splendid show. They can be treated as Annuals, or if lifted and potted in the Fall, will keep all winter and bloom in early spring. 2895 Giants of California Mixed. H. H. P. 24-inch.

Pkt., 10c. Hybrida, mixed. H. H. P. 24-inch. Pkt., 10c.

2899 Hybrida grandiflora fringed, mixed. $H . \quad H . P$. 24-inch. Pkt., 10c.

2900 Hybrida, grandiflora, double fringed. Mixed.

H. H. P. 24-inch. Pkt., 25c.

3012 Verbena Venosa, purple and heliotrope. H. H. P. 12-inch. house or greenhouse; easily grown. Pkt., 25c.

2755 Ipomoea, Imperial Japanese. H. H. C. 96-inch These morning glories, if given protection from wind, will bloom beautifully all summer long. Pkt., 10c.

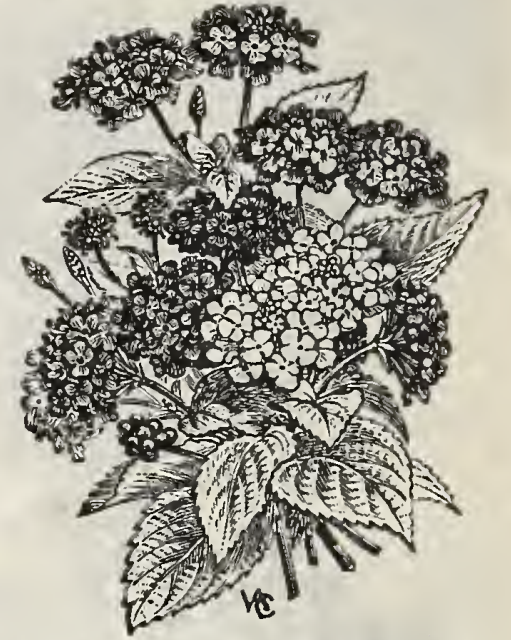

$27 \% 5$ Lantana, new dwart compact hybrids. H. H. F 9 -inch. Splendid pot plant: bloom outdoors all summer. Pkt., 10c.

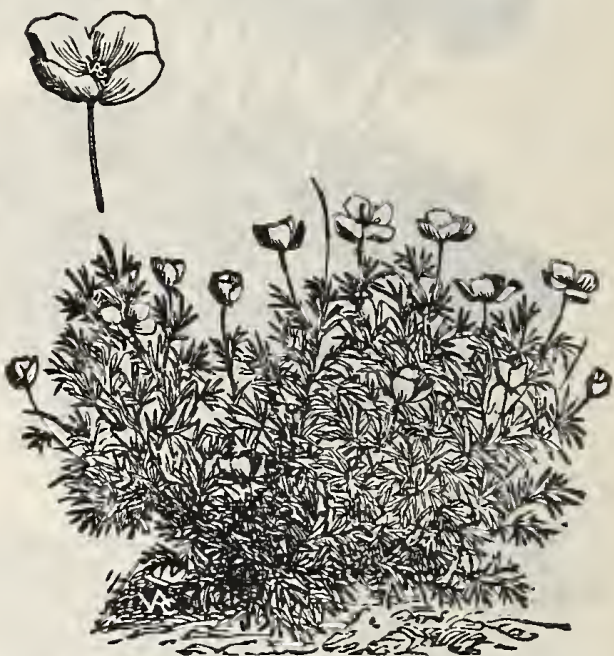

2\%42 Hunnemannia, fumariaefolia H. H. P. 24-inch. Makes a nice pot plant. Pkt., 10c.
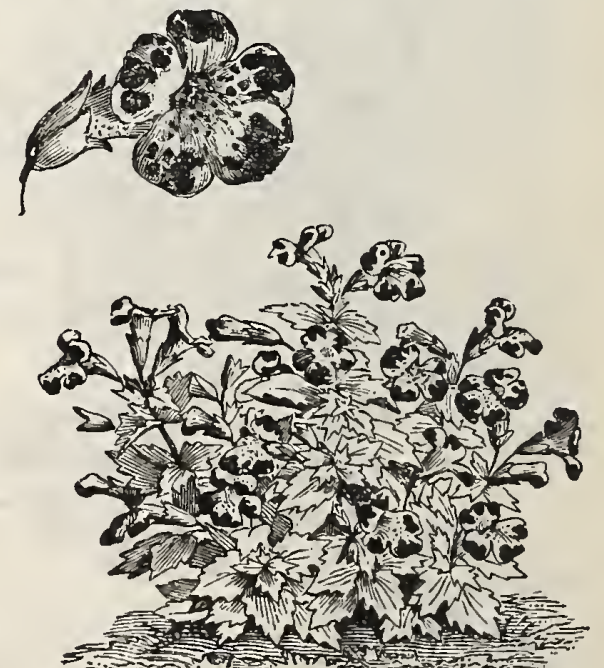

2837 Mimulus, Tigrinus, tigered and spotted. H. H. P. 6-inch. Giant Musk or Monkey Flower Pkt., 10c.

2836 Moschatus (Musk).. H. H. $P$. 6-inch. Old fashioned sweet scented Musk. Pkt., 10c.

\section{Our petunias are the very best}


To insure prompt attention address all orders to the firm, not to individuals. Use order sheet in front of catalog .

CDTCT T DDTCD. CTITTM Prices are effective January 1st, 1922 and are based on

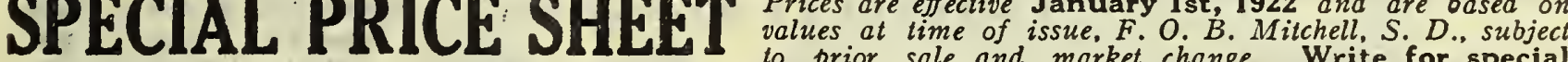
prices on large quantities. All seeds are sold on the basis of the Disco Guarantee, printed on the inside back page cover of the 1022 Catalog. We expect prices will advance, and recommend early ordering. If no Agen at your station, add sufficient to prepay freight or express. If you remit too much, surplus will be promptly refunded. If required by parcel posi, your Postmaster will tell you in what zone from Mitchell you are located so that you may include correct posiage with your remittance.

Our Co-operative plan: In view of high freight rates we are anxious to co-operate with our customers to enable them to combine together in a co-operative way and make up carload shipments. This not only saves freight. but also insures more prompt and safe delivery, as in carload lots the bags are loaded into the cars at our warehouse and go right through to destination without change. To enable our customers to do this, we will reserve orders at current prices, when orders are received. on payment of $25 \%$ of the value, the balance to be paid before shipment is made. We make this concession to encourage co-operative orders and early ordering. This will apply only on orders received before March I5th, 1922, and they must be completed not later than A pril 5th, 1922. Get together! Co-operate with a firm that has given you good service in the past and aims to serve you better in the future. Should prices have changed when your order is received, if lower, we will refund balance; if higher, we will either reduce your order to the amount remitted, or ship C. $O . D$. for the balance, as you prefer.

ALFALFA. Bountiful crops are being harvested all over the United Stales and Canada from fields sown with DISCO ALFALFA SEED. DISCO Hardy Alfalfa is a household word with successful Alfalfa growers.

Current Prices January 1st, 1922. F. O. B. Mitchell, S. D. No Cartage Charges. Special Bags Weighed In Free.

ALFALFA, 60 lb. per bushel.

akota Grown, Common,

Sunshine Brand $\$ 16.00$

$\$ 8.50$

25 Lbs. 1 Lb.

100 Lb. Price Packed in Price

Dakta

9.50

10.50

DISCO Brand. 20.00

13.50

Rezistered Disco No. 26............. 26.00

$\begin{array}{rr}4.50 & \$ .21 \\ 5.00 & .23\end{array}$

Equals per Bags per

"

15.50

$5.50 \quad .25$

$\begin{array}{ll}7.00 & .31 \\ 8.00 & .35\end{array}$

14.00

$26.00 \quad 13.50$

“ “ 89

26.00

13.50

DIsCo Grimm .................. 40.00

20.50

$7.25 \quad .32$

$7.00 \quad .31$

$7.00 \quad .31$

$10.50 \quad .45$

$11.75 \quad .50$

$45.00 \quad 23.00$

Baltic

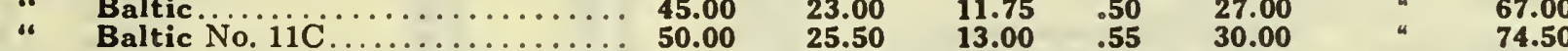

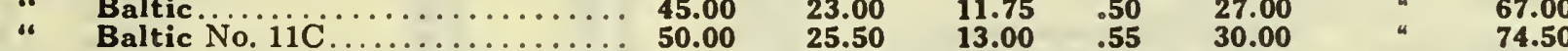

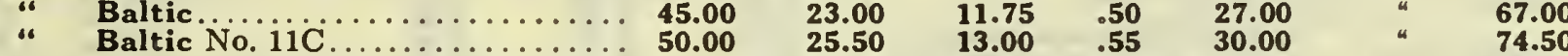

Bushel Containing Bag

$\$ 9.60$ 150 lbs. $\$ 23.50$

12.00 " 29.50

$15.60 \quad$ " $\quad 38.50$

$18.00 \quad 44.50$

16.20 " 40.00

15.60 \& 38.50

$15.60 \quad 38.50$

$\mathbf{2 4 . 0 0 \quad 5 9 . 5 0}$

$27.00 \quad 67.00$

We screen our Registered Alfalfas very very rigidly and this necessitates the elimination of a considerable quantity of really good seed, which owing to the fact that it is not perhaps just as plump as it might be it is separated from our best grades of Registered Seed. This seed being of a very hardy character is wiel adapted for renovating old pastures or for sowing with small grains as a fertilizer. If interested write for samples and prices, stating quantity required and for what purpose.

We had the misfortune to have some Sweet Clover mixed with one lot of our Disco No. 28 Alfalfa. Tested carefully for purity we find it runs about $12 \%$ of Sweet Clover otherwise the seed is $\mathrm{O}$. K. We will sell at a sacrifice. If interested write for sample and price, stating quantity required

CLOVERS, $60 \mathrm{lb}$. per bushel.

Sweet-Hulled and Scarified.

Hubam-New Annual..

Write for special price on large quantities

White Blossom-DISCO Brand........\$10.00

White Blossom-Emerald Brand ........ $\$ \mathbf{9 . 5 0}$

Yellow Blossom-DISCO Brand........ 11.00

Medium Red-DISCO Brand .......... 23.00

" " -Emerald Brand.

Mammoth Red-DISCO Brand

Alsike or Swedish-DISCO Brand - Emerald Brand.

22.00

24.00

23.00

21.00

hite or Dutch-DISCO Brand

50 Lbs. 25 Lbs. 1 Lb $\$ 1.00$

100 Lb. Price Packed in Price

Equals per Bags per

NOCULATING CULTURE-1/2 bu. size, $60 \mathrm{c}$; $1 \mathrm{bu}$. size, $\$ 1.20$; sufficient for $300 \mathrm{lbs}$., $\$ 5.75$. If required by mail add extra for postage.

DAKOTA GROWN SEED CORN-Shelled and Graded 56 lbs. per bushel.

Yellow Dent Varieties.

Riverview Special.

Minnesota 13 .

$\$ 5.50$

$\$ 3.00 \quad .15$

5.25
6.00

12.00

11.50

12.50

12.00

11.00

2.85

3.75

$6.25 \quad .28$

$6.00 \quad .27$

$6.50 \quad .29$

$6.25 \quad .28$

5.75 .26

$5.50 \quad .25$

Bushel Containing Bag

10 Bushels 5 Bushels

or More or More

Early Murd

per Bushel per Bushe

Disco Pride.

$\$ 2.00$

1.85

$\$ 2.05$

Pride of the North

Wimples.

White Dent Varieties.

Disco 90 Day........

Silver King.

Northwestern Dent.

Disco Flint Corn.

Disco White.

Gehu Yellow.

Disco Squaw (Rainbow)

King Philip Red.

Longfellow Yellow.

Disco Fodder Corn.

Early Dent....

1.75
2.25

2.00

1.70

1.90
1.80

2.30

2.05

1.80

$\$ 6.00$

5.70

6.60

13.80

13.20

14.40

13.80

12.60 150 lbs.

1.70

1.70

1.80

CHARGE

FOR

1.65

1.70

Price $\begin{array}{lll}1 \text { Bushel } & \begin{array}{c}\text { Bags } \\ \text { Containing }\end{array} & \begin{array}{c}\text { per } \\ \text { Bag }\end{array} \\ \mathbf{\$ 2 . 2 0} & 21 / 2 \mathrm{Bu} . & \mathbf{5 . 4 0}\end{array}$

$\$ 2.20$

2.00

1.90

2.50

2.20

1.85

$\$ 14.50$

13.75

$\mathbf{1 6 . 0 0}$

32.50

35.50

$\mathbf{3 4 . 0 0}$

31.00

29.50
74.50

Evergreen Sweet ( 46 ibs.)

BAGS

1.90

1.85

1.80

1.85

$\begin{array}{ll}1.80 & 1.85 \\ 1.70 & 1.75\end{array}$

1.70

1.75

1.70

1.80

1.80

2.00

1.85

1.90

1.90

1.90

1.00

1.05

1.00

1.05

.95

1.97

2.00

4.90

4.65

5.90

5.40

4.50

4.65

4.50

4.75

4.50

4.50

4.65

4.65

2.65

2.65

5.15

DAK OTA IMPR OVED SEED CO., Mitchell, S. D. the corn Palace 


\section{Q iscos Special Price Sheet GUARANTEEDSEEDS FOR EARLY ORDERS}

Subject to Prior Sale and Market Change. Read Other Side Before Ordering.

Current Prices January 1st, 1922.

F. O. B. Mitchell, S. D. No Cartage Charges

Bags Weighed in Free

DISCO SELECTED MILLETS, 50 lbs. per bu.

Western Golden.

Siberian.

Golden or Liberty (German)

Hog or Broom Corn.

Bags
Are
Free

Early Fortun

Japanese or Billion Dollar Grass (36 lbs.).

DISCO SELECTED GRASS SEEDS.

Timothy-DISCO Brand. .

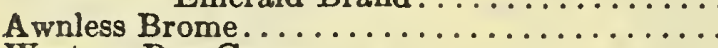

Western Rye Grass.

Meadow Fescue or English Blue............

Red Top (Solid Seed).

Kentucky Blue

Canadian Blue

Perennial Rye Grass

Crested Dog's Tail ...

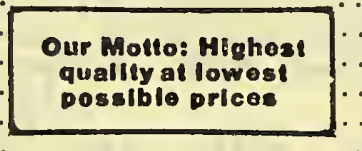

ISCO SELECTED MIXTURES.

Disco Permanent Pasture Mixture......... 16.00

" " Meadow Mixture..............

Timothy and Alsike, Mixed

Timothy and

Disco Annual Hog Pasture Mixture.

DISCO FORAGE AND SOILING CROPS.

Rape, Dwarf Essex, Genuine Holland Grown No. 1

Sunflower, Russian Giant. .

Disco Early Amber Fodder Cane............

Amber Sorghum Cane.

Sudan Grass ....... Remember we make . .

Feterita.......... no charge for bags.

Milo Maize......... Weighed in FREE.

DISCO SELECTED SEED GRAINS.

Speltz, 40 lb. per bushel..................

Soy or Soja Beans, all strictly Northern Grown, 60 lbs. per bushel.

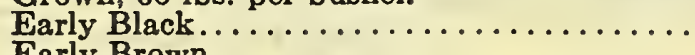

Early Brown.$\ldots \ldots \ldots \ldots \ldots$

Japaneat, 48 lbs. per bushel.

Silver Hull.

00 Lbs.

$\$ 2.50$

2.75
2.50

2.75

2.50

2.75

6.00

7.00

6.50
12.00

10.00

25.00

25.00

50.00

40.00

15.00

50.00

20.00

50 Lbs. 25 Lbs.

00 Lb Price Packed in Special

Equals per Bags

Bushel Containing Baz

$\$ 1.40 \$ 0.85$

$\begin{array}{r}1.50 \\ \hline\end{array}$

1.40

1.50

1.40

1.50

3.25

3.75

3.50
6.25

6.25

5.25

12.75

12.75

25.50

20.50

7.75

25.50

10.25

$\$ 0.85$
.90

.85

.90

.85
.90

1.90

2.00

1.90

3.25

2.75

6.50

6.75

13.00

10.50

4.00

13.00

5.25

8.25

8.25

6.75

6.75

$\mathbf{3 . 0 0}$

4.25

4.25

3.50

1.65

9.00

4.75

3.75

2.50

3.00

5.00

5.00

3.00

3.50

3.50

1.75

2.75

2.75

1.75

2.00

2.00

1.80

1.00

2.00

1.50

1.00

1.15

1.15

.60

$\$ 1.25$

1.38

1.25

1.38

1.25

1.38

2.16

3.15

2.92

1.68

1.40

$\cdots \cdots$

$\ldots \ldots$

$\cdots \cdots$

.....

$150 \mathrm{lbs}$

$\$ 3.65$

\begin{tabular}{l}
4.00 \\
$-\quad 3.65$ \\
\hline
\end{tabular}

$4 \quad 4.00$

3.65
4.00

8.75

135 lbs. $\quad 9.30$

100 lbs $\quad \mathbf{8 . 7 0}$

10.00

" $\quad 25.00$

112 lbs. 55.00

200 lbs. 44.00

100 lbs. $\mathbf{5 0 . 0 0}$

20.00

$\ldots \ldots$ " $\quad 16.00$

$\ldots \ldots$... 16.00

..... 135 lbs. 17.35

…. 100 lbs. $\quad \begin{array}{r}\mathbf{1 7 . 3 5} \\ \ldots .50\end{array}$

..... 220 lbs. $\quad 18.00$

$\ldots \ldots$... $100 \mathrm{lbs} .7 .00$

$\ldots \ldots . \quad 140$ lbs. $\quad 4.00$

..... $\quad 125$ lbs. $\quad 6.10$

.... 100 lbs. $\quad \mathbf{5 . 0 0}$

…. 3.00

$\ldots \ldots$

Per Bu.

3.50

$.72 \quad 1.80$

$\begin{array}{lll}9.00 & 4.75 & 2.50\end{array}$

9.00

4.75

2.50

2.75

5.00

2.75

1.50

When you buy DISCO SEEDS you are buying the best. The best is always the cheapest in the end.

Barley, 48 lbs. per bushel.

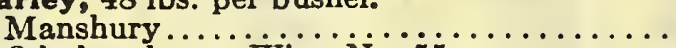

Oderbrucker or Wisc No. $55 \ldots \ldots \ldots \ldots \ldots$

Improved White Hulless (60 lbs.)........

Flax, 56 lbs. per bushel.

N. D. Wilt-resistant.

Oats, 32 lbs. per bushel.

New Disco No. 22 Hulless-1 lb., 35c; 2 lbs.

$65 c$; 5 lbs., $\$ 1.50$; write for prices on larger quantities.

Swedish Select.

Victory.....

Sixty-Day.

Ryo, 56 lbs. per bushel

Write for spoolal
prices on large
quantilles
quantilies

\begin{tabular}{ccc}
10 Bushels & 5 Bushels \\
or More \\
per Bushel \\
$\$ 0.90$ & $\begin{array}{c}5 \text { More } \\
\text { or Bushel } \\
\text { per } \\
\$ 0.93\end{array}$ \\
\hline & .90 & .93 \\
1.80 & 1.83 \\
\hline & 2.40 & 2.45
\end{tabular}

1.50

5.40

150 lbs. $\quad 13.00$

13.00

2.40

100 lbs. $\quad 5.00$

2.40

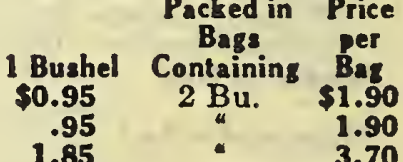

2.50

$\mathbf{5 . 0 0}$

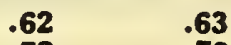

.72

.63

.73

$\cdots$

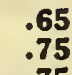

$21 / 2 \mathrm{Bu}$.

1.58

1.80

1.58

1.60

3.95

Amber Winter-Write for Prices.

1.57

4.00

1.95

1.70

2.20

4.50

4.95

$\ldots$

4.60

5.10

4.10

2.00

1.75

2.25

0.10

4.88

4.25

5.50

Winter Wheat, 60 lbs. per bushel.

Nurkey Red-Write for Prices.

old Peas, 60 lbs, per bushel.

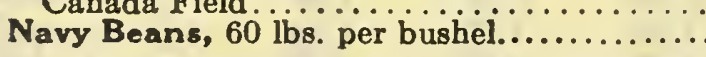

NORTHERN GROWN SEED POTATOES.

Write for Price on larger quantities.

Early Ohio.

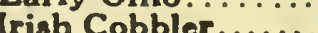

.....

$\mathbf{3 . 5 0}$

2 Bu. $\quad \begin{aligned} & 7.00 \\ & 4.00\end{aligned}$

Cyclone Broadcast Seeders, Complete ready to use, $\$ 2.00$ each. If ordered with seeds value $\$ 10.00$. Special price $\$ 1.75$.

DAKOTA IMPROVED SEED CO., Mitchell, S. D. 


\section{Poultry Supplies and Sundry Requisites}

\section{For Garden and Farm}

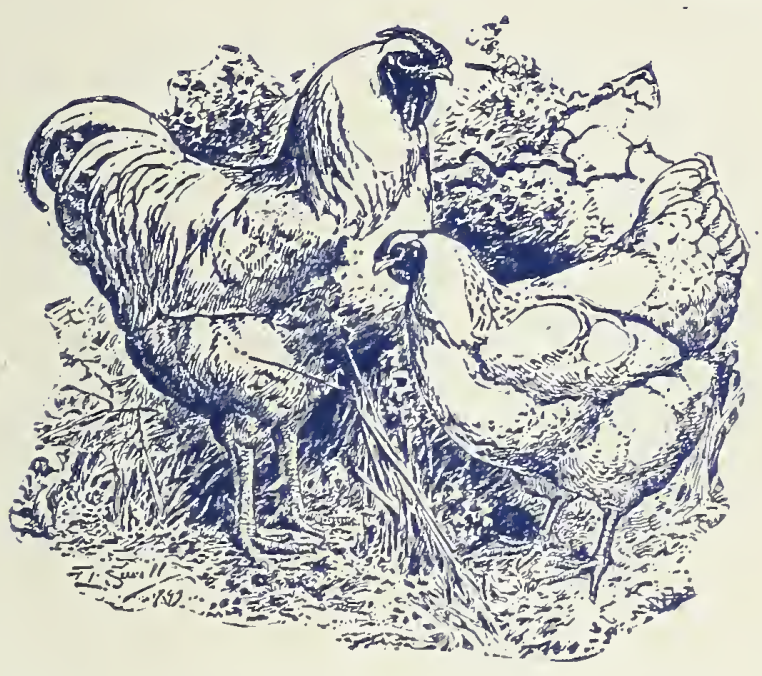

We are headquarters for poultry supplies; also miscellaneous requirements for Farm and Garden. We have not space to give descriptions of our full line. Write us for prices on anything you require. Your inquiry will receive prompt and courteous attention.

BABY CHICK STARTER-A wholesome starting food which will keep chicks healthy and cause them to make rapid growth. Suitable for feeding for the first three weeks. May be given to them as soon as they are 36 hours old, 50 1b. bag, \$1.75; 100 lb. bag, \$3.35.

CHICK FEED-May be fed to chicks after they are three weeks old and contains the proper ingredients balanced in the right proportions to promote rapid growth, and strong healthy chicks. 50 1b. bag, \$1.70; 100 $1 \mathrm{~b}$. batg, \$3.30.

ALFALFA MEAL-Made from new crop, pea green, kiln-dried hay. May be mixed in with the mash or moistened slightly with hot water and allowed to steam slightly before feeding. Alfalfa meal is also very useful aside from this as a litter for the brooder or chick pen as it is an excelient absorbent and will not injure the baby chicks if they eat it. 50 11). b:15, \$1.50; 100 lb. bag, $\$ 2.85$.

FEED MILIET. 50 11). bag, $\$ 1.60 ; 10011$. bag, \$3.00.

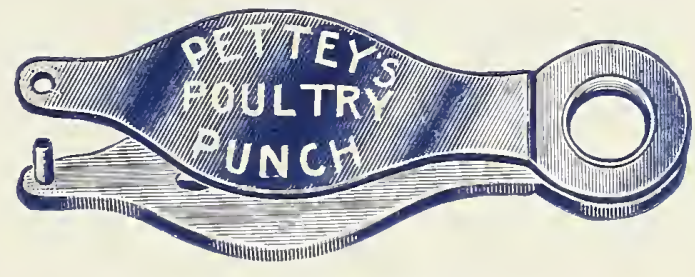

$35 \mathrm{c}$ each postpaid
CRUSHED OYSTER SHELL-Laying hens require crushed oyster shell for the purpose of encouraging the formation of shells. A hopper with oyster shells should always be within reach, particularly during the winter months or when the poultry are confined, many poultry raisers find it a profitable investment to feed oyster shells the year around. 50 lb. bag, S5e; 100 lb. bag. $\$ 1.60$.

GRIT-Poultry should be constantly supplied with sharp material to grind their food. Poultry size 50 lb. bag, \$1.00; $1001 \mathrm{~b}$. bas, \$1.85; chick size 50 lb. bag, $\$ 1.00 ; 100$ 1b. bay, $\$ 1.85$.

GRANULATED BONE-Made from fresh. green bones, which have the moisture. grease, etc., extracted, leaving nothing but phosphate of lime and protein. Medium. 50 1b. bag, $\$ 2.60 ; 100$ 1b. bas, $\$ 5.00$; fine, 50 1b. b:ag, \$2.60; 100 lb. bag, \$5.00.

CHARCOAL-Should be left in a hopper exposed so that poultry will have free access to it at all times. It is one of the best correctives and helps perhaps more than anything else to maintain good health in the flock. Medium, 50 1b. b:1 s, \$2.60; 100 1h. b:15, \$5.00; Fine, 50 1b. bag, $\$ 2.60 ; 1001 \mathrm{~b}$ bag, \$5.00.

MEA'T SCHAPS-Rich in protein, material which makes muscle and lean meat. Finest quality. 50 1b. bag, \$2.65; 100 1b. bag, \$5.00.

FEED SUNFLOWER. 50 1b. bag, \$3.35; 100 1b. bag, \$8.50.

CORN FOR MOPPING. Per lb., be; per 100 lbs., \$.50.

BIRD SEEDS-Finest recleaned. Hemp. per lb., 15e; Canary, per lb., 15e; Hird Millet, per lb., 7e; Parrot food, per lb., 10e: Hird Rape, per lb., 20e; DISCo Bird Mixture, per $1 \mathrm{~b} ., 20 \mathrm{c}$

Write for prices on Incubators, Cultivators, Seed Sowers, Corn Testers, Fertilizers, etc. Above prices are F. O. B. Mitchell S. D., and subject to narket changes.

\section{The QPiscos Guarantee}

The DAKOTA IMPROVED SEED COMPANY guarantees the seed it sells to be as represented as to quality and germination. All our seeds are tested and nothing that does not reach a high standard is distributed. In spite of this, we stand ready to replace or refund the money paid for any seeds sent out by us, which upon arrival are not entirely satisfactory. We do not insure a crop from seeds purchased either as to description, productiveness or any other matter, because of the many factors which influence a crop and which are entirely beyond our control. All sales are therefore based on the understanding that the liability of the company shall in no case exceed the price paid for the seed.

\section{Postpaid}

Postage paid on all Vegetable and Flower Seeds unless otherwise stated. Orders for Alfalfa, Corn, Grasses and everything else listed in our book if required by parcel post must have postage added. 
